\title{
IMPLEMENTATION OF SUSTAINABLE MANAGEMENT PRACTICES AT TWO CALIFORNIA CENTRAL COAST VINEYARDS \\ AND THEIR EFFECTS ON SOIL FERTILITY
}

\author{
A Thesis \\ Presented to \\ the Faculty of California Polytechnic State University, \\ San Luis Obispo
}

\begin{abstract}
In Partial Fulfillment
of the Requirements for the Degree

Master of Science in Agriculture with

Specialization in Soil Science
\end{abstract}

by

Dawn Michelle Stimson

November 2009 
Dawn Michelle Stimson

ALL RIGHTS RESERVED 


\section{COMMITTEE MEMBERSHIP}

TITLE: Implementation of Sustainable Management Practices at Two California Central Coast Vineyards and Their Effects on Soil Fertility

AUTHOR: Dawn Michelle Stimson

DATE SUBMITTED: $\quad$ November 2009

COMMITTEE CHAIR: Brent G. Hallock, Earth and Soil Science Professor

COMMITTEE MEMBER: Thomas J. Rice, Earth and Soil Science Professor COMMITTEE MEMBER: W. Keith Patterson, Crop Science Professor 


\begin{abstract}
Implementation of Sustainable Management Practices at Two California Central Coast Vineyards and Their Effects on Soil Fertility
\end{abstract}

Dawn Michelle Stimson

"Sustainable agriculture" has gained increased popularity in recent years. This study was conducted to determine the effects of sustainable management practices on soil fertility at two California Central Coast vineyards. The effects of cover crops (Erosion Control Mix - blando brome [Bromus hordeaceus], hykon rose clover [Trifolium hirtum All.], and zorro annual fescue [Vulpia mourns]), green waste compost (Forest Blend), and reduced tillage on soil fertility were investigated in San Luis Obispo, California on a clay and sandy loam soil. Between the fall 2007 and spring 2008, which had a low precipitation amount (13.3 \& 15.6 inches), there was a significant difference ( $P$ $<0.001$ to 0.007$)$ between vineyards in terms of their mean soil nutrient and ratio concentrations. The range of soil values (soil $\mathrm{pH}, \mathrm{P}, \mathrm{K}$, exchangeable $\mathrm{Ca}, \mathrm{Mg}$, and $\mathrm{K}$, $\mathrm{OM}, \mathrm{Ca} / \mathrm{Mg}$ and $\mathrm{C} / \mathrm{N}$ ratios) was either completely separate or different between Vineyard One and Two. There was almost no significant difference found between treatments and their effects on soil nutrients, exchangeable cations, and ratios. However, there were some noticeable effects on soil nutrients, exchangeable cations and ratios. Soil $\mathrm{P}$ and $\mathrm{K}$ concentrations increased in most areas (except cover crop/till where it decreased slightly). Soil P increases ranged from 14 to $143 \%$ while potassium increases ranged from 9 to $78 \%$. Soil OM increased in all areas at both vineyards (5 to $55 \%) . \mathrm{Ca} / \mathrm{Mg}$ ratios increased in some areas between 8 and $43 \% . \mathrm{C} / \mathrm{N}$ ratios increased in all areas between 5 and $85 \%$. Soil type appears to affect soil nutrients, exchangeable cations, and ratios more than sustainable management practices.

Keywords: Sustainable, vineyard, and soil nutrients. 


\section{ACKNOWLEDGEMENTS}

First and foremost, I would like to thank God for the wonderful opportunity and blessing of returning to Cal Poly to obtain my Master's. Second, I would like to thank my family, especially my mom, for supporting and encouraging me throughout my course work and research to hang in there. For without her, I may not have finished (in a timely manner). Next, I would like to thank the grower's, Jean-Pierre Wolff and John Salisbury, for allowing me to conduct my research on part of their land. In addition, I would like to thank my wonderful advisor, Brent Hallock, for all the guidance and support during my project and Tom Rice and Keith Patterson for their expertise and wisdom into the vineyard world. I would also like to thank the Fruit Grower's Lab in Santa Paula for donating the analysis of most of my soil samples. Without their generous donation, my project would not be the same. I would like to thank Craig Stubler of Cal Poly for generously running a majority of my carbon and nitrogen samples, and for helping me with field sampling supplies numerous times, sometimes at the last minute. Lastly, I would like to thank Danielle Castle for helping me collect numerous soil samples (half in clay) at various times during the year, implementing treatments in the cold and on hill slopes, and for everything else. She was truly a blessing, for which I am grateful. 


\section{TABLE OF CONTENTS}

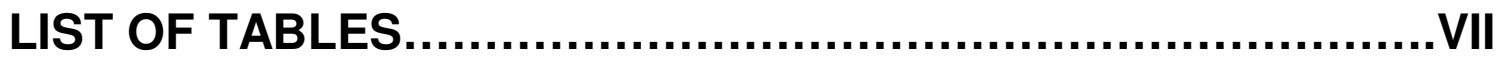

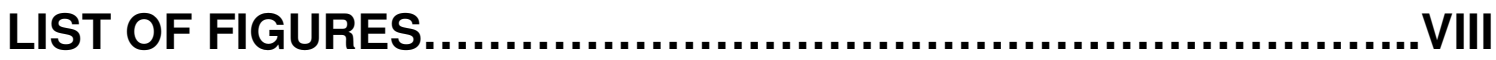

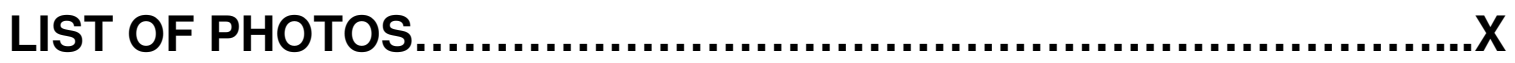

CHAPTER

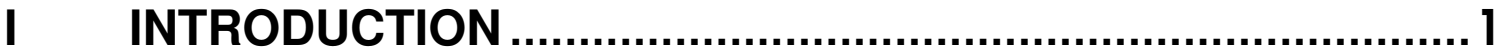

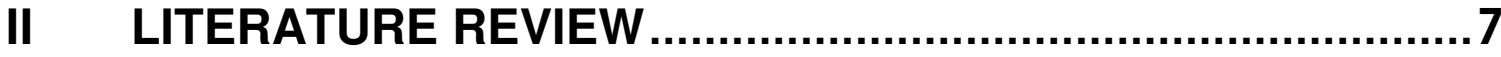

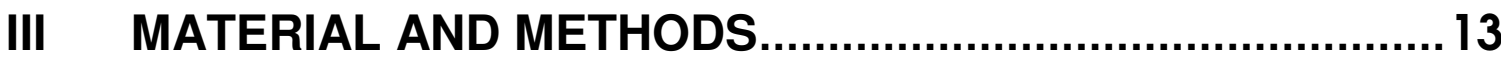

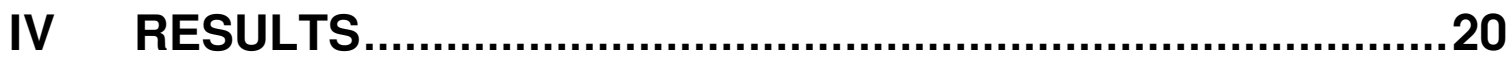

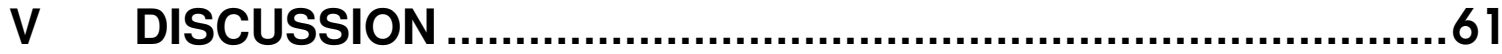

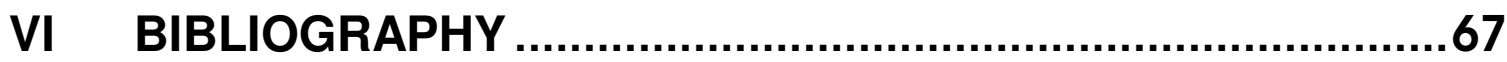

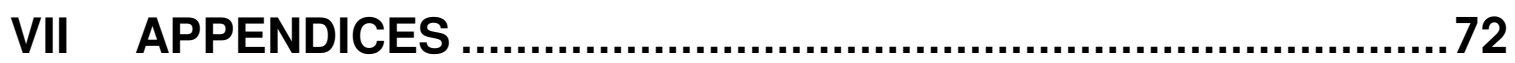

A VINEYARD ONE SOIL PROFILE DESCRIPTION........................72

B COMPOST LAB ANALYSIS................................................. 73

C ORIGINAL SOIL LAB DATA ................................................. 


\section{LIST OF TABLES}

Table

$1 \quad \mathrm{P}$ Values for Select Nutrients and Cations.

2 Vineyard One Select Nutrient and Exchangeable Cations.

3 Vineyard Two Select Nutrient and Exchangeable Cations.

4 Vineyard One Organic Carbon, Nitrogen and Matter.

5 Vineyard Two Organic Carbon, Nitrogen and Matter.

6 Vineyard One Select Soil Nutrient Ratios

7 Vineyard Two Select Soil Nutrient Ratios

8 Vineyard One Soil Nutrient Content Post Treatment in Percentages.

9 Vineyard Two Soil Nutrient Content Post Treatment in Percentages.

Page 21 22 23 44 44 54 54 62 62 


\section{LIST OF FIGURES}

Figure Page

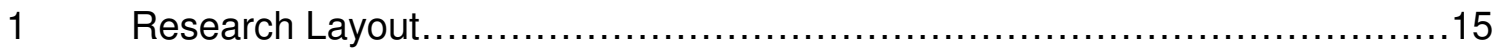

2 Matrix Plot for Soil pH, Phosphorus, Potassium, Organic Matter, Ca/Mg Ratio, $\mathrm{C} / \mathrm{N}$ Ratio................................................................21

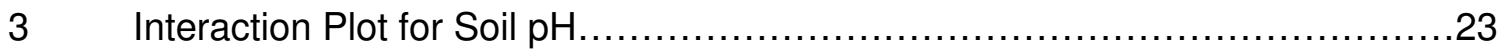

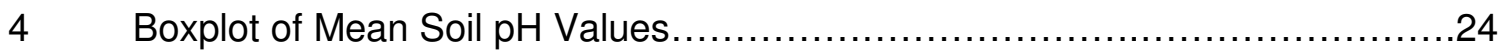

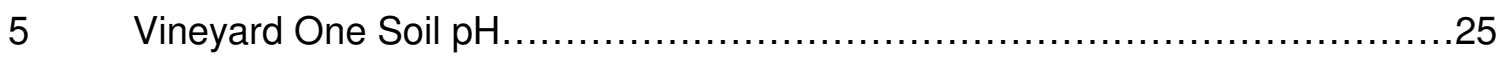

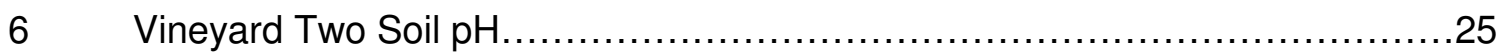

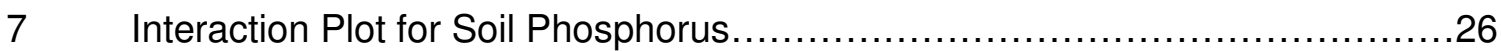

$8 \quad$ Vineyard One Soil Phosphorus Concentrations ................................27

$9 \quad$ Vineyard Two Soil Phosphorus Concentrations.................................

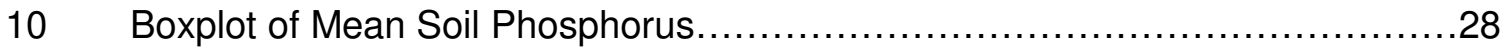

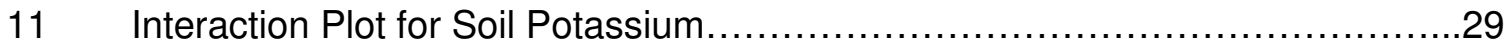

12 Vineyard One Soil Potassium ...............................................

13 Vineyard Two Soil Potassium .............................................

14 Boxplot of Mean Soil Potassium..........................................

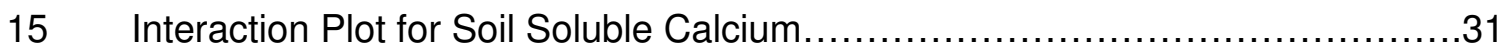

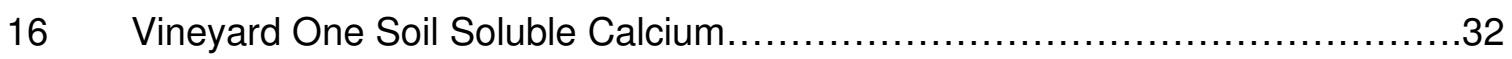

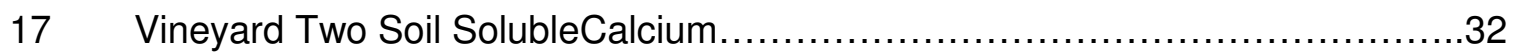

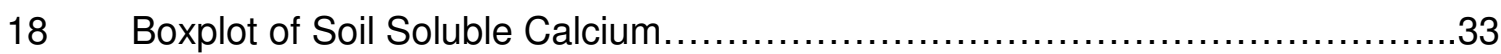

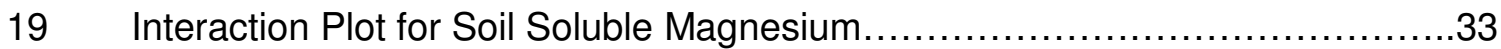

20 Vineyard One Soil Soluble Magnesium ........................................

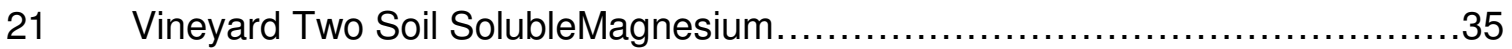

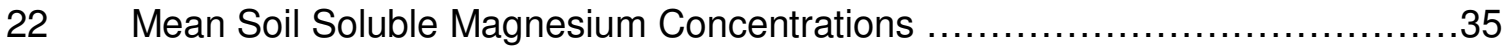

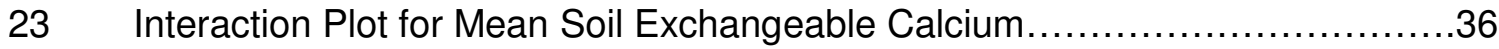

24 Vineyard One Mean Soil Exchangeable Calcium ............................. 37

25 Vineyard Two Mean Soil Exchangeable Calcium..............................

26 Boxplot of Mean Soil Exchangeable Calcium .................................

27 Interaction Plot for Mean Soil Exchangeable Magnesium..........................38

28 Vineyard One Mean Soil Exchangeable Magnesium............................39

29 Vineyard Two Mean Soil Exchangeable Magnesium...........................40

30 Boxplot of Mean Soil Exchangeable Magnesium...............................40

31 Interaction Plot for Mean Soil Exchangeable Potassium .......................41 
32 Vineyard One Mean Soil Exchangeable Potassium.........................42

33 Vineyard Two Mean Soil Exchangeable Potassium...........................42

34 Boxplot of Mean Soil Exchangeable Potassium..............................43

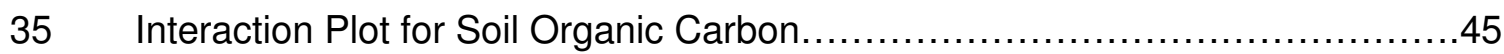

36 Vineyard One Soil Organic Carbon................................................ 46

37 Vineyard Two Soil Organic Carbon...........................................46

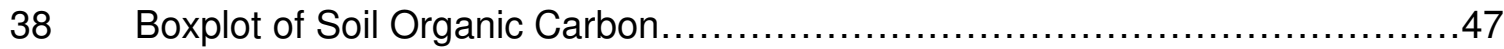

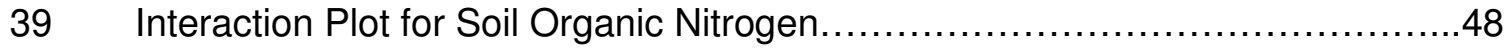

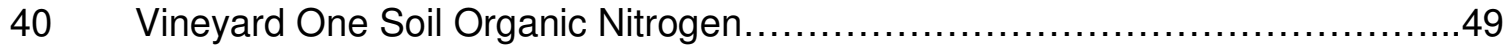

$41 \quad$ Vineyard Two Soil Organic Nitrogen.......................................... 49

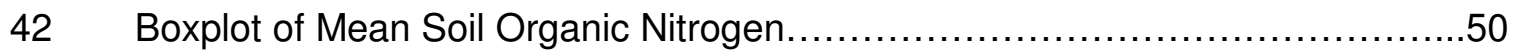

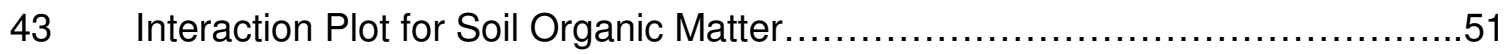

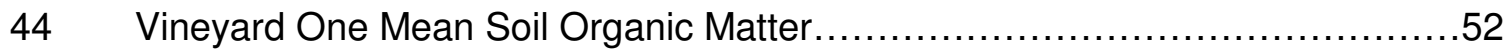

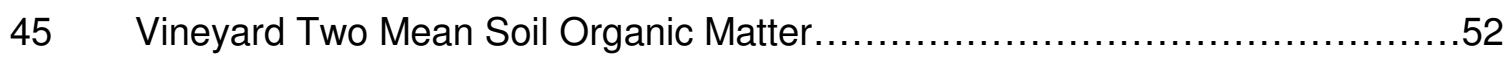

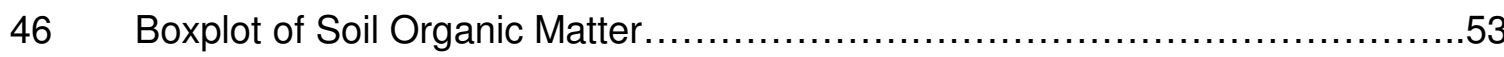

47 Interaction Plot for Mean Soil Exchangeable Ca/Mg Ratios......................55

48 Vineyard One Mean Soil Exchangeable Ca/Mg Ratios...........................56

49 Vineyard Two Mean Soil Exchangeable Ca/Mg Ratios..........................56

50 Scatterplot of Soil pH vs. Exchangeable Ca/Mg Ratios.........................57

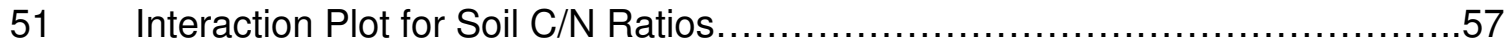

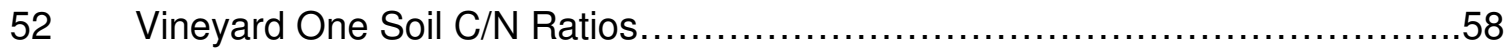

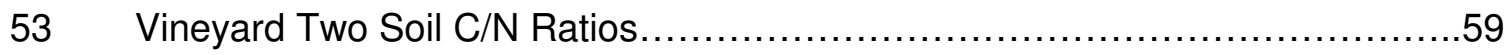

54 Boxplot of Mean Soil C/N Ratios........................................... 59

55 Interaction Plot for Vineyard One Soil C/N Ratios............................60

56 Interaction Plot for Vineyard Two Soil C/N Ratios...........................60 


\section{LIST OF PHOTOS}

Photo Page

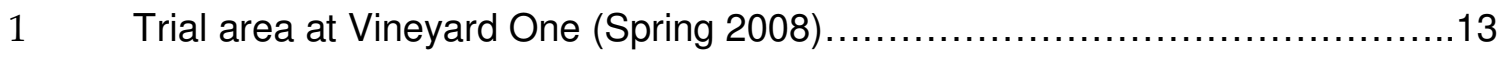

2 Grad assistant, Danielle Castle, manually broadcasting cover crop seed at Vineyard One (December 2007) ..........................................

3 Field staff applying compost at Vineyard Two (December 2007) ...............17

$4 \quad$ Tilled row at Vineyard One (May 2008) ...................................... 17

$5 \quad$ No-till row at Vineyard One (May 2008) ...................................

$6 \quad$ Author collecting soil samples at Vineyard Two (December 2007)................17

7 Danielle Castle, grad assistant, collecting soil samples at Vineyard

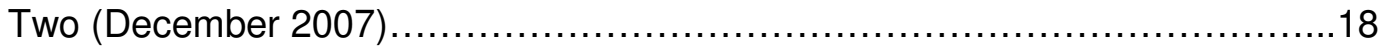

$8 \quad$ Author grinding soil samples for lab analysis (Summer 2008).................18

9 Author digging pit at Vineyard One (November 2008) .......................18

10 Kris Osterloh, pit assistant, at Vineyard One (November 2008)..............19 


\section{INTRODUCTION}

Land degradation, hence soil degradation, is common around the world as a result of increased agriculture production, industrial activities, and human occupation. Agriculture systems have been shown to increase environmental harm (Tilman, 1999). The world's natural resources are dwindling at a rapid rate. Agricultural processes can overuse and deplete natural resources (Pretty, 2008). In addition, the use of synthetic fertilizers can cause detrimental effects to soils and plants including the death of beneficial microorganisms, root burn from over application, and increased toxic salt concentrations. With all this in mind, growers are seeking practices that reduce environmental harm, while maintaining production. "Sustainable agriculture" has gained increased popularity in recent years.

Sustainable agriculture practices protect and conserve natural resources and help farm managers produce quality crops (Gomez et al., 1996). The legal definition of sustainable agriculture is "an integrated system of plant and animal production practices having a site-specific application that will over the long-term: 1) satisfy human food and fiber needs, 2) enhance environmental quality and the natural resource base upon which the agriculture economy depends, 3) make the most efficient use of nonrenewable resources and on-farm resources and integrate, where appropriate, natural biological cycles and controls, 4) sustain the economic viability of farm operations; and 5) enhance the quality of life for farmers and society as a whole" (U.S. Code Title 7, Section 3103) (USDA, 2009). The goals of sustainable agriculture include: social equity, economic equity, and economic profitability.

Sustainable vineyard practices can include the incorporation of natural admendments/fertilizers. Natural fertilizers provide many benefits to the soil compared 
to those from synthetic fertilizers. Both add nutrients required by plants. However, the soil and plants need more than nutrients. They need living organisms and organic matter $(\mathrm{OM})$ to be productive. Synthetic fertilizers do not provide these. Natural admendments add beneficial microorganisms to the soil that can control harmful pathogens, add OM, nutrients, and provide a habitat for beneficial anthropods.

Sustainable management practices can include natural admendments through the incorporation of cover crops, compost, and reduced tillage. Cover crops are defined as any plant species used singly or in a mixture, which is deliberately sown between vine rows (Coombe and Dry, 1992). Cover crops provide many benefits to the soil including: OM addition; increased infiltration rate, nitrogen addition (legumes), erosion control, reduce dust, attraction of beneficial anthropods, and improved soil structure (Ingels and Klonsky, 1998). Common cover crops can include barley (Hordeum vulgare), tall fescue (Festuca arundinacea), and California brome (Bromus carinatus) (Stimson, 2005). Compost is rich in nutrients, produced from decayed plant and animal waste and can be used in farms and vineyards to improve soil by adding OM (including organic carbon [C] and nitrogen $[\mathrm{N}])$, reducing weeds, improving soil structure, providing nutrients to the soil and by increasing microbial activity and root penetration. Microbial activity plays a major role in soil by breaking down $\mathrm{OM}$ and converting required plant nutrients to available forms. Green waste compost is rich in OM, holds in moisture and is usually free of contamination (Pickering et al., 1998). Organic matter is comprised of various plant and animal residues. Its major constituents include a couple major building blocks of life: carbon and nitrogen. It plays a major role in soil because of its many beneficial factors including: providing a nutrient reservoir for plant $\mathrm{N}, \mathrm{P}$, and sulfur, providing a food for microorganisms, improving aeration and water infiltration, increasing water-holding capacity, providing large amounts of cation exchange capacity (CEC), and strengthening soil aggregates, thus improving soil structure. Reduced tillage is less harmful to soil 
structure and has been shown to improve soil health (Steenwerth and Belina, 2008). In addition, lower tillage can increase the activities of beneficial fungi and earthworms in soil (Frances et al., 2006). Conventional tillage can cause negative affects to the soil including: reduced soil moisture, replanting of weed seeds, and the breakdown of soil aggregates.

Sustainable vineyard practices have gained in popularity since the 1980 s, to counter the soil degradation, reduced produce quality and environmental pollution that began in the 1950s (Stamatiadis et al., 1996, Pretty, 2008, and Ingels, 1992). Many vineyard growers today incorporate sustainable management practices. Up to one third of California's growers, utilize sustainable farming (Yield Wine Bar, 2008).

Soil health and quality play a major role in sustainable farm management. Some view this as the "cornerstone" of sustainability (Scholfield, 2008). It affects natural resources, plant, animal life and human health, and crop productivity. Soil health can be defined as "The capacity of a soil to function, within ecosystem and land-use boundaries, to sustain biological productivity, maintain environmental quality and promote plant and animal health" (Doran and Parkin, 1996). Assessing soil quality is vital for productive farms and vineyards and a healthy environment.

Previous studies of soil health have focused on organic practices (Mäder 2008 and Hepperly 2008, etc.) and conventional practices. Many of these studies have been conducted on farms and vineyards in the Midwest and overseas. Local studies would help growers and researchers determine which sustainable practices are critical to plant productivity and environmental quality. In addition, finding alternative ways to provide plant nutrients, such as $\mathrm{N}$ and $\mathrm{P}$, would reduce growers consumption of synthetic fertilizers (Doran and Jones, 1996).

Soil fertility can be defined as a soil's ability to supply mineral nutrients (Grant, 2002). It plays a critical role in vineyard health and productivity. Several nutrients and 
ratios that are of concern to wine grape growers and were evaluated in this project include: $\mathrm{P}$, potassium $(\mathrm{K})$, exchangeable calcium $(\mathrm{Ca})$, magnesium $(\mathrm{Mg})$ and potassium (K), OM, organic $\mathrm{C}$, organic $\mathrm{N}, \mathrm{Ca} / \mathrm{Mg}$ ratios, and $\mathrm{C} / \mathrm{N}$ ratios. Phosphorus is present in all living cells and is utilized by plants to form nucleic acids (Deoxyribonucleic acid [DNA] \& Ribonucleic acid [RNA]). It is also used in storage \& transfer of energy thru Adenosine Tri-Phosphate (ATP) \& adenosine diphosphate, (ADP). In vineyards, P makes up approximately $1-3 \%$ of dry weight vines. Optimum concentrations of $P$ in vineyard soils range from 35 to 80 parts per million $(\mathrm{ppm})^{1}$. Potassium is essential for translocation of sugars and starch formation in plants. It is also important for efficient water use. Potassium makes up to $3 \%$ of dry weight of vines. Deficiency of $\mathrm{K}$ can affect ripeness, cause leaf drop, yield loss and reduce vine growth. Optimum concentrations of $\mathrm{K}$ in vineyard soils range from 100 to $250 \mathrm{ppm}$. In plants, calcium plays an essential part of cell wall structure and is required for the formation of new cells. Calcium can be found in soil solution (most readily available form of calcium to plants) or on the cation exchange sites. It typically accounts for $70-85 \%$ of the CEC. Cation exchange is one mechanism by which plants uptake this nutrient. Desirable concentrations of exchangeable $\mathrm{Ca}$ in soil range between 60 and $80 \%$ of the total CEC. Magnesium is essential in plants for photosynthesis and activation of enzymes required for growth. Magnesium can be found in solution (most readily available form of magnesium for plants) or on the exchange sites. Desirable levels of exchangeable $\mathrm{Mg}$ in vineyard soils range between 15 and $30 \%$ of the total CEC. Ca/Mg ratios in the soil vary. In vineyard soils, optimum $\mathrm{Ca} / \mathrm{Mg}$ ratios range between 2:1 and 10:1. Optimum concentrations of exchangeable $\mathrm{K}$ in vineyard soils range between 5 and $10 \%$ of the total CEC. OM concentrations in vineyard soils vary depending on soil type and management practices.

\footnotetext{
${ }^{1}$ Optimum vineyard nutrient concentrations ( $\mathrm{P}, \mathrm{K}$, exchangeable $\mathrm{Ca}, \mathrm{Mg}$ and $\mathrm{K}$ ) and ratios $(\mathrm{Ca} / \mathrm{Mg})$ provided by Steve Vierra, Vineyard Professional Services, Inc.
} 
However, increased levels of $\mathrm{OM}$ are desired by many growers. Carbon is one of the basic building blocks for plant life (California Fertilizer Association, 1995). Organic C in the soil is found in roots, microbes, plant material, fresh and decaying $\mathrm{OM}$, and recalcitrant humus. Organic $\mathrm{C}$ is important for its role in microbial respiration. Organic $\mathrm{N}$ can be found in the same pools as organic $\mathrm{C}$, but in a much smaller amount. Organic $\mathrm{N}$ provides an energy source for microbes to conduct respiration. It's unavailable to plants until it is converted to ammonia and ammonium through mineralization. Nitrogen, in the form of ammonium (the nitrate form is preferred), can be used by the plants to synthesize amino acids and is required for chlorophyll, nucleic acids, and enzymes. C/N ratios in soil can vary. Optimum $\mathrm{C} / \mathrm{N}$ ratios are around 10:1.

To evaluate the effects of sustainable management practices on soil fertility (select chemical properties) in vineyards, a field study was established in two vineyards on the California Central Coast (San Luis Obispo County). Three management practices were chosen because of their beneficial effects: cover crop, compost, and reduced tillage/disking.

The cover crop used in this project was S \& S Seeds Erosion Control Mix (blando brome [Bromus hordeaceus], hykon rose clover [Trifolium hirtum All.], and zorro annual fescue [Vulpia myuros]). This mix was selected because of its quick growing properties and legume inclusion. Blando brome is a grass known to be low growing, quick maturing, full of dense/fibrous roots, and reseeds well. Hykon rose clover is a legume described as: earliest maturing; grows well in dry and acidic soils; and reseeds well. Zorro annual fescue is known to be fast growing, early maturing, reseeds effectively, and is cheap.

Green waste compost (Forest Blend Compost) from the local landfill was used in this project. The compost was comprised of yard materials, excluding woody, palm and soil material. It was selected because of its popularity among local growers. In addition, 
the participating growers were hesitant to try farmyard manure for fear it would affect wine quality.

Reduced tillage/disking (i.e., to a depth of 6 inches) was incorporated to encourage growers to shift to reduced or no-till practices. This was done using a rotatiller and disc.

The study's objective is to identify effects of sustainable management practices (i.e., cover crop, compost, and reduced till) on soil fertility (select chemical properties). It was hypothesized that these practices would benefit soil fertility by increasing soil nutrients. The purpose was to show that sustainable management practices improve the chemical properties of the soil and to provide research in the field of sustainability on the Central Coast in the hope that sustainable agriculture will become a common practice, not an alternative one. 


\section{LITERATURE REVIEW}

Effects of two cover crops (Secale cereale L. cv. Merced [rye] and Triticosecale Wittm. Ex A. Camus cv. Trios 102 [trios]) on soil fertility in row middles were evaluated over a three year period at a vineyard on the Central Coast of California (Smith, et al., 2008). Organic matter increased in the two cover crop areas (Trios - $0.35 \%$ increase in OM, Rye $-0.23 \%$ OM) over the course of the project vs. the control/bare (2002: 1.02005 Bare: $1.10 \% \mathrm{OM})$. However, nutrient concentrations ( $\mathrm{N}, \mathrm{P}$, and $\mathrm{K}$ ) varied only slightly between the cover crops and the control/bare area during the trial. Phosphorous concentrations ranged from $21.6 \mathrm{ppm}$ (Rye) to $24.3 \mathrm{ppm}$ (Bare). Potassium concentrations ranged from $352.8 \mathrm{ppm}$ (Trios) to $365.5 \mathrm{ppm}$ (Rye).

Morlat and Jacquet (2003) studied the effects of permanent cover on soil chemical properties over a 17-year period in a vineyard located in the Loire Valley, France. Three treatments were applied and compared: 1) Permanent grass (Festuca arundinacea cv. Manade) over $50 \%$ of the area; 2) permanent grass over $25 \%$ of the area; and 3 ) herbicide. Soil samples collected from the covered areas had significantly higher concentrations of OM (13.2 and 14.3 grams per kilogram $[\mathrm{g} / \mathrm{kg}]$ ) than from the herbicide treated area $(9.6 \mathrm{~g} / \mathrm{kg})$. Soil $\mathrm{C} / \mathrm{N}$ ratios were slightly higher in the cover areas $(9.3$ and 10.0) than in the herbicide area (9.0). Exchangeable $\mathrm{K}$ was 0.30 and $0.36 \mathrm{~g} / \mathrm{kg}$ in the cover areas and $0.22 \mathrm{~g} / \mathrm{kg}$ in the herbicide area. Available $\mathrm{P}$ was similar in all areas $(0.31$ to $0.36 \mathrm{~g} / \mathrm{kg})$.

Effects of two perennial cover crops (strawberry clover [Trifolium fragiferum L 'Palestine'] and a perennial native bunch grass mix [Elymus glaucus Buckley "meadow barley", Hordeum branchyantherum Nevski "meadow barley", and Bromus carinatus Hook. \& Arn. "California Brome") on soil nitrogen was studied over a two year period at a vineyard located in Sacramento, California (King and Berry, 2005). Total soil N 
concentrations increased only slightly during the course of the project. In July 2001 there were, on average, $0.21 \% \mathrm{~N}$ in the bunchgrass mix area and $0.25 \% \mathrm{~N}$ in the clover area. In May 2002, there were $0.22 \% \mathrm{~N}$ in the bunchgrass mix area and $0.26 \% \mathrm{~N}$ in the clover area.

The Rodale Institute, in collaboration with the United States Department of Agriculture (USDA) Agriculture Research Service, conducted a field trial to analyize the effects of organic and conventional practices on maize, soybean and the soil (Hepperly, et al., 2008) between 1981 and 2005. Three practices were evaluated: 1) conventional practices (use of commercial fertilizers and chisel plow), 2) manure based organic (cattle manure and moldboard plow; and 3) legume based organic (hairy vetch [Vicia villosa] and red clover [Trifolium pratense] as a cover crop/green manure and moldboard plow). Both organic systems had higher organic $C$ concentrations (legume $-2.4 \% O M$, manure $-2.5 \% \mathrm{OM})$ than the conventional system $(2.0 \% \mathrm{OM})$ at the end of the trial.

A four-year study to compare four farming systems and their effects on tomatoes, safflower, winter legume, beans and soil was conducted at the Sustainable Agriculture Farming Systems at UC Davis between 1988 and 1992 (Clark et al., 1998). The four systems included: organic (chicken, sheep or dairy manure, and fish powder and kelp, along with vetch cover crop), low input (vetch cover crop and reduced amounts of fertilizer), conventional 2 and 4 year (fertilizers only). Phosphorus concentrations were higher in the organic and low input areas (19. $3 \mathrm{ppm}$ and $17.2 \mathrm{ppm}$ ) than those from the conventional areas (4 yr - 14.3 ppm and $2 \mathrm{yr}-15.1)$. Potassium concentrations were also higher (org - $323 \mathrm{ppm}$, low - 311) than from the conventional $(4 \mathrm{yr}-299 \mathrm{ppm}, 2 \mathrm{yr}$ -279 ppm). Soil OM was higher in the organic and low input areas (1.6\% and $1.62 \%)$ versus those found in the conventional areas $(4 \mathrm{yr}-1.48,2 \mathrm{yr}-1.39)$. Total $\mathrm{C}$ and $\mathrm{N}$ were also higher in the organic and low-input areas. Total $C$ ranged from 9.72 (2 yr) to 11.96 (organic). Total $\mathrm{N}$ ranged from 1.11 (2 yr) to 1.35 (organic). 
A two-year study was conducted to compare yard waste mulch and cover crops and their effects on soil in a lemon orchard by UC Cooperative Extension, Ventura-Santa Barbara County (Faber, 1999). Yard waste mulch was applied in the middles to a depth of 3 to 9 inches. Cover crops, including a Zorro fescue/bur medic mixture and barley, were used. Soils collected from the cover crop and mulch areas had higher concentrations of $\mathrm{P}$ and $\mathrm{K}$ in 4 out of 6 trial areas. Phosphorus concentrations followed a similar pattern with the highest concentrations found in two soils without fescue or mulch (40.6 ppm and $142 \mathrm{ppm}$ ). Potassium concentrations were higher in most of the areas with cover crop or mulch (182 ppm to $462 \mathrm{ppm}$ ), but the highest was found in a soil from a non-mulch area (564 ppm).

Conventional versus organic management practices on seven farms in the California Central Valley were evaluated (Andrews et al., 2002). Each farm incorporated conventional (not specified) and organic management practices (compost [gin trash], cover crop [wheat, Sudangrass, and barley], or manure amendments [chicken, turkey, dairy]). Soil OM was higher in all soils collected from the organic areas (5.7 to 12.4 soil quality indicator $\left.[\mathrm{SQI}]^{2}\right)$ than from the conventional ones (3.5 SQI to 11.6). In addition, concentrations of Olsen P (15 SQI to 55 SQI) were higher in all soils collected from the organic areas. CEC was higher in four out of six soils collected from the organic areas (13.3 SQI to 31.8 SQI) than those from the conventional areas (9.9 SQI to $29.3 \mathrm{SQI}$ ).

The effects of cover crops (Trios 102 and Merced rye) and tillage on soil were studied. A tandem disk and ring roller were used in the cultivation area. Total soil C was higher in the two cover crop areas $\left(9.45 \mathrm{mg} \mathrm{C} \mathrm{kg}^{-1}\right.$ and $\left.10.98 \mathrm{mg} \mathrm{C} \mathrm{Kg}^{-1}\right)$ than in the cultivation area $\left(7.18 \mathrm{mg} \mathrm{C} \mathrm{Kg}^{-1}\right)$.

\footnotetext{
${ }^{2}$ Soil quality indicator (SQI) is a comparative assessment technique that can be used to track changes on farms where management practices are implemented and evaluated for one to two seasons. SQI incorporates a minimum data set (MDS) of indicators that represent soil function, scores the MDS for soil performance, then incorporates the scores into an index of soil quality (Andrews et al., 2002).
} 
A four-year study was conducted to compare conservation tillage and cover crops (mix of Juan triticale, Merced ryegrain and common vetch) and their effects on soil properties with cotton and tomatoes in the San Joaquin Valley (Veenstra et al., 2006). Four treatments were applied: 1) conservation tillage with cover crop; 2) conservation tillage no cover crop; 3) standard tillage with cover crop; and 4) standard tillage no cover crop. Cover crops increased soil C in both tillage treatments by an average of 4,200 lbs per acre after four years. Concentrations of $\mathrm{P}$ were highest in the conservation till with no cover crop (17.1 ppm), but were similar to those in conservation till with cover crop (14.8 ppm). Potassium concentrations were higher in the areas with cover crops (cons. Till - 314 ppm, stand. Till -319 ppm) than from those without (cons till -303 ppm, stand till- 300).

Use of compost, cover crop and tillage and their effects on soil on a lettuce and broccoli farm were evaluated in the Salinas Valley (Jackson et al., 2003). Mixed compost consisted of municipal yard waste, salad mix, and manure. Cover crop included Merced rye (Secale cereale cv. Merced). Tillage was reduced to 8 inches. Total soil C was higher in the soils from the cover crop and compost areas (1.48 and $1.51 \%)$ than those without (1.37 and $1.41 \%$ ), as well as slightly higher in the area with conservation till and cover crop than standard till with cover crop. Total soil $\mathrm{N}$ had the same results as those of total soil C.

A four-year study was conducted at Indian Head, Saskatchewan to evaluate the effects of cultural practices on soil OM (among other constituents) (Campbell et al., 1991). Fertilization, green manure (sweet clover [Melilotus officinalis (L)], and cover cropping (bromegrass alfafa [Bromus inermis Leyss - Medicag sativa L.]) were applied in spring wheat (Triticum aestivum L.). Soil organic $\mathrm{C}$ was only slightly higher in the soils collected from the areas with green manure (39.5 and $\left.39.9 \mathrm{t} \mathrm{ha}^{-1}\right)$ and cover crop (41.5 and $42.2 \mathrm{t} \mathrm{ha}^{-1}$ ) than those that were fertilized only (39.6 and $\left.41.9 \mathrm{t} \mathrm{ha}^{-1}\right)$. 
Effects of three management practices on soil organic C were evaluated after a 19-year period in India (Majumder, et al., 2008). The three management practices included: 1) farmyard manure; 2) green manure (Sesbania sesban [L] Merr.); and 3) paddy straw. Soils collected from these areas had higher amounts of total organic C than those from the control or fertilized areas. Soils from the green manure had $86.4 \mathrm{Mg}$ ha $^{-1}$ total organic $\mathrm{C}$, whereas soils from the control had $70.8 \mathrm{Mg} \mathrm{ha}^{-1}$ total organic $\mathrm{C}$ and fertilizer had 83.3 $\mathrm{Mg} \mathrm{ha}^{-1}$ total organic $\mathrm{C}$.

Another study was conducted to evaluate the effects of Parthenium hysterophorus L. and its effects on soil properties as green manure (Biradar et al., 2006). Parthenium, Parthenium plus Glyricidia, and Parthenium plus farmyard manure were applied to rice. Soil samples collected from the Parthenium and Parthenium plus Glycidia had higher amounts of organic $\mathrm{C}$, and nutrients $(\mathrm{P}, \mathrm{K})$ than those collected from areas without organic manure additions. Soil organic C was $12.5 \%$ higher (0.63\%) with Parthenium plus Glycidia than without (0.56\%). Phosphorus, and potassium were $40.8 \%$ and $44.1 \%$ higher with Parthenium plus Glycidia $\left(40.4,325.7 \mathrm{~kg} \mathrm{ha}^{-1}\right)$ than without $(28.7,226 . \mathrm{kg}$ ha$\left.{ }^{1}\right)$.

Effects of different cultivation practices on soil quality were evaluated in four vineyards and one tomato farm with a Mediterranean climate in Greece (Vavoulidou et al., 2006). Each vineyard/farm used three different cultivation practices: 1) use of conventional agricultural practices (not specified), 2) organic practices including tillage and compost (commercial or manure), and 3) fallow (minimum 10 years). Soils had higher concentrations of $\mathrm{OM}$ at each farm in the organic treated area $(5 \mathrm{~g} \mathrm{~kg}-1$ to $16 \mathrm{~g}$ $\mathrm{kg}-1)$ than the conventional area $(4 \mathrm{~g} \mathrm{~kg}-1$ to $11 \mathrm{~g} \mathrm{~kg}-1)$. Soils collected from the fallow areas had higher exchangeable $\mathrm{K}$ concentrations in four out of five farms (2.4 [meg kg-1] to 5.2 meg kg-1) than from the other areas (1.0 meg kg-1 to 4.6 meg kg-1) and CEC in three out of five farms (54 meg kg-1 to 74 meg $\mathrm{kg}$-1) than from the other areas (36 meg 
$\mathrm{kg}-1$ to 70 meg $\mathrm{kg}-1$ ). No trends were observed for concentrations of $\mathrm{P}$ Olsen. Concentrations ranged from $5 \mathrm{mg} \mathrm{kg-1}$ (fallow area) to $200 \mathrm{mg} \mathrm{kg-1} \mathrm{(organic} \mathrm{area).}$

Effects of different cultivation practices on soil quality were evaluated in two vineyards with a Mediterranean climate in Greece over a one-year period (Stamatiadis et al., 1996). One vineyard incorporated organic practices: 1) application of poultry manure and 2) reduced tillage (depth of 10 to $15 \mathrm{~cm}$ ). The other vineyard incorporated conventional practices: 1) use of roundup and 2) no tillage. Phosphorus and available $\mathrm{K}$ concentrations were almost two times higher in soils collected from the organic area with reduced till $\left(58.8 \mathrm{Kg} \mathrm{ha}^{-1}\right.$ and $\left.1.20 \mathrm{~mol} \mathrm{Kg}^{-1}\right)$ than those from the conventional area with no till $\left(34.1 \mathrm{Kg} \mathrm{ha}^{-1}\right.$ and $\left.0.64 \mathrm{~mol} \mathrm{Kg}^{-1}\right)$. Organic $\mathrm{C}$ was higher in soil from the reduced till area (31.2 $\left.\mathrm{Mgha}^{-1}\right)$ than from the no till area (28.4 $\left.\mathrm{Mgha}^{-1}\right)$.

The effects of different farm management practices on soil quality were evaluated at a farm in North Dakota over an eleven-year period (Wienhold et al., 1998). Three tillage treatments were implemented: 1) conventional till (sweep plow, chisel plow, and double disk in the fall and spring), 2) minimum till (undercutter and one or two tillage's in the spring, plus herbicides), and 3) no till (herbicides). Areas with minimum and no till treatments had higher concentrations of organic $\mathrm{C}(17.90+1.71 \mathrm{Mg}$ ha-1 to $21.34+1.87 \mathrm{Mg}$ ha- 1$)$ and $\mathrm{N}$ concentrations $(1.27+0.12 \mathrm{Mg}$ ha- 1 to $1.54+0.13 \mathrm{Mg}$ ha1) than those with conventional till $(16.24+2.11 \mathrm{Mg}$ ha-1 and $16.45+1.71 \mathrm{Mg}$ ha-1) and $(1.12+0.15 \mathrm{Mg}$ ha- 1 and $1.12+0.11 \mathrm{Mg}$ ha- 1$)$. 


\section{MATERIAL AND METHODS}

\section{Site Descriptions}

The effects of different management practices on soil fertility were evaluated at two California Central Coast vineyards over a one-year period from fall, 2007 through summer, 2008. The vineyards are located on the California Central Coast, one in Edna Valley (Vineyard 1) (N $35^{\circ} 13.495, \mathrm{~W} \mathrm{120^{ \circ }}$ 35.449) and one in Avila Valley (Vineyard 2) (N $\left.35^{0} 11.747, \mathrm{~W} 120^{\circ} 42.5581\right)$.

Soils described in the field at Vineyard One were classified and mapped as Los Osos-Diablo complex, 9 to $15 \%$ slopes. This soil was classified in the field as a "fine, mixed, superactive, thermic Calcic Haploxeroll." These soils appear to be a Los Osos taxadjunct or a soil mapping inclusion. Soils in the area were classified and mapped as Diablo clay (fine, montmorillonic, thermic Chromic Pelloxererts) (USDA, 1984). The soil is formed in serpenititic alluvium parent material. Serpenititic parent material is ultramafic rock, which typically has an imbalance of calcium and magnesium - high magnesium, low calcium. Nitrogen, phosphorus, potassium and molybdenum levels may be low. Most serpentinitic soils are shallow, although some have been found to be deep. Serpentinite typically weathers to smectite clays that have a high shrink/swell potential. The runoff class is very high. Vegetation establishment in these areas can be difficult due to micronutrient deficiencies, low Ca:Mg ratios, and shallow rooting depths.

The slope in the project area is $12 \%$ located on a hillside, backslope position. The orientation is north to south with a south facing aspect. The surface soils are clays with a few clay loams. The climate is relatively mild. At the nearest national weather station approximately four miles from the vineyard, the 10-year mean annual 
precipitation was 21.21 inches $^{3}$ (Carpenter, J., 2009). Most rain is received between October and April. During the course of the study, between July 2007 and June 2008, the total rainfall was 14.56 inches. This was below the normal amount received. The project area is located in Block 1428 between rows 33 and 45. No grapes have been planted in the area. Teroldego vines (rare Italian varietal) are scheduled to be planted in the spring of 2010 , during a normal rain year.

Soils from a pit dug at Vineyard Two were mapped as Pismo-Tierra complex, 9 to 15\% slopes (AgQuest Consulting, 2000). Soils in the area were classified and mapped as Tierra soils (fine, montmorillonitic, thermic Mollic Palexeralf) (USDA, 1984). The soil weathers from sandstone parent material. The soils are comprised mostly of sandy loams with loamy sands. Most of these soils are shallow. They are excessively drained. The surface runoff class is medium to rapid. The hazard of soil blowing is high. In this case, because of the low $\mathrm{pH}$, the soils were limed prior to planting.

The slope in the project area is 7 to $20 \%$. The orientation is north to south with a southeast facing aspect. The surface soils are sandy loams with a few loamy sands. The climate is relatively mild. At the nearest national weather station, approximately 0.5 miles from the vineyard, the 10-year mean annual precipitation was 23.46 inches (Lindsey, J., 2009). Most rain is received between October and April. During the course of the study, between July 2007 and June 2008, the total rainfall was 13.33 inches $^{4}$. The project area is located in Block 31 between rows 12 and 24. Pinot noir grapes are planted there.

\footnotetext{
${ }^{3}$ Obtained from the National Climatic Data Center for the San Luis Obispo Airport site.

${ }^{4}$ Obtained from PG \& E weather reporter from the Diablo Canyon Ocean Lab.
} 


\section{Project Design and Implementation}

The field study was laid out in an identical strip-strip randomized block design. At each vineyard, twelve adjacent rows were selected within one block to receive different management practices. The two areas varied in size and were between 250 (Vineyard 1) to 400 feet long (Vineyard 2) with eight foot spacing between rows. Each block consisted of four sub-blocks (3 rows per sub-block) to account for possible soil differences in orientation. Each sub-block was divided into Area A (top half) and Area B (bottom half) to account for possible soil differences based on slope location.

The project used the following treatments: 1) cover crop, 2) green waste compost, and 3) reduced tillage, along with a control/bare. Treatments 1,2, and the control were replicated four times at each vineyard (Figure 1). Treatment 3 was replicated six times at each vineyard.

Figure 1. Research Layout

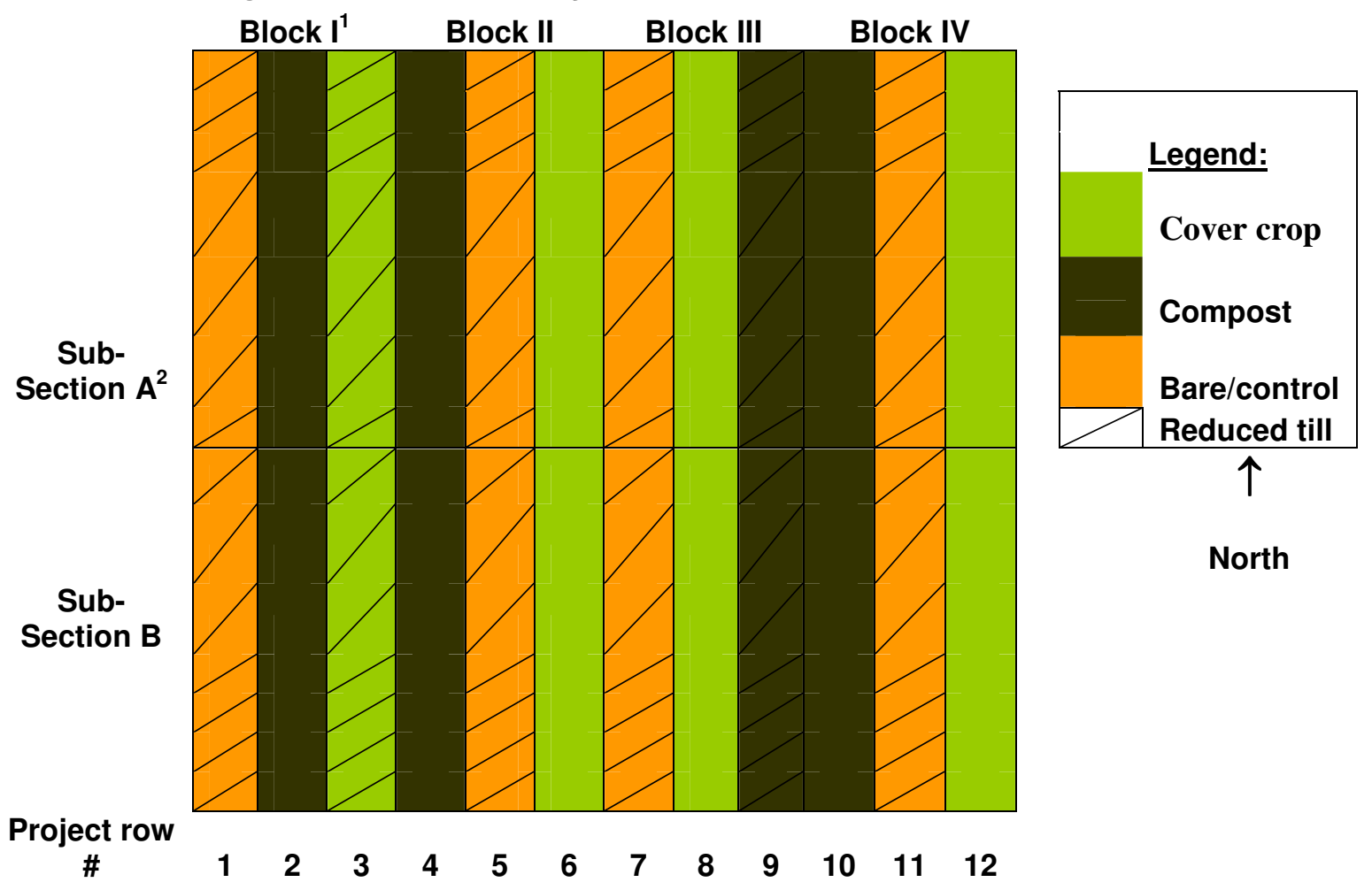




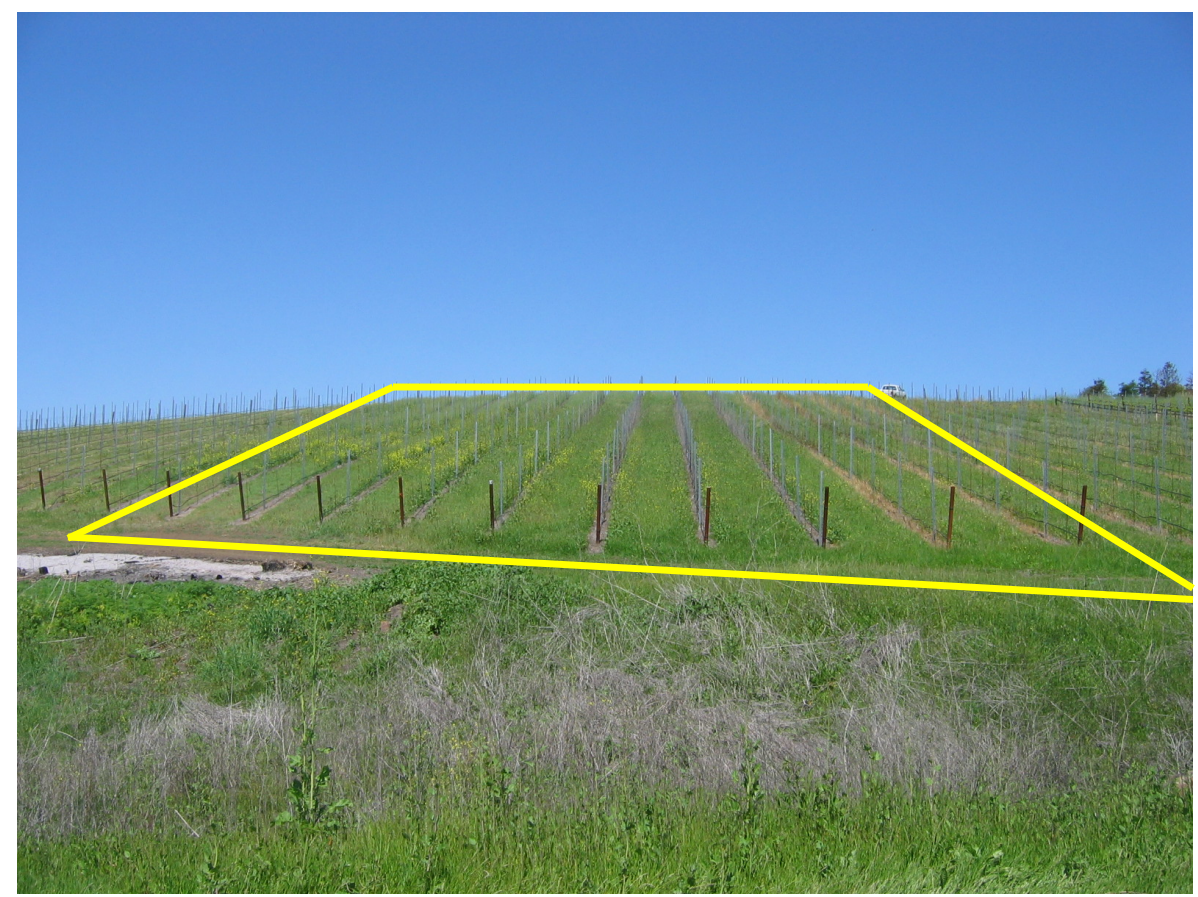

Photo 1: Trial area at Vineyard One (Spring 2008)

For cover cropping, four rows were randomly selected within each sub block. In December 2007, each row was manually raked to create $1 / 4$ inch grooves for the seeds. After raking, Erosion Control Mix seed (blando brome [Bromus hordeaceus], hykon rose clover [Trifolium hirtum All.], and zorro annual fescue [Vulpia mourns]) was hand broadcast at 40 pounds/acre. A lawn roller was used to cover the seed in each newly planted area.

For composting, four rows were randomly selected in each sub block. In December 2007, Forest Blend Compost, from the local landfill, was manually spread on the middle five feet of selected rows at a common grower's rate of 3 tons/acre.

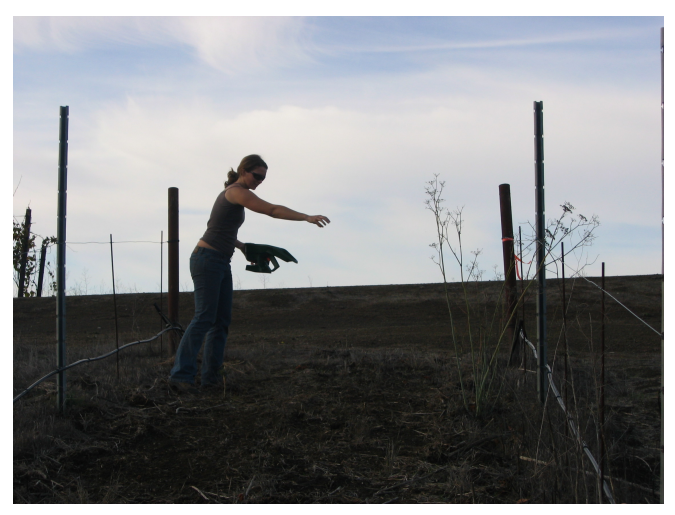

Photo 2: Grad assistant, Danielle Castle, manually broadcasting cover crop seed at Vineyard One (December 2007) 
Chemical make up can be found in

\section{Appendix A.}

In the spring of 2008 , both blocks were mowed to control weeds. During May and June 2008, every other row within each block was disked to a depth of approximately 6 inches.

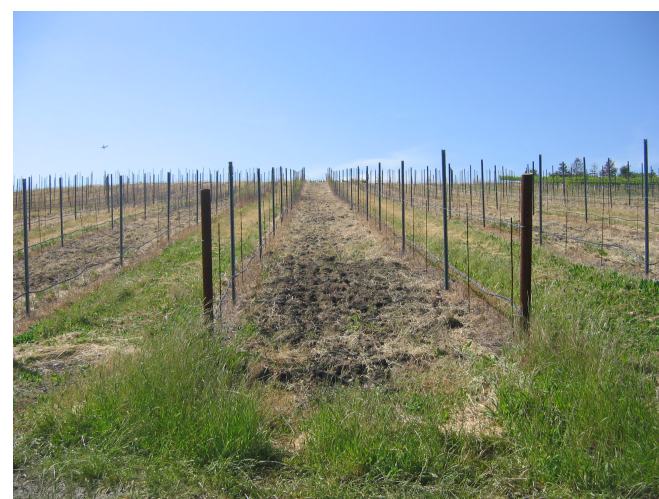

Photo 4: Tilled row at Vineyard One (May 2008)

Soil Sampling, Processing, and Analysis

In fall 2007, prior to cover cropping and composting, in spring 2008 following disking/mowing, and in late summer 2008, soil samples were collected. Hand augers from 0 to 12 inches $(0$ to $30.48 \mathrm{~cm})$ in depth were used at two locations in all rows (24 samples total, plus one duplicate, from each vineyard area). Sample locations were generated using a random feature

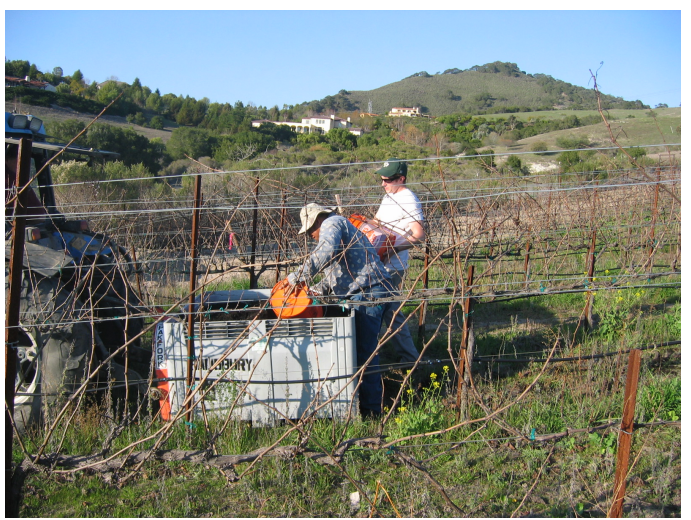

Photo 3: Field staff applying compost at Vineyard Two (December 2007)

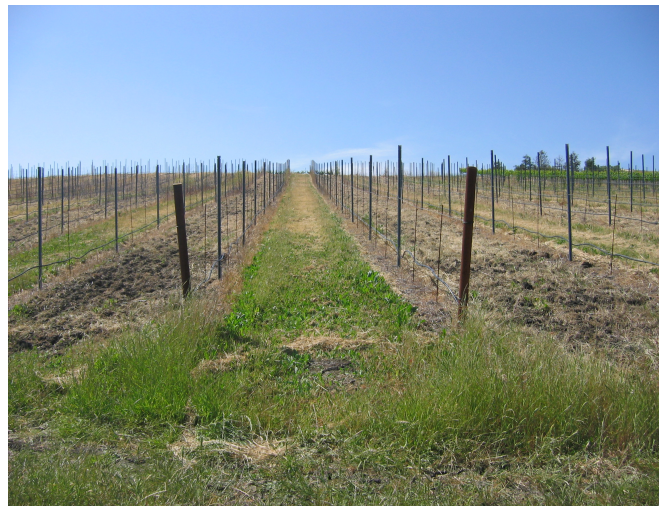

Photo 5: No-till row at Vineyard One (May 2008)

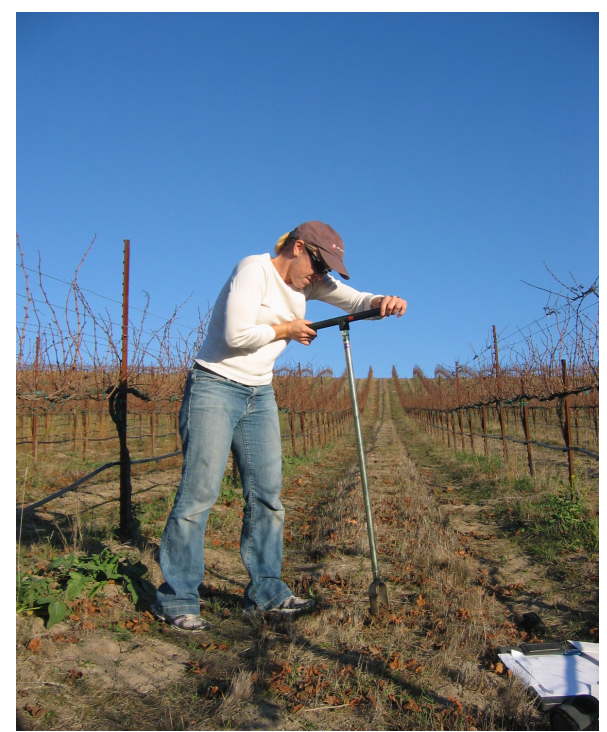

Photo 6. Author collecting soil samples at Vineyard Two (December 2007) 
in MS Excel. After collection, the samples were stored in bags provided by the laboratory until analysis could take place.

Well-mixed, air-dried samples were analyzed for physical and chemical properties at the Fruit Growers Laboratory in Santa Paula, California and at the California Polytechnic State University Earth and Soil Science Lab in San Luis Obispo, California ${ }^{5}$. Soil texture was determined using a hydrometer. Soil organic matter was determined by the loss on ignition method. Soil pH was determined using a $\mathrm{pH}$ probe/meter. Phosphorus (orthophosphate) was determined by either the Brae method $(\mathrm{pH}<7.2)$ or Olsen method ( $\mathrm{pH}>7.2)$. Potassium was determined by ammonium

acetate extraction. Soluble calcium and magnesium were extracted with deionized (DI) water and analyzed using the saturated paste method for

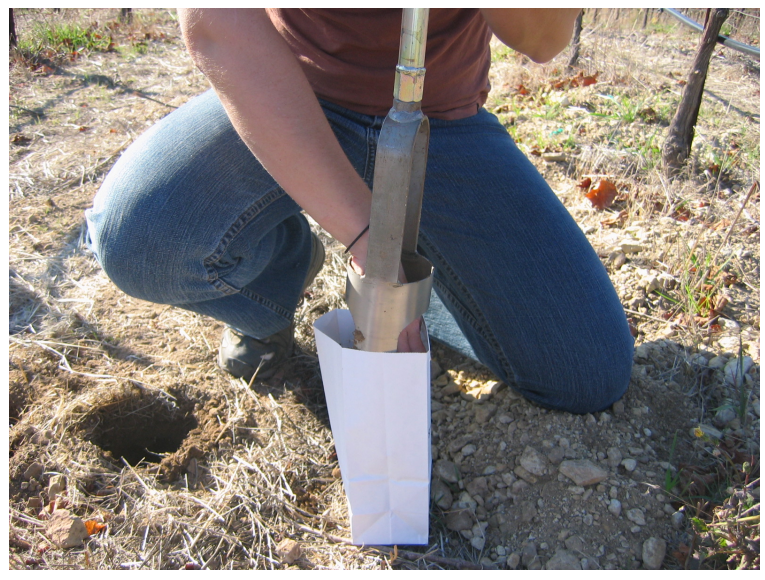

Photo 7. Danielle Castle, grad assistant, collecting soil samples at Vineyard Two (December 2007)

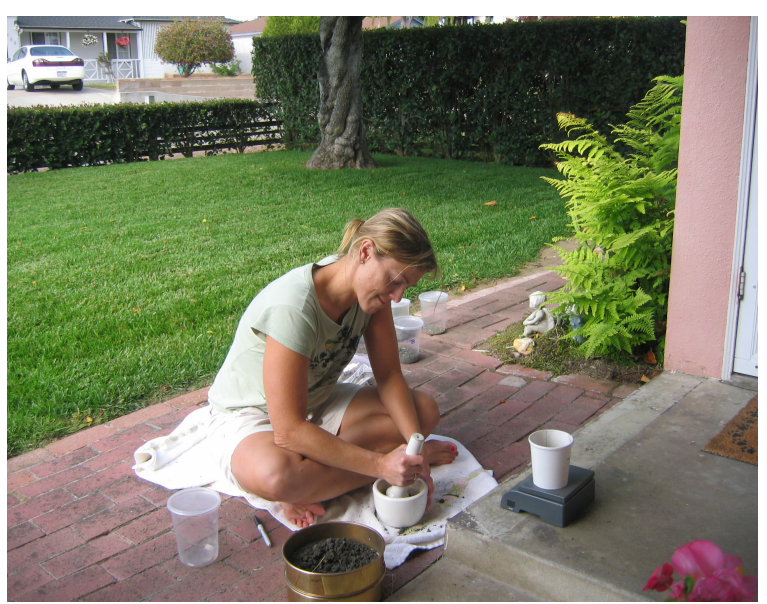

Photo 8. Author grinding soil samples (summer 2008)

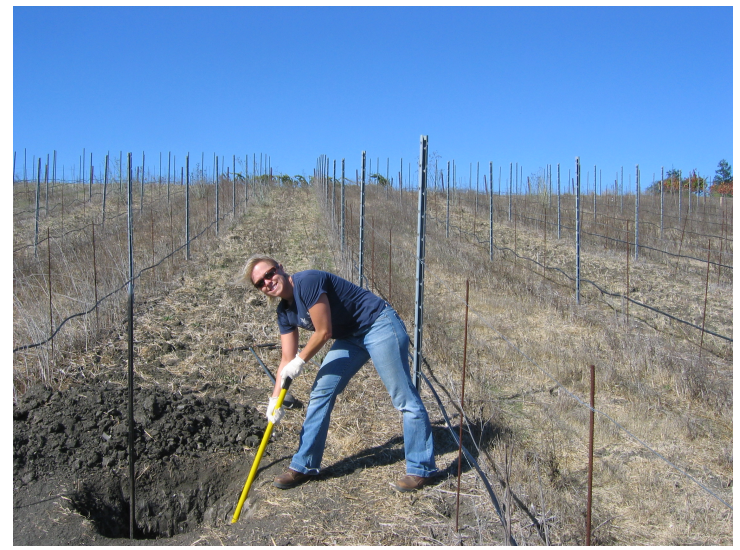

Photo 9. Author digging pit at Vineyard Two (November 2008)

${ }^{5}$ Organic $\mathrm{C}$ and $\mathrm{N}$ were analyzed at the Cal Poly Soils Lab. 
the soluble portion. Exchangeable calcium and magnesium were analyzed using the ammonium acetate extraction method for the exchangeable portion. Soil organic carbon $(\mathrm{C})$ and nitrogen $(\mathrm{N})$ were analyzed using carbon and nitrogen combustion analysis.

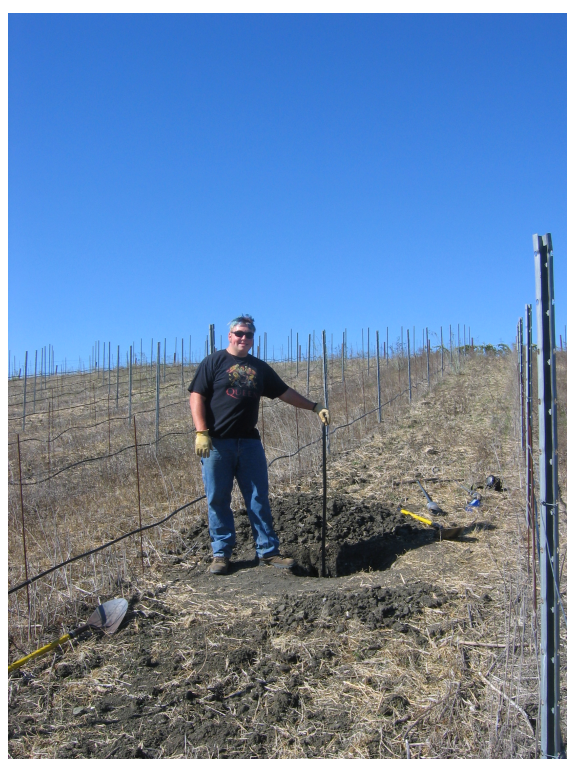

Photo 10. Kris Osterloh. (November 2008)

\section{Soils Information}

For Vineyard One, a soil pit was hand dug and described in the fall of 2008 (Appendix B).

For Vineyard Two, soil series information was obtained from a Suitability Study For Vineyard Development Bassi Property - Avila, California (AgQuest Consulting) ${ }^{6}$ as well as the San Luis Obispo Soil Survey (USDA, 1983).

\section{Statistical Analysis}

An analysis of covariance was used to analyze the research data in Minitab.

\footnotetext{
${ }^{6} \mathrm{~A}$ backhoe pit was dug and described in the middle of the trial area.
} 


\section{RESULTS}

\section{Statistics}

The following factors and their effects on soil response values $\mathrm{pH}$, phosphorus $[P]$, potassium $[\mathrm{K}]$, Cation Exchange Capacity (CEC) exchangeable $\mathrm{Ca}, \mathrm{Mg}$, and $\mathrm{K}$, organic matter $[\mathrm{OM}]$ percentage, organic carbon $(\mathrm{C})$ and nitrogen $(\mathrm{N}), \mathrm{CEC} \mathrm{Ca/Mg}$ ratio, and $\mathrm{C} / \mathrm{N}$ ratio) were analyzed: 1 ) treatment (compost, cover crop, or control/bare)/till (reduced till or no-till), 2) vineyard (soil type ${ }^{7}$ ), 3) block within vineyard (from left to right I, II, III, IV), 4) sub-block within block (A - upper half, B - lower half), and 5) sample time (pre or post treatment). The following interactions and their effects on soil response values were analyzed: 1) vineyard and sample time (pre or post treatment); 2) treatment/till and vineyard, and 3) treatment/till and sample time. In the ANOVA analysis, a significance value of 0.05 was used. In the model, both vineyards were run together to show common impacts of treatments and to determine if subtle trends exist.

\section{Overall/Soil}

There was a significant difference $(P<0.001$ to 0.007$)$ between vineyards in terms of their mean soil nutrient/ratio concentrations. This effected all nutrients, exchangeable cations and ratios except organic $\mathrm{C}, \mathrm{N}$ and matter. The range of soil values (soil $\mathrm{pH}, \mathrm{P}, \mathrm{K}$, exchangeable $\mathrm{Ca}, \mathrm{Mg}$, and $\mathrm{K}, \mathrm{OM}, \mathrm{Ca} / \mathrm{Mg}$ and $\mathrm{C} / \mathrm{N}$ ratios) was either completely separate or different between Vineyard One and Two. Their differences can be seen in Table 1 and Figure 2. At Vineyard One, the soils were primarily clay loams with clays. At Vineyard Two, the soils were sandy loams with loamy sands.

\footnotetext{
${ }^{7}$ Soil type was used as the main difference between vineyards as precipitation, climate, orientation, and practices were very similar during the course of the project.
} 


\begin{tabular}{|c|c|c|c|c|c|c|c|c|c|c|c|}
\hline Source & $\mathrm{pH}$ & $\begin{array}{c}P \\
\text { exch }\end{array}$ & $\begin{array}{c}\mathrm{K} \\
\text { exch }\end{array}$ & $\begin{array}{l}\text { CEC } \\
\text { Ca\% }\end{array}$ & $\begin{array}{c}\text { CEC } \\
\text { Mg\% }\end{array}$ & $\begin{array}{l}\text { CEC } \\
\text { K\% }\end{array}$ & OM & Org C & Org $N$ & $\begin{array}{c}\text { CEC } \\
\mathrm{Ca} / \mathrm{Mg} \\
\text { Ratio }\end{array}$ & $\begin{array}{r}\mathbf{C} / \mathbf{N} \\
\text { Ratio }\end{array}$ \\
\hline Treattill & NS & NS & 0.019 & NS & NS & NS & $<0.001$ & NS & 0.027 & NS & NS \\
\hline Vineyard & $<0.001$ & $<0.001$ & $<0.001$ & $\mid<0.001$ & $<0.001$ & $<0.001$ & NS & NS & NS & 0.007 & 0.001 \\
\hline Block(Vineyard) & 0.017 & NS & NS & NS & NS & NS & $<0.001$ & 0.024 & $<0.001$ & NS & NS \\
\hline Sub-block(Vineyard) & 0.004 & $<0.001$ & 0.045 & $<0.001$ & $<0.001$ & 0.039 & $<0.001$ & NS & 0.017 & NS & 0.041 \\
\hline Sample Time & NS & NS & NS & NS & NS & NS & NS & $<0.001$ & $<0.001$ & NS & $<0.001$ \\
\hline Vineyard*Sample Time & NS & NS & NS & NS & NS & NS & NS & NS & NS & NS & 0.001 \\
\hline Treattill ${ }^{\star}$ Vineyard & NS & NS & NS & NS & NS & NS & NS & NS & NS & NS & NS \\
\hline Treattill“Sample Time & NS & NS & NS & NS & NS & NS & NS & 0.009 & 0.016 & NS & NS \\
\hline
\end{tabular}

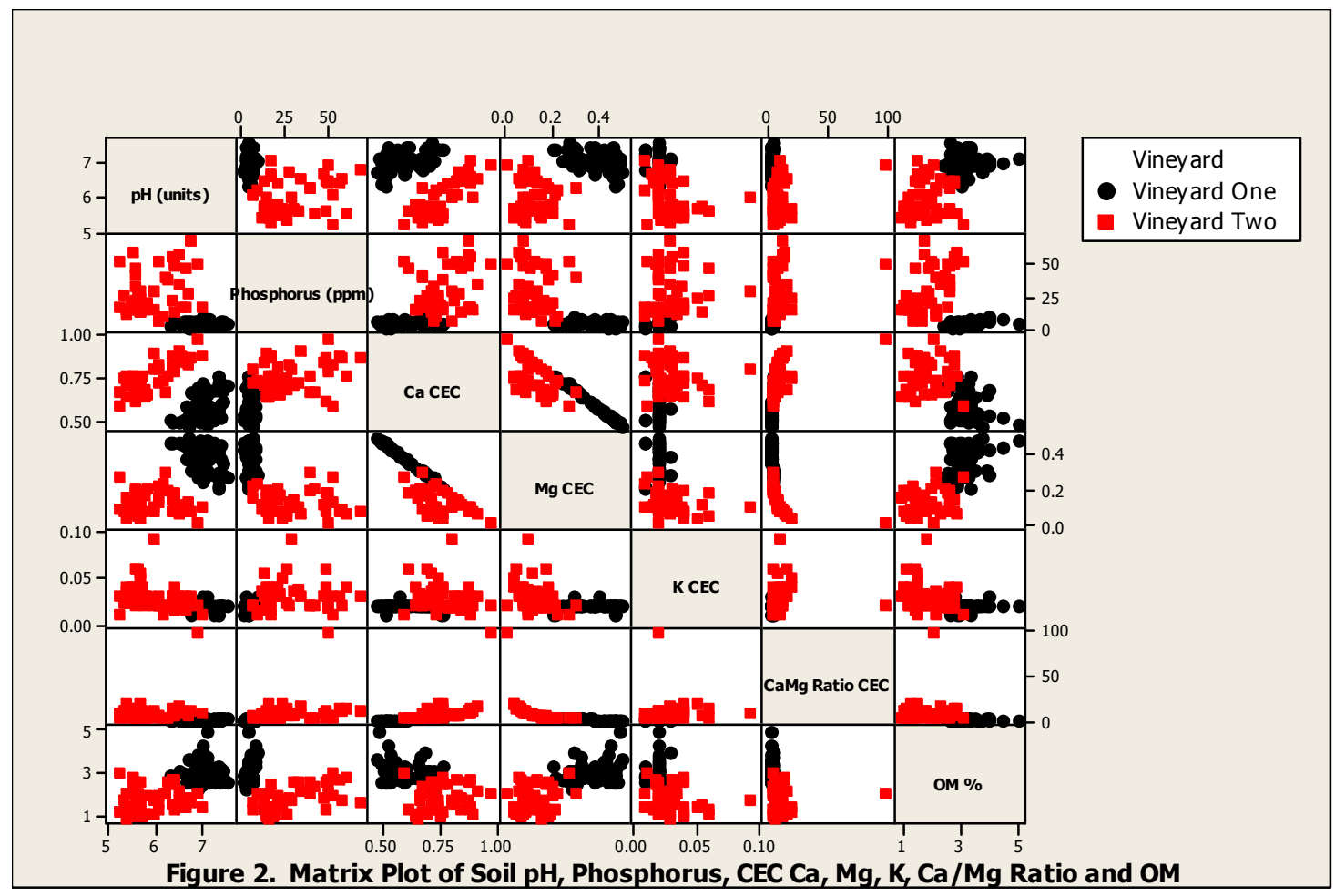

pH

Soil $\mathrm{pH}$ identifies whether a soil is acidic $(\mathrm{pH}<7.0)$, neutral $(\mathrm{pH} 7.0)$ or basic $(\mathrm{pH}>7.0)$ and plays a role in nutrient availability. Soils in this project were categorized as acidic (Vineyard 2) and neutral (Vineyard 2).

Soil pH values did not change significantly over the study (Table 2 and Table 3). However, there was statistically significant difference $(P<0.001)$ between vineyards in 
terms of their mean soil pH values. At Vineyard One, pre-treatment soil samples had, on average, a $\mathrm{pH}$ value of 6.98 (Figure 3). Following treatment, $\mathrm{pH}$ values increased to 7.13. At Vineyard Two, pre-treatment soil samples had, on average, a $\mathrm{pH}$ value of 6.04 and following treatment a $\mathrm{pH}$ value of 5.93 .

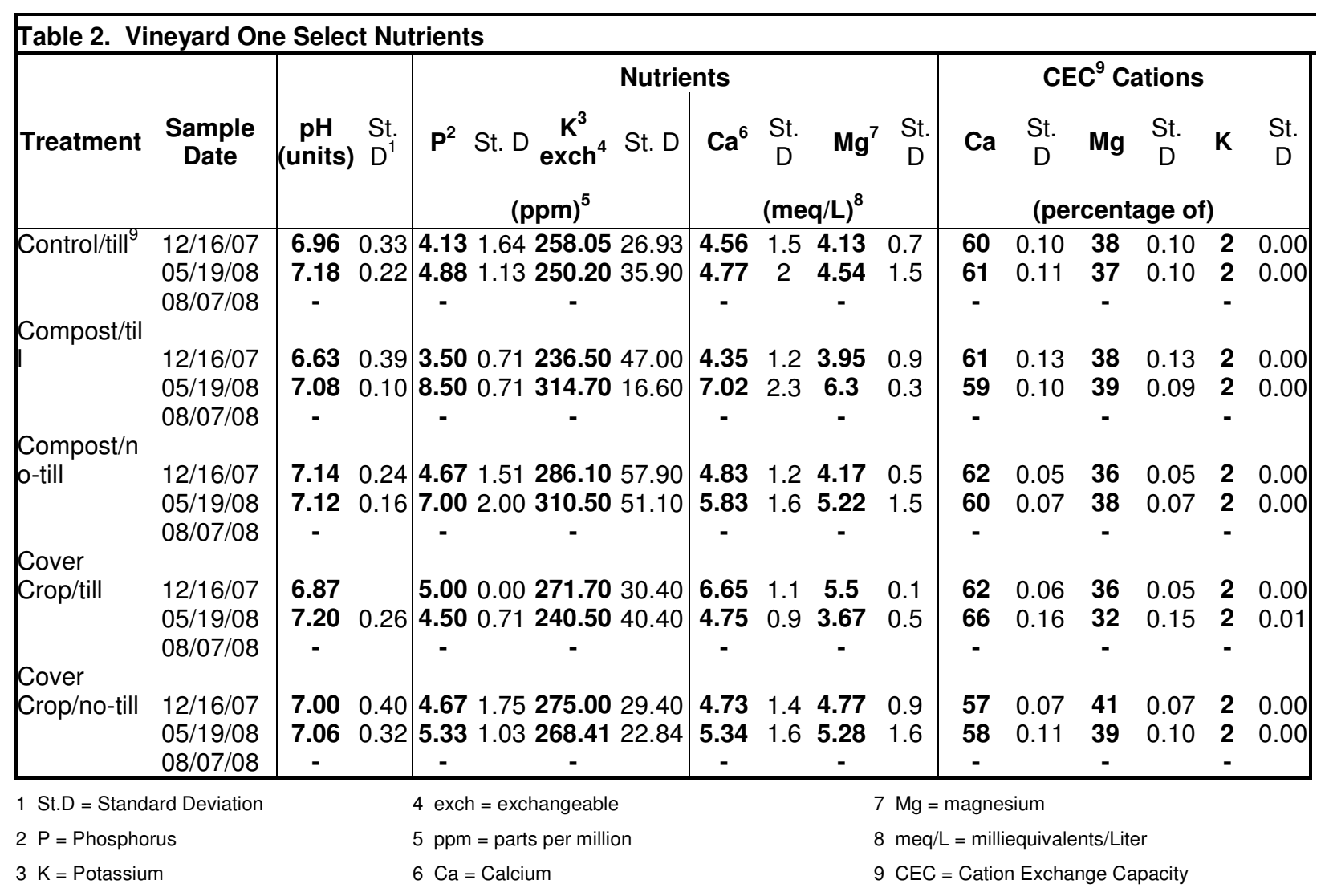




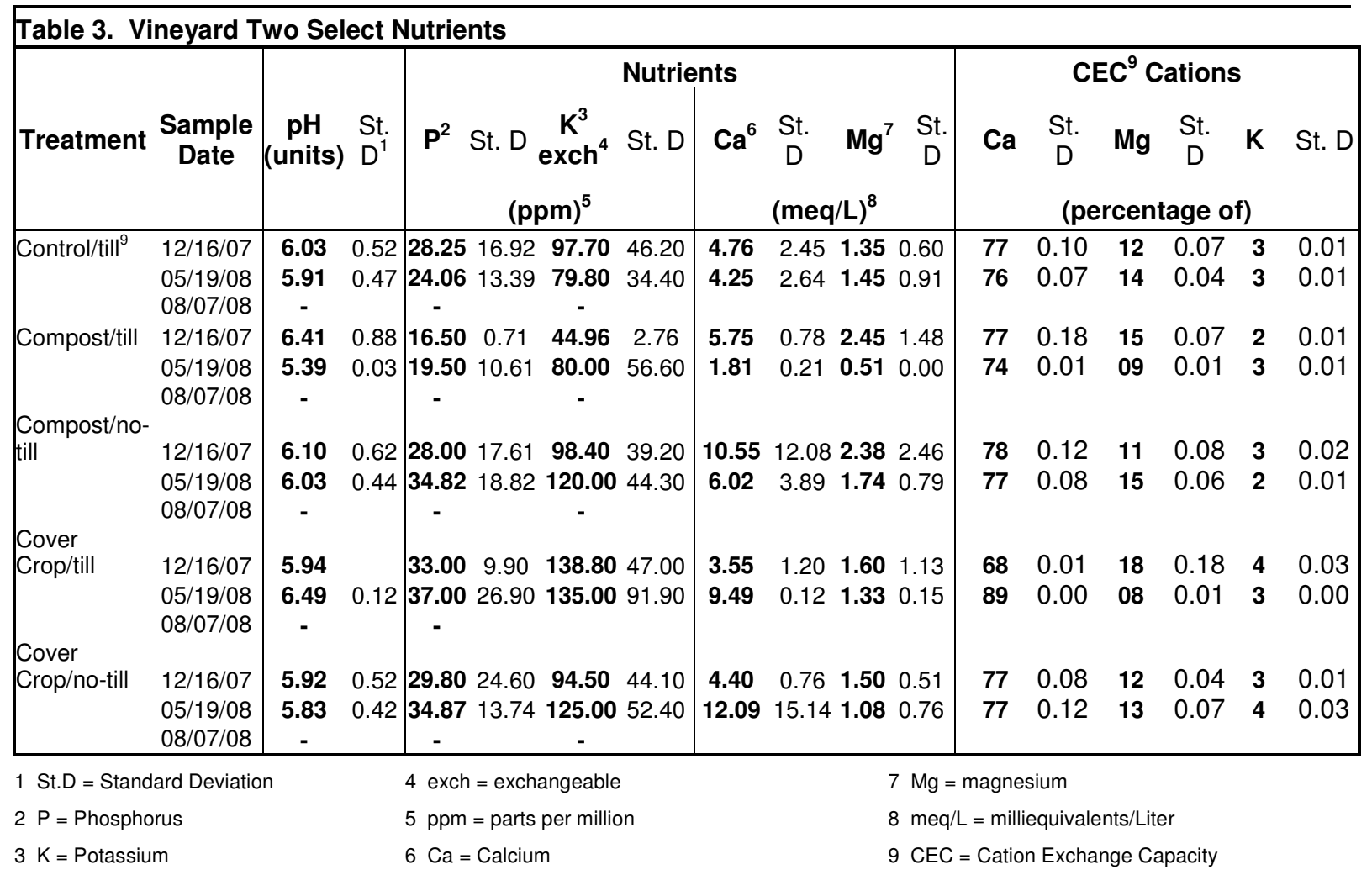

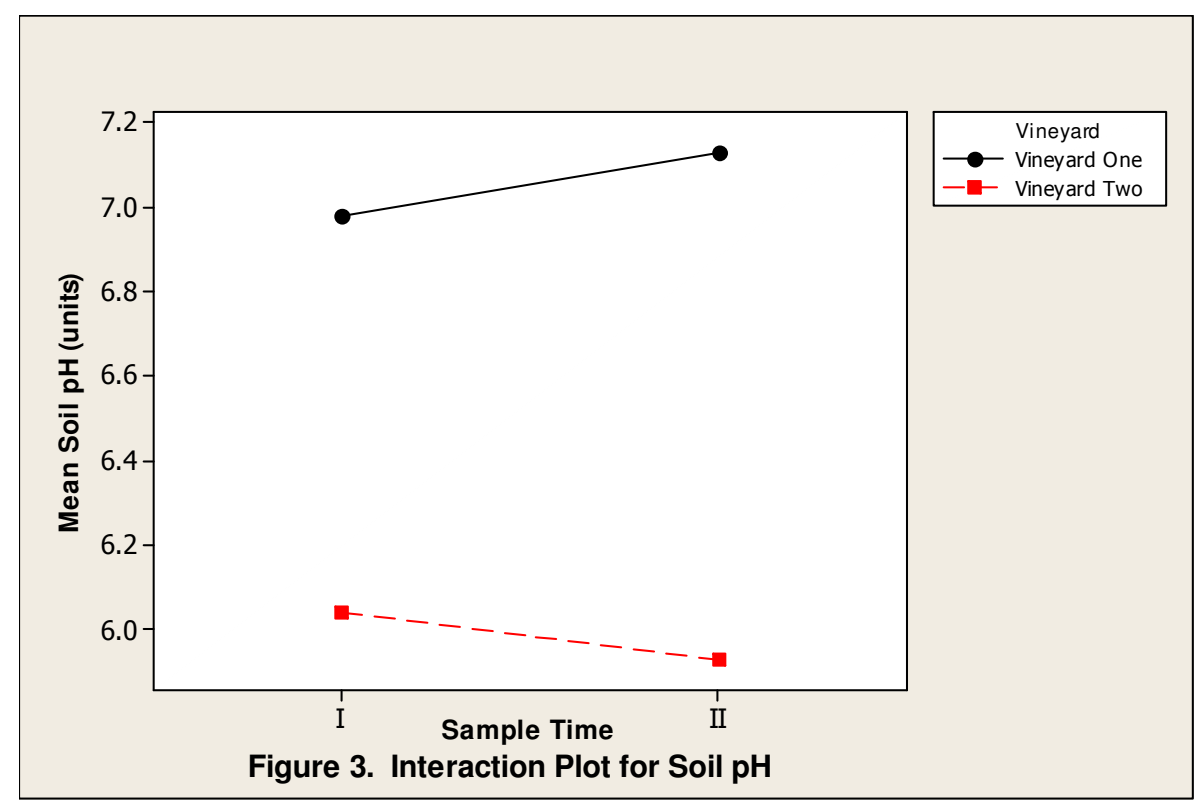

There was a significant difference $(P=0.017)$ between blocks within vineyards in terms of their mean soil pH value. This was more apparent in Vineyard Two (Figure 4). 
There was also a significant difference, $(P=0.004)$, between Sub-blocks $(A$ and B), hence north and south, within blocks (I, II, III, and IV) in terms of their mean soil pH (Figure 4). Generally, mean soil pH values were slightly higher in Sub-block A.

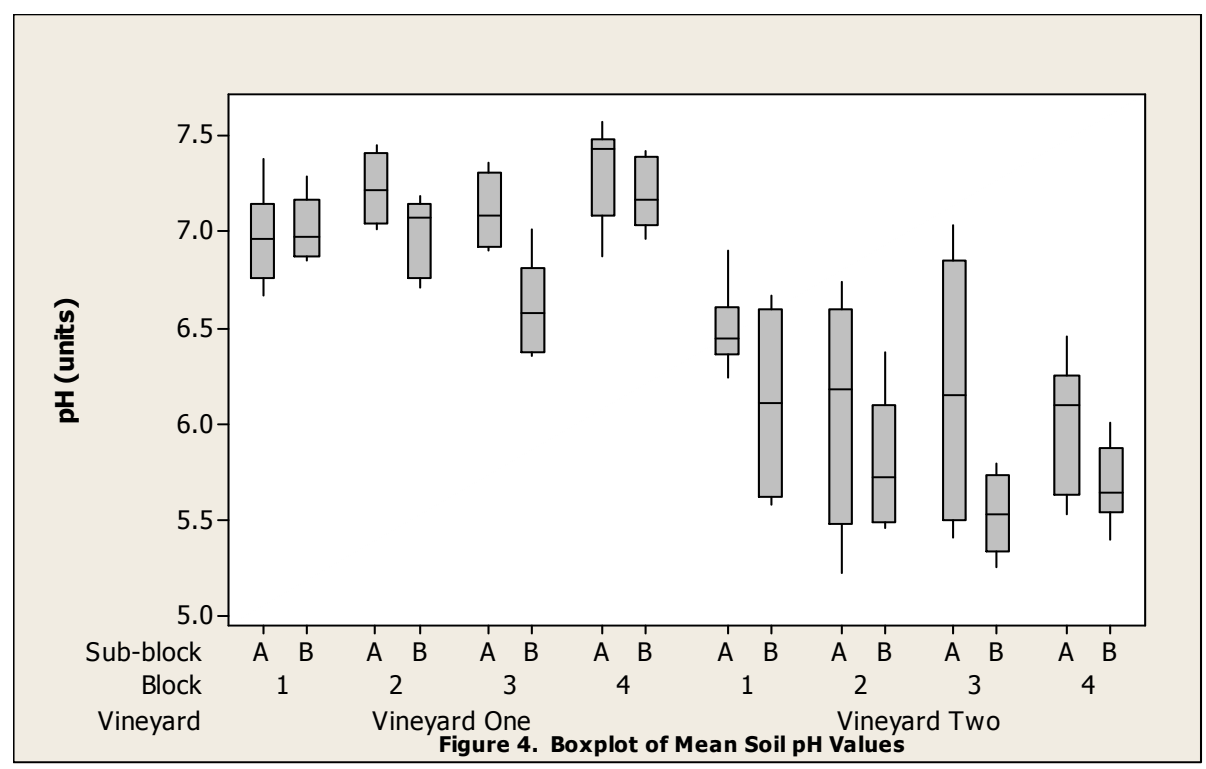

There was little change between treatment areas and their effects on $\mathrm{pH}$ at both vineyards. At Vineyard One, soil pH increased slightly in all treatment areas except in the compost/no-till area (Figure 5). Post-treatment, the compost/till mean soil $\mathrm{pH}$ increased by $7 \%$ and the compost/no-till area average soil $\mathrm{pH}$ remained the same. In the cover crop areas the $\mathrm{pH}$ increased by $5 \%$ (till) and 1\% (no-till). The control/till area soil increased $\mathrm{pH}$ by 3\%. At Vineyard Two, soil pH decreased slightly in all areas except cover crop/till (Figure 6). Soils collected from the compost areas decreased 16\% (tilled) and $1 \%$ (no-till). Soils from the cover crop/till area increased by $9 \%$ and decreased by $2 \%$ in the no-till area. Soil from the control/till area decreased by $3 \%$. 

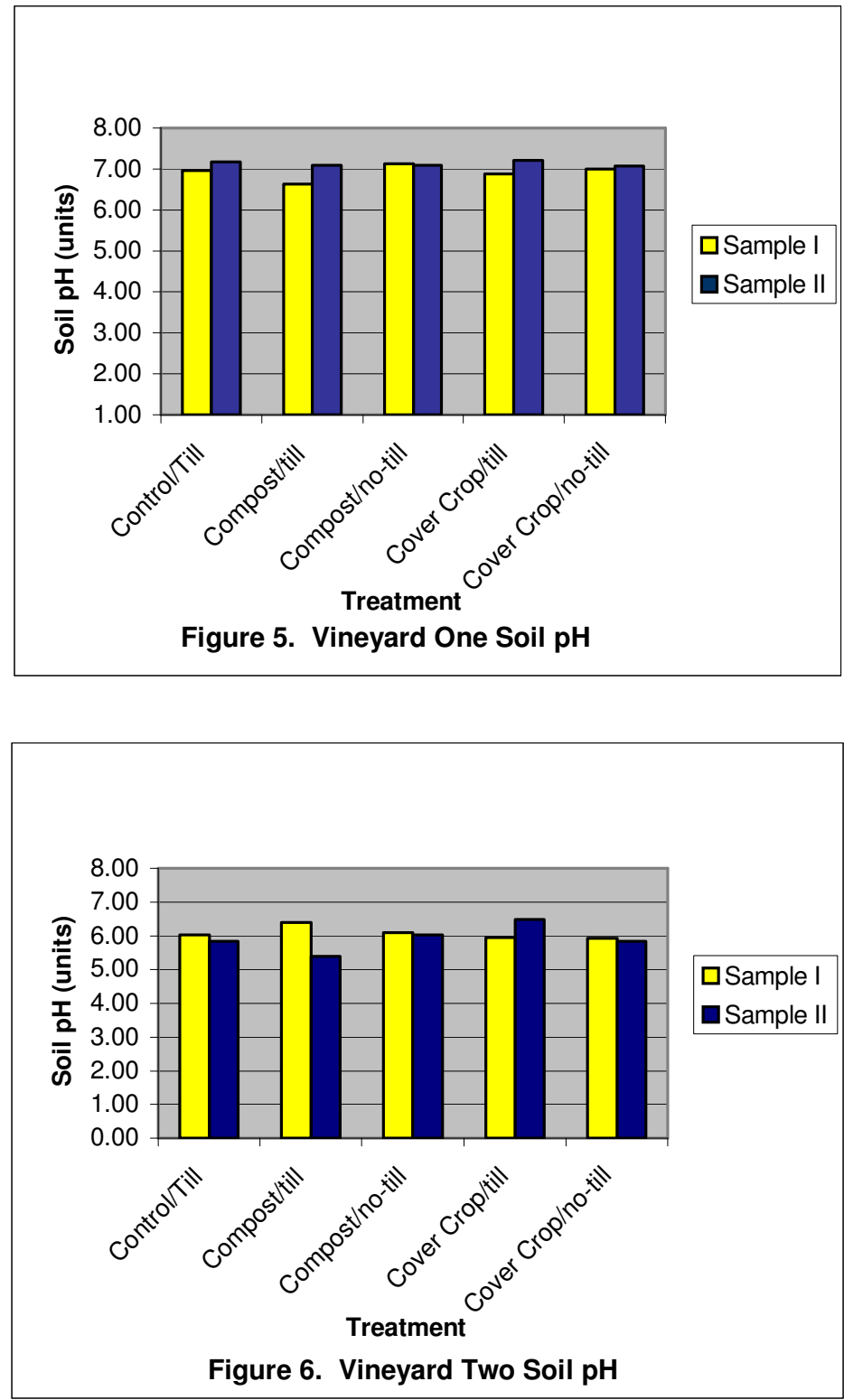

There were no significant interactions found between: 1) vineyard and sampling time, 2) treatment/till and vineyard, or 3) treatment/till and sampling time on soil $\mathrm{pH}$. 


\section{Nutrients}

\section{Phosphorus}

Phosphorus is an important soil nutrients required for vines. In the soil $\mathrm{P}$ is relatively immobile. Optimum levels of $\mathrm{P}$ in vineyard soils are between 35 and $80 \mathrm{ppm}^{8}$.

Phosphorus concentrations increased in both vineyards during the project and increased in all the treatment areas except the bare/control in Vineyard Two. There was a significant difference $(P<0.001)$ between vineyards in terms of their mean soil $P$ concentrations (Figure 7). Vineyard Two had consistently higher percentages of soil P than Vineyard One. Prior to treatment, soil samples from Vineyard One contained on average 4.42 ppm P and Vineyard Two contained on average 28 ppm P. Post-treatment samples contained, on average, 5.79 ppm $P$ in Vineyard One and 30.15 ppm $P$ in Vineyard Two.

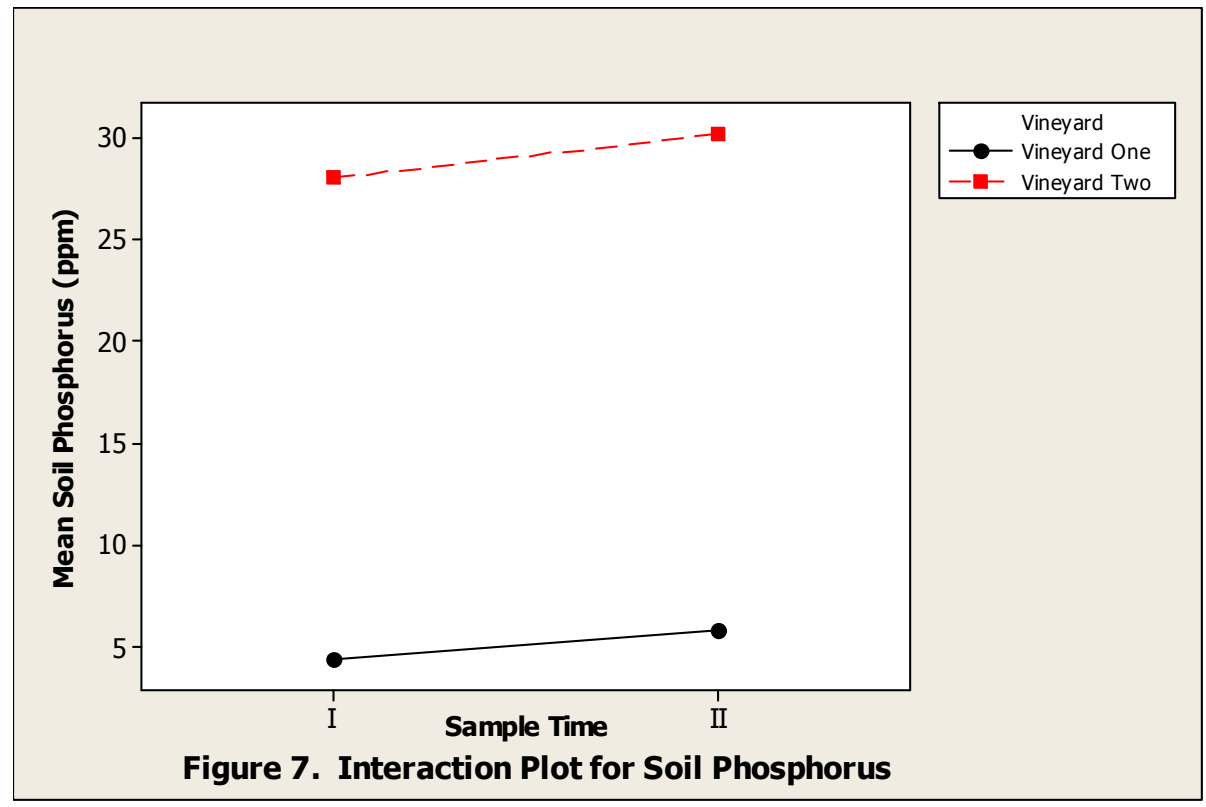

At Vineyard One, soil P concentrations increased more in the soils collected from the compost areas, both tilled (143\%) and no-till (50\%), than those from the cover crop areas (tilled- decrease 10\%, no-till- increase 14\%) or control/till (18\%) (Figure 8). At

\footnotetext{
${ }^{8}$ Optimum soil nutrient levels obtained from Steve Vierra, Vineyard Professional Services, Inc.
} 
Vineyard Two, soil P increased in all areas except the control/till where it decreased (Figure 9). Soils collected from the compost areas increased 18\% (tilled) and 24\% (notill). Soils from the cover crop areas increased by $12 \%$ (till) and $17 \%$ (no-till). Soil from the control/till area decreased by $15 \%$.
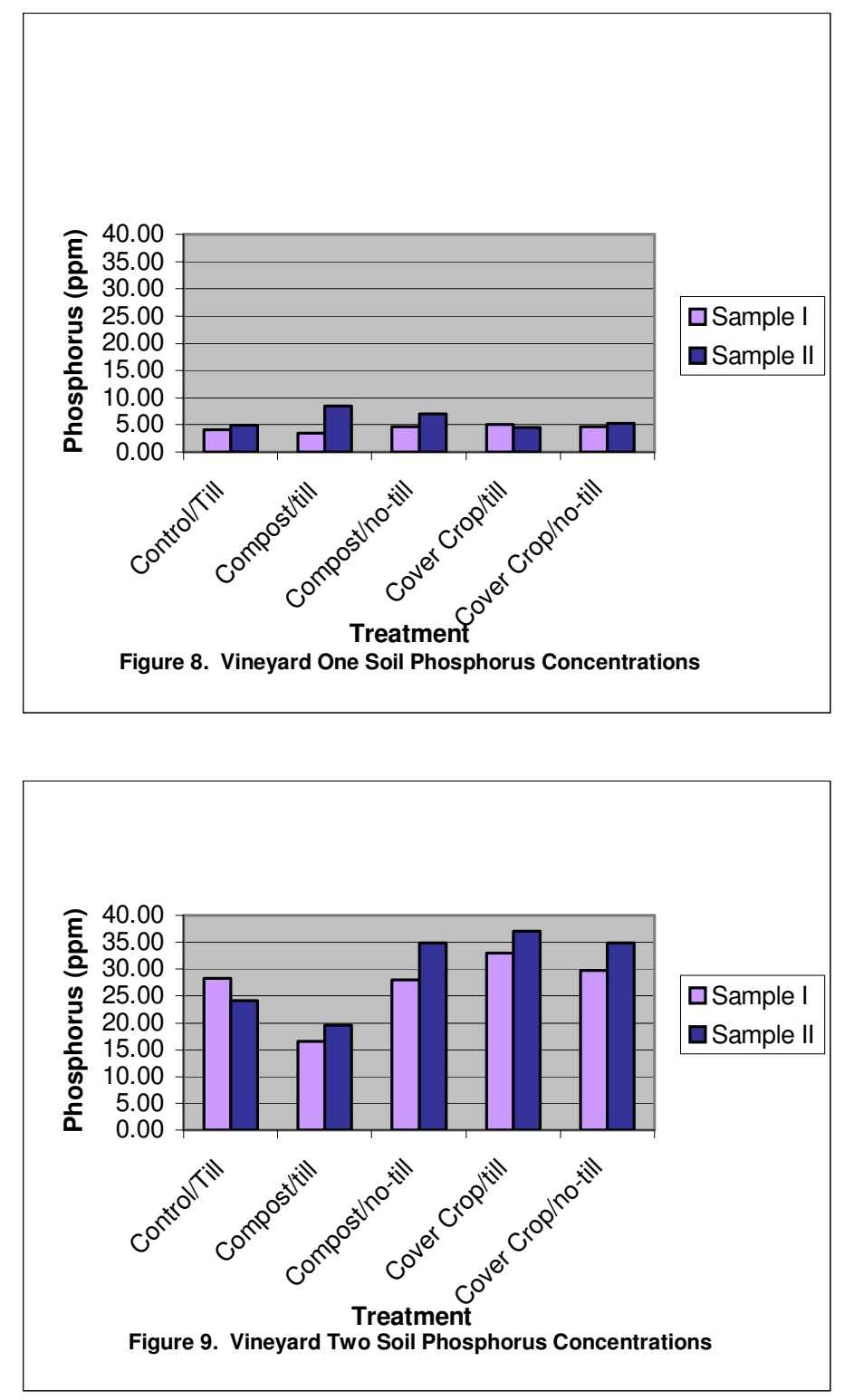

There was also a statistically significant difference, $(P<0.001)$, between Subblocks (A and B), hence upper and lower half, in terms of their mean soil $\mathrm{P}$ concentrations (Figure 10) within blocks (I, II, III, and IV). This was more apparent in 
Vineyard Two where mean $P$ values were higher in Sub-block $A$ in three of the four Blocks.

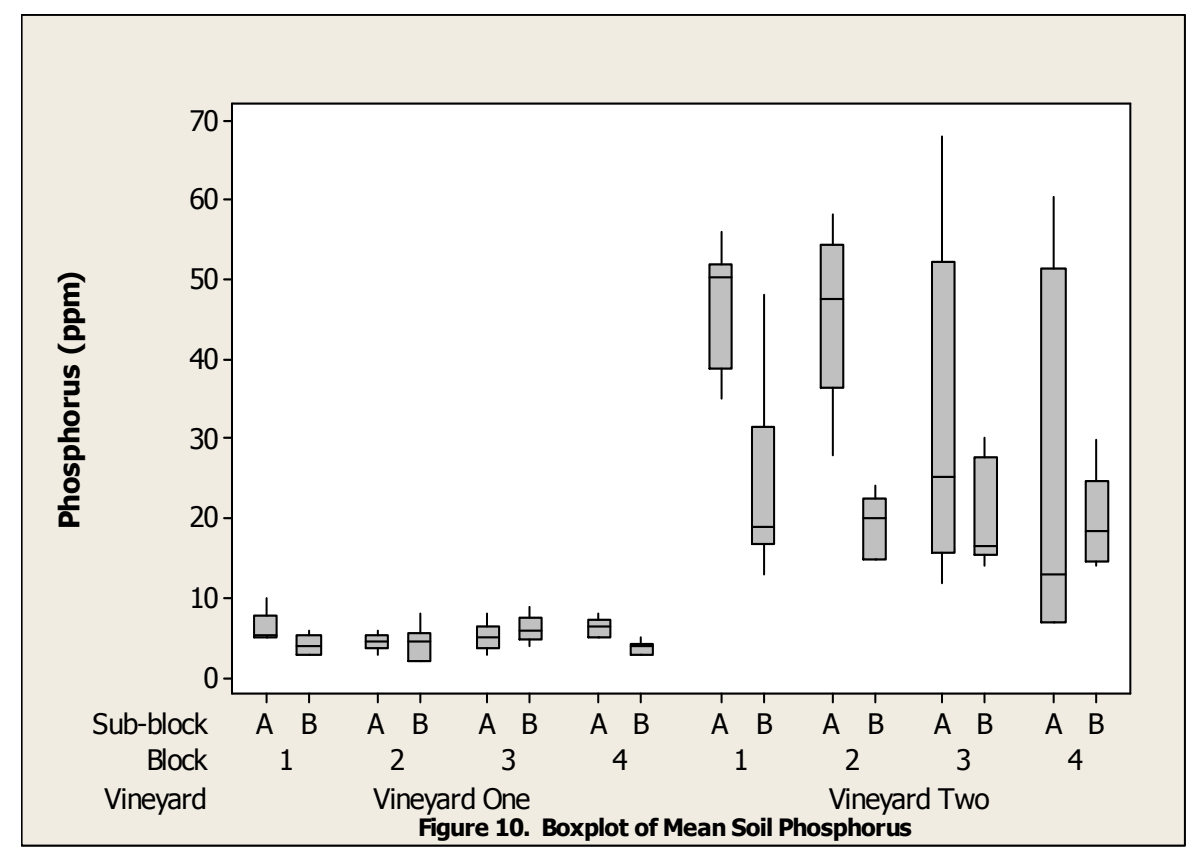

There were no significant interactions found between: 1) vineyard and sampling time, 2) treatment/till and vineyard, or 3) treatment/till and sampling time on soil $P$. However, there was more of an effect from treatment on soil $P$ concentrations in Vineyard Two than in Vineyard One (Figure 10).

\section{Potassium}

Exchangeable $\mathrm{K}$ is one potentially available form of $\mathrm{K}$ found in soil.

There was a statistically significant difference $(P<0.001)$ between vineyards in terms of their mean soil $\mathrm{K}$ concentrations. Vineyard One had consistently higher concentrations of soil K than Vineyard Two (Figure 11). Soils from Vineyard One contained $268.68 \mathrm{ppm} \mathrm{K}$ prior to treatment and following treatment contained $274 \mathrm{ppm}$ K. Soils from Vineyard Two contained $96.12 \mathrm{ppm} \mathrm{K} \mathrm{prior} \mathrm{to} \mathrm{treatment} \mathrm{and} 105.75 \mathrm{ppm} \mathrm{K}$ following treatments. 


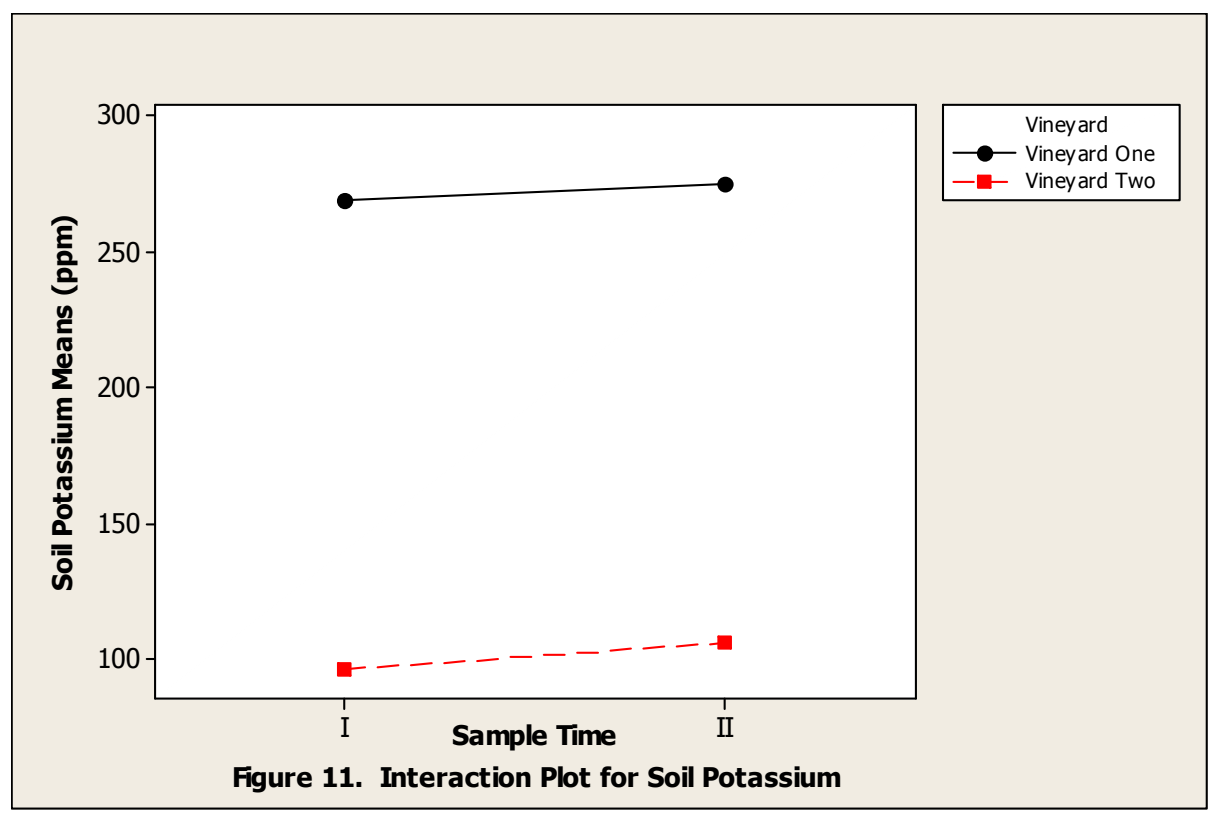

There was a significant effect $(P=0.019)$ from treatments on soil $K$ concentrations, that is treatments had different effects on mean soil $\mathrm{K}$ concentrations. At Vineyard One, soil $\mathrm{K}$ increased more in the soils collected from the compost areas, both tilled (33\%) and no-till (9\%), than those from the cover crop areas (tilled- decrease $11 \%$, no-till- decrease 2\%) or control/till (decrease 3\%) (Figure 12). At Vineyard Two, soil K increased in most areas (Figure 13). Soils collected from the compost areas increased $78 \%$ (tilled) and $22 \%$ (no-till). Soils from the cover crop areas decreased by $3 \%$ (till) and increased $32 \%$ (no-till). Soil from the control/till area decreased by $18 \%$.

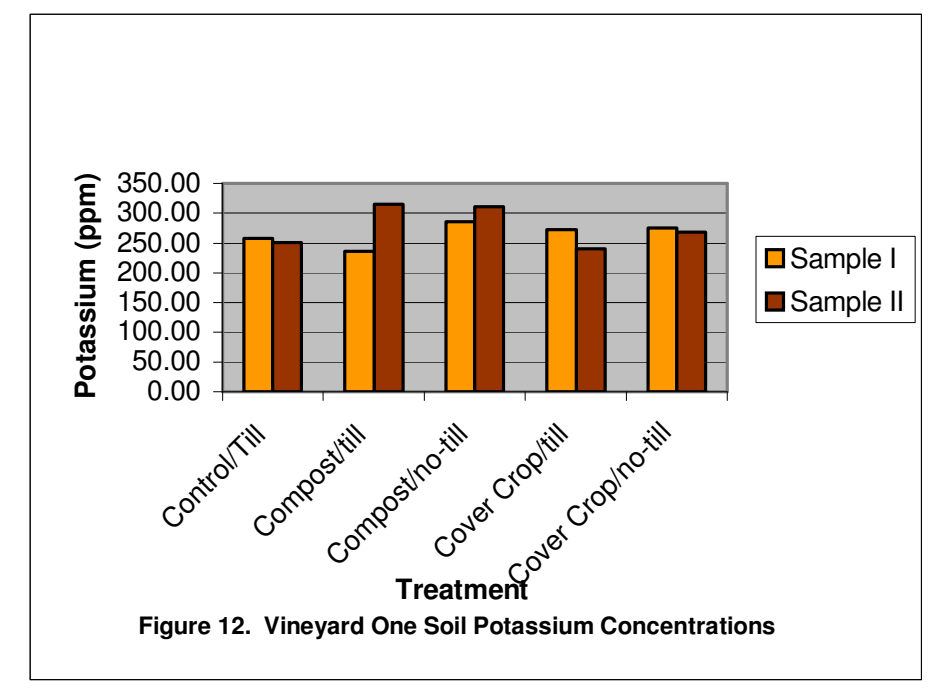




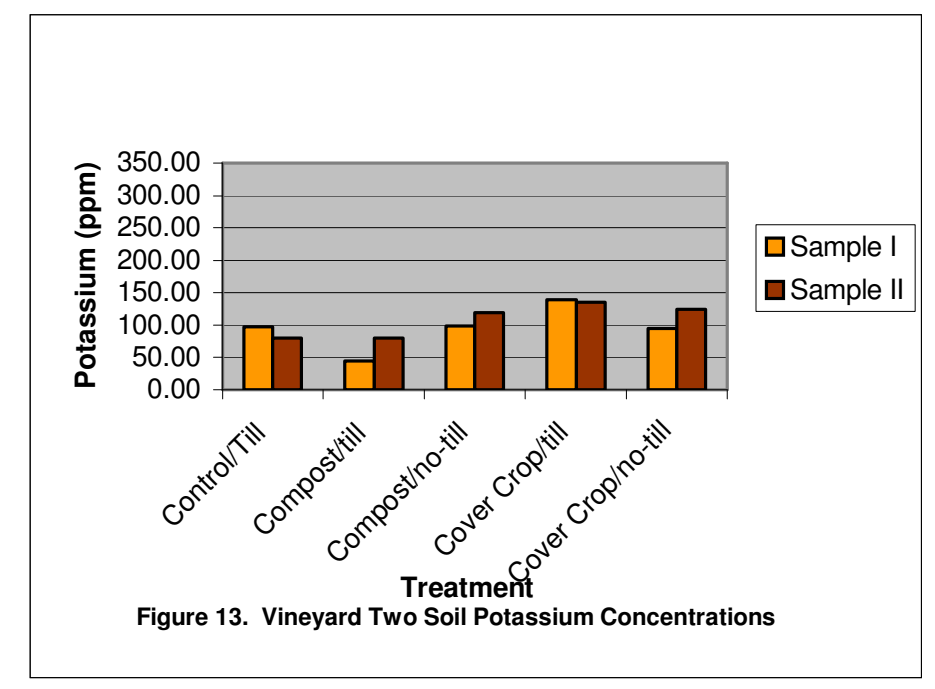

There was also a statistically significant difference, $(P=0.045)$, between Subblocks ( $\mathrm{A}$ and $\mathrm{B}$ ), hence upper and lower half, in terms of their mean soil $\mathrm{K}$ concentrations (Figure 14) within blocks (I, II, III, and IV). At Vineyard One, soil K concentrations were generally higher in Sub-block B than in Sub-block A. The opposite was true at Vineyard Two, where soil K concentrations were generally higher in Subblock $A$ than in Sub-block B.

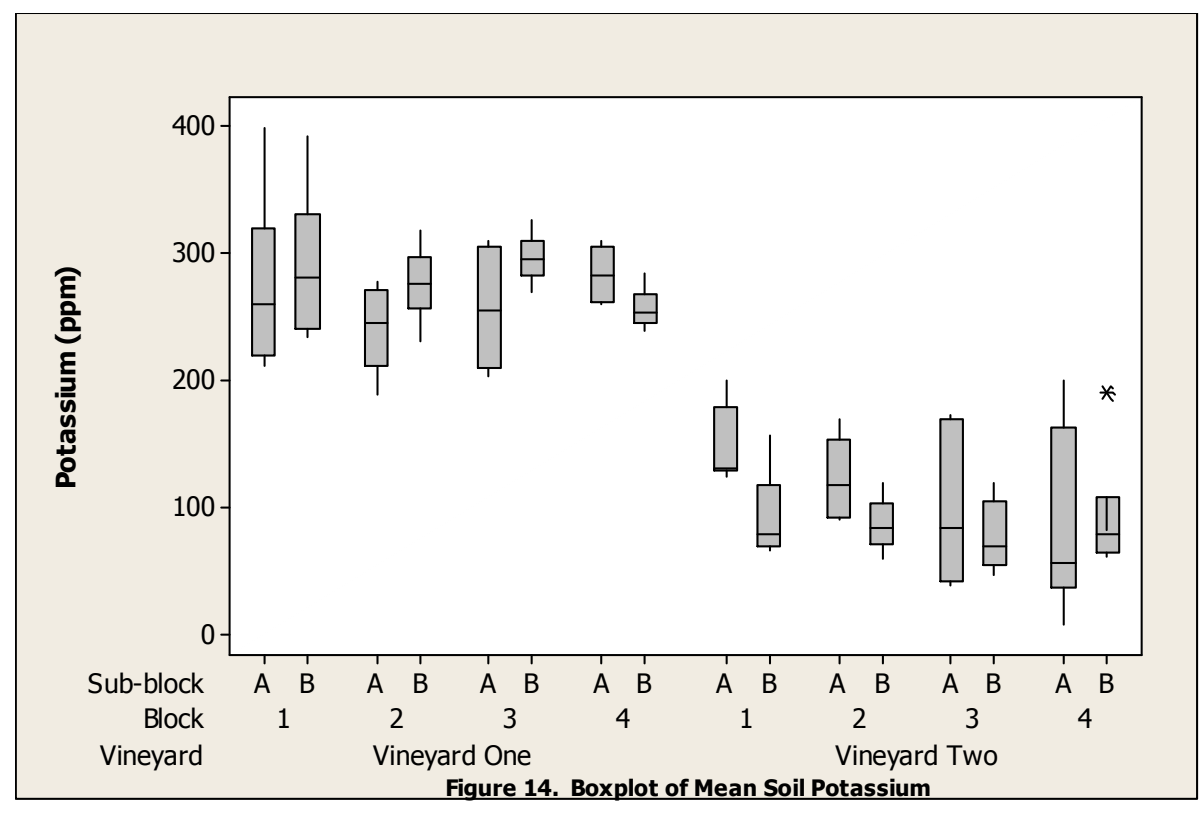

There were no significant interactions found between: 1) vineyard and sampling time, 2) treatment/till and vineyard, or 3) treatment/till and sampling time on soil $\mathrm{K}$. 


\section{Soluble Calcium}

Soluble calcium is the most readily available form of calcium to plants.

There was a difference $(P<0.001)$ between vineyards and soluble $\mathrm{Ca}$ concentrations. Vineyard One had consistently lower concentrations of $\mathrm{Ca}$ than Vineyard Two (Figure 15). Soils from Vineyard One contained 4.83 milliequivalents/Liter (meq/L) Ca prior to treatment and following treatment contained $5.36 \mathrm{meq} / \mathrm{L}$ Ca. Soils from Vineyard Two contained $6.10 \mathrm{meq} / \mathrm{L} \mathrm{Ca}$ prior to treatment and $6.89 \mathrm{Ca}$ following treatments.

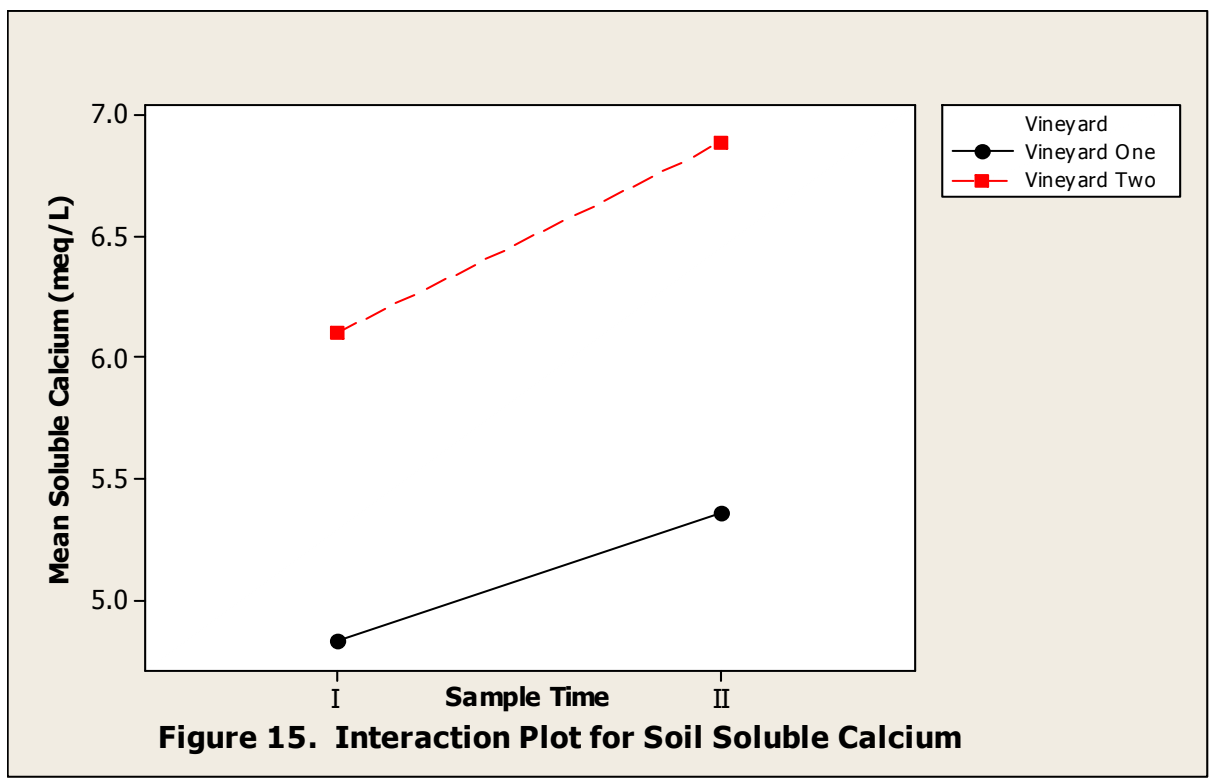

There was no significant difference between treatment areas and their affects on

$\mathrm{Ca}$ at both vineyards. At Vineyard One, soil $\mathrm{Ca}$ increased slightly in all treatment areas except in the cover crop/till area (Figure 16). Post-treatment, the compost/till area (average) soil $\mathrm{Ca}$ increased by $61 \%$ and the compost/no-till area average soil $\mathrm{Ca}$ increased by $21 \%$. In the cover crop areas the Ca decreased by $29 \%$ (till) and increased by $13 \%$ (no-till). The control/till area soil increased Ca by $5 \%$. In Vineyard Two, Ca concentrations increased in the compost areas but decreased in the cover crop areas (Figure 17). Soils collected from the compost areas decreased by $69 \%$ (tilled) and $43 \%$ 
(no-till). Soils from the cover crop/till area increased by $167 \%$ and $175 \%$ in the no-till area. Soil from the control/till area decreased by $11 \%$.
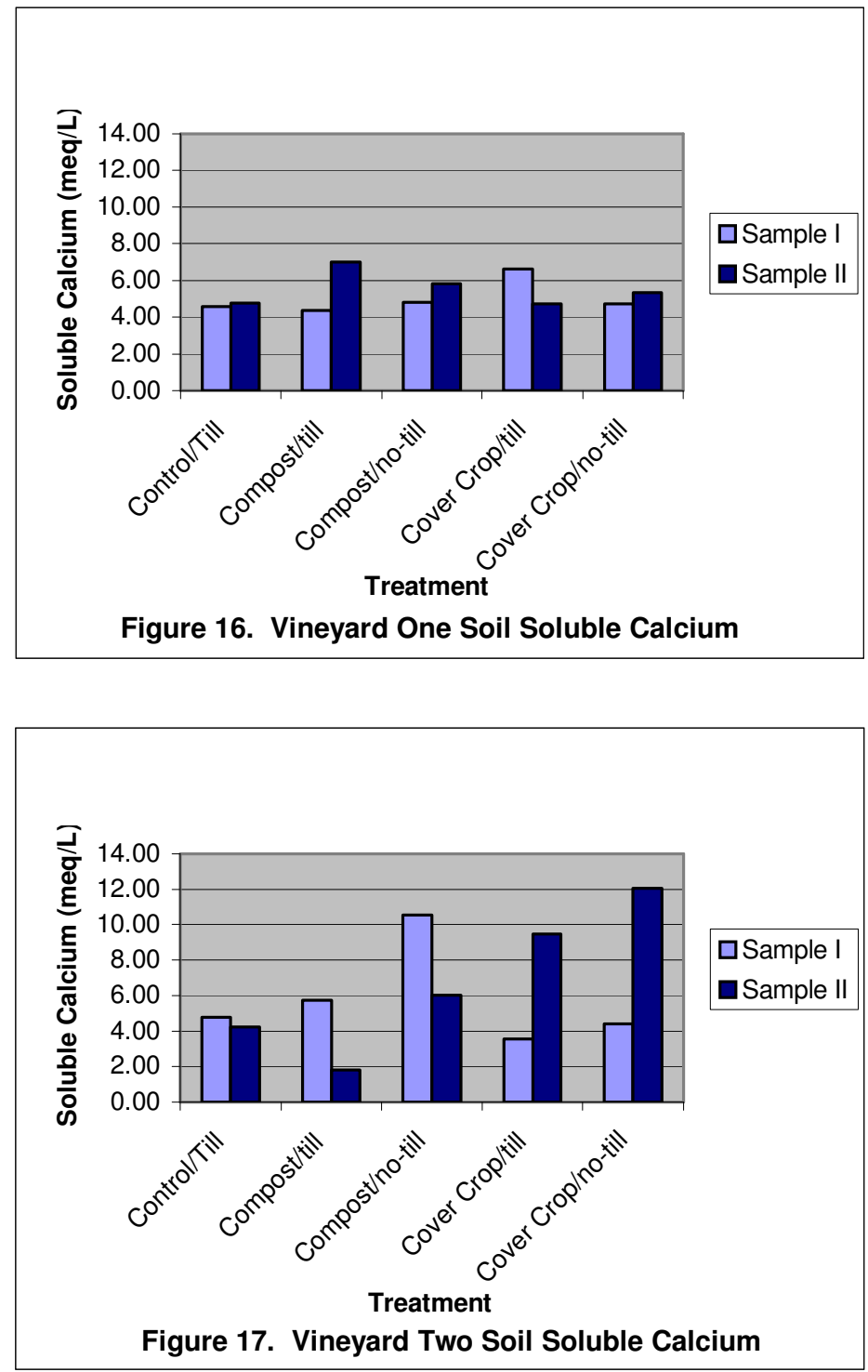

There was a significant difference $(P=0.004)$ between blocks within vineyards in terms of their mean soil soluble Ca concentrations (Figure 18). This was more apparent at Vineyard Two. 


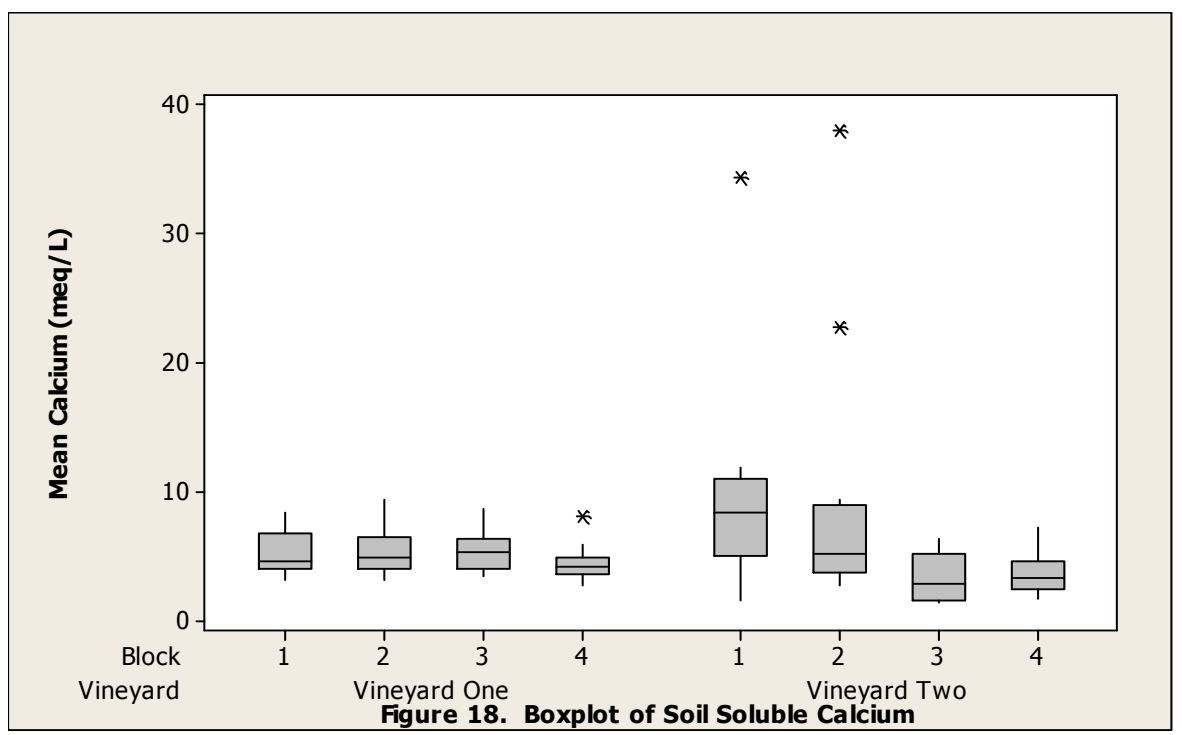

\section{Soluble Magnesium}

Soluble magnesium is the most readily available form of magnesium for plants.

There was a statistically significant difference $(P<0.001)$ between vineyards in terms of their mean soil soluble Mg concentrations. Vineyard One had consistently higher concentrations of Mg than Vineyard Two (Figure 19). Soils from Vineyard One contained, on average, $4.40 \mathrm{meq} / \mathrm{L} \mathrm{Mg}$ prior to treatment and following treatment contained $4.97 \mathrm{meq} / \mathrm{L} \mathrm{Mg}$. Soils from Vineyard Two contained $1.76 \mathrm{meq} / \mathrm{L} \mathrm{Mg}$ prior to treatment and $1.34 \mathrm{meq} / \mathrm{L} \mathrm{Mg}$ following treatments.

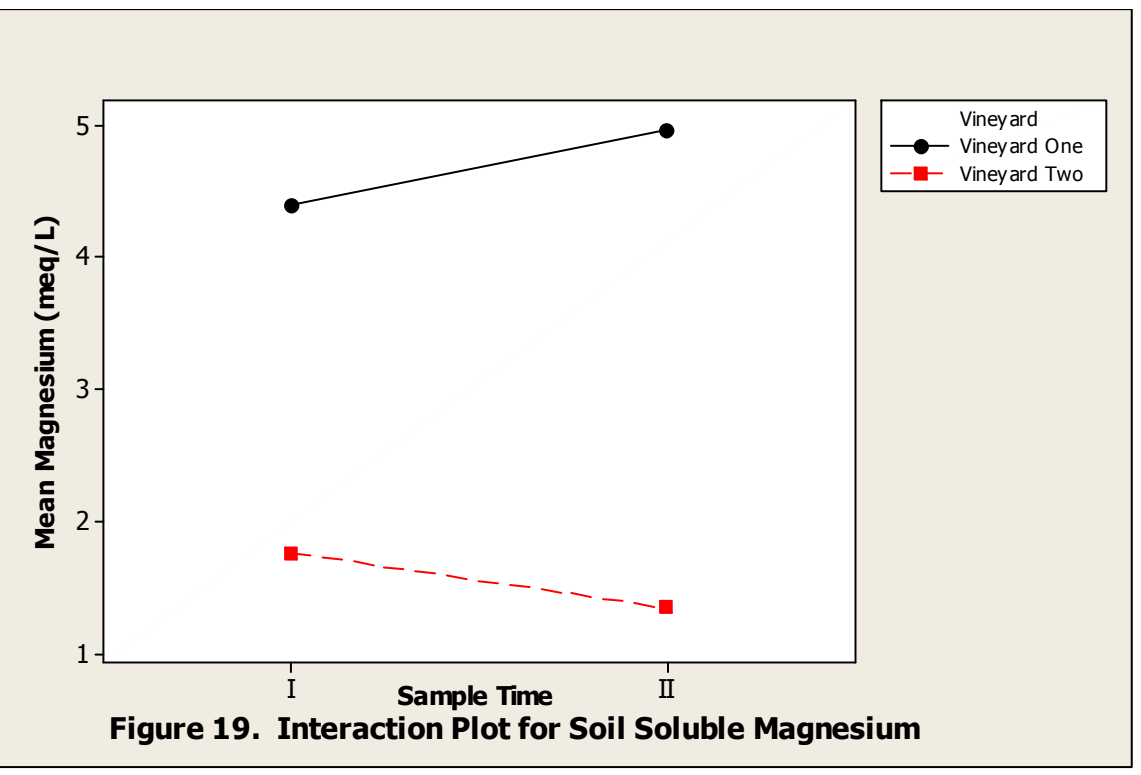


There was no significant difference between treatment areas and their effects on Mg at both vineyards. At Vineyard One, soil Mg increased in all treatment areas except in the cover crop/till area (Figure 20). Post-treatment, the compost/till area (average) soil $\mathrm{Mg}$ increased by $59 \%$ and the compost/no-till area average soil Mg increased by $25 \%$. In the cover crop areas the Mg decreased by $33 \%$ (till) and increased by $11 \%$ (notill). The control/till area soil increased Mg by $10 \%$. In Vineyard Two, Mg concentrations decreased in areas except the control (Figure 21). Soils collected from the compost areas decreased by $79 \%$ (tilled) and $27 \%$ (no-till). Soils from the cover crop/till area decreased by $17 \%$ and $28 \%$ in the no-till area. Soil from the control/till area increased by $7 \%$.

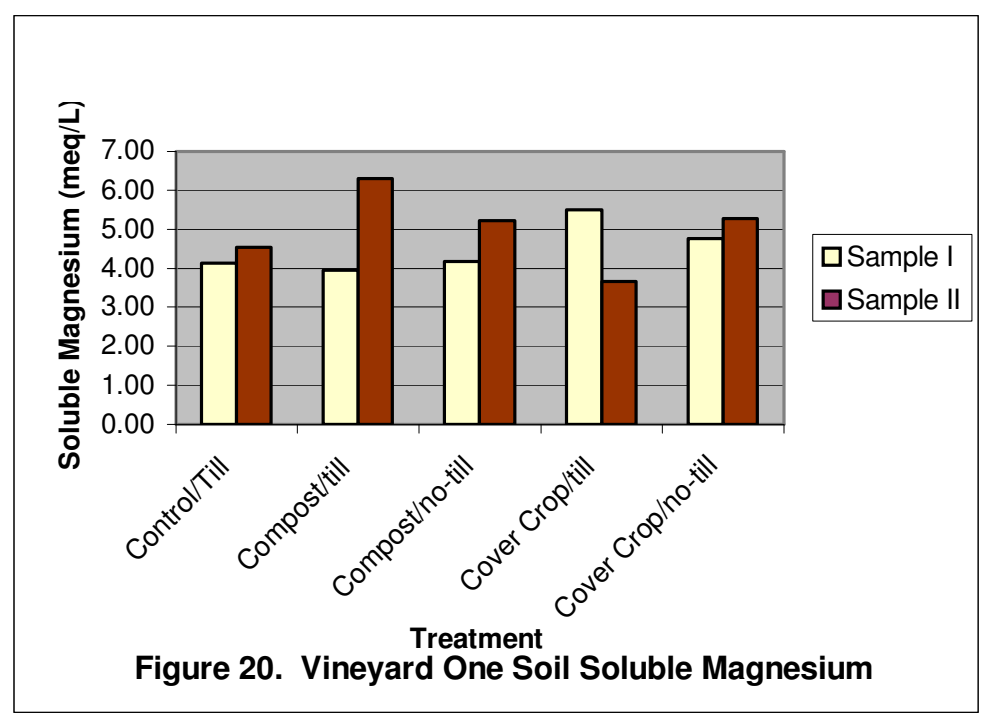




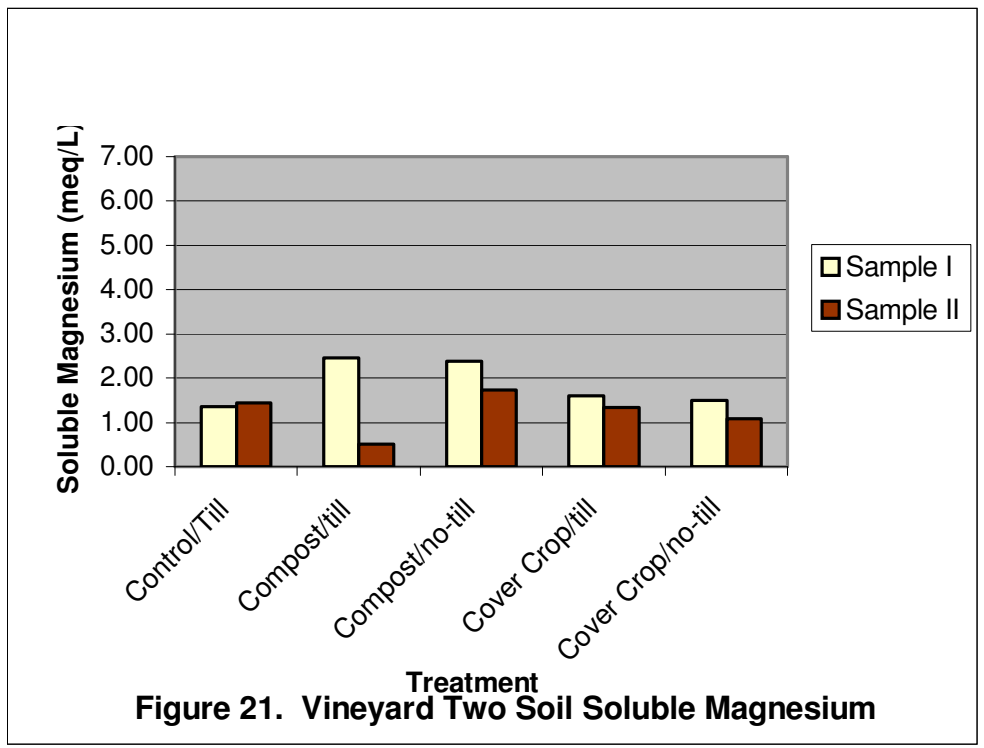

There was a significant interaction between vineyard and sample time $(P=$ 0.044). That is, the vineyards changed over time differently in their concentrations of soluble magnesium (Figure 22). At Vineyard One, mean soil soluble Mg concentrations increased post-treatment. At Vineyard Two, mean soil soluble Mg concentrations decreased post-treatment.

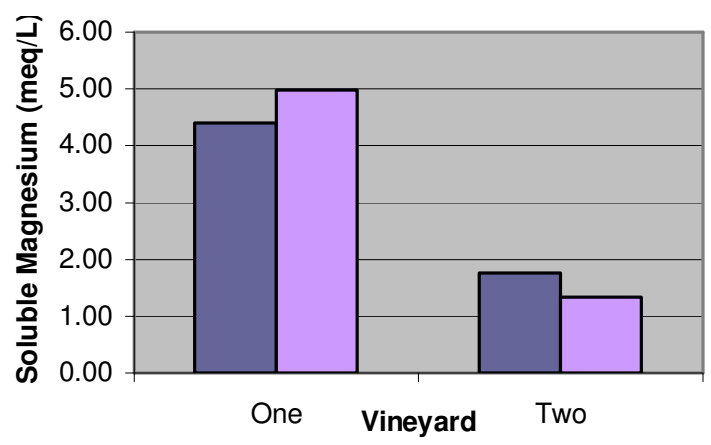

口Sample I $\square$ Sample II

Figure 22. Mean Soil Soluble Mg Concentrations

\section{CEC Exchangeable Cations}

\section{Percentage of Exchangeable Calcium}

There was a statistically significant difference $(P<0.001)$ between vineyards in terms of their mean soil CEC exchangeable Ca concentrations. Vineyard Two had 
consistently higher concentrations of CEC exchangeable Ca than Vineyard One (Figure 23). Soils from Vineyard One contained $60 \% \mathrm{Ca}$ prior to treatment and following treatment contained $60 \%$ Ca. Soils from Vineyard Two contained $76 \%$ Ca prior to treatment and $77 \%$ Ca following treatments.

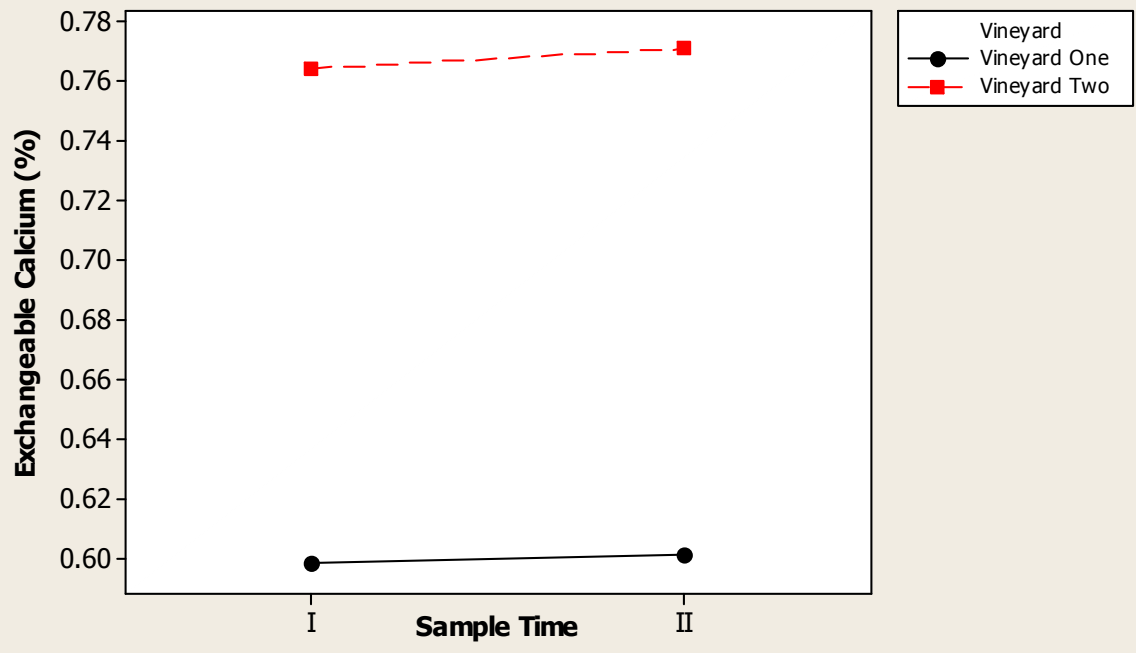

Figure 23. Interaction Plot for Mean Soil Exchangeable Calcium

There was no significant difference between treatment areas and their effects on exchangeable Ca\% at both vineyards. At Vineyard One, exchangeable Ca\% decreased in the both compost areas by $3 \%$. Exchangeable $\mathrm{Ca}$ in the cover crop areas increased by $6 \%$ (till) and $2 \%$ (no-till) (Figure 24). The control/till area soil increased Ca by $2 \%$. There was no trend in Vineyard Two (Figure 25). Soils collected from the compost areas decreased exchangeable Ca\% by $4 \%$ (tilled) and $1 \%$ (no-till). Soils from the cover crop/till area increased by exchangeable Ca\% by $31 \%$ (till). No change was found in soil Ca\% in the cover crop no-till area. Soil from the control/till area decreased by $1 \%$. 

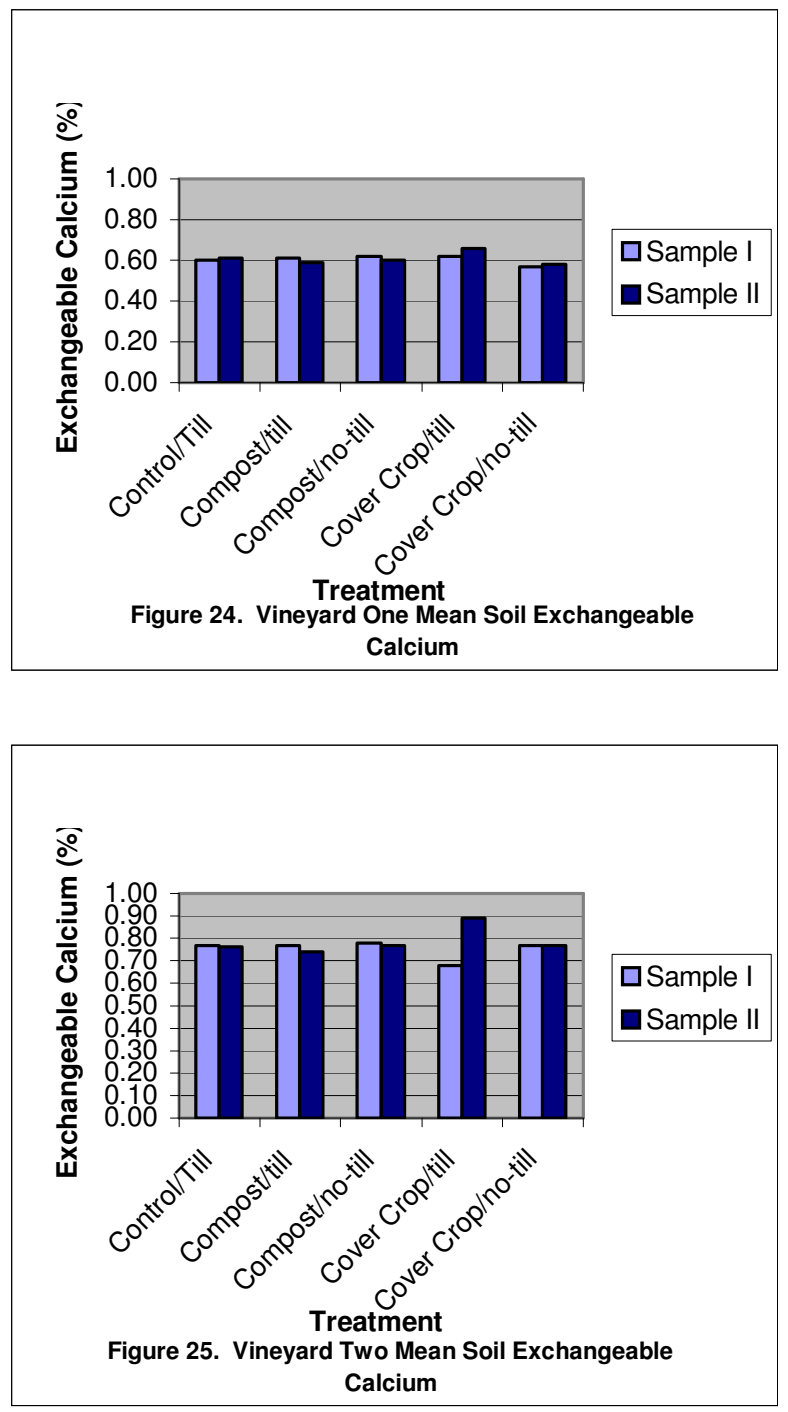

There was a significant difference $(P=<0.001)$ between blocks within vineyards in terms of their mean soil exchangeable Ca concentrations (Figure 26). That is, there was variability between the blocks nested within the vineyards. 


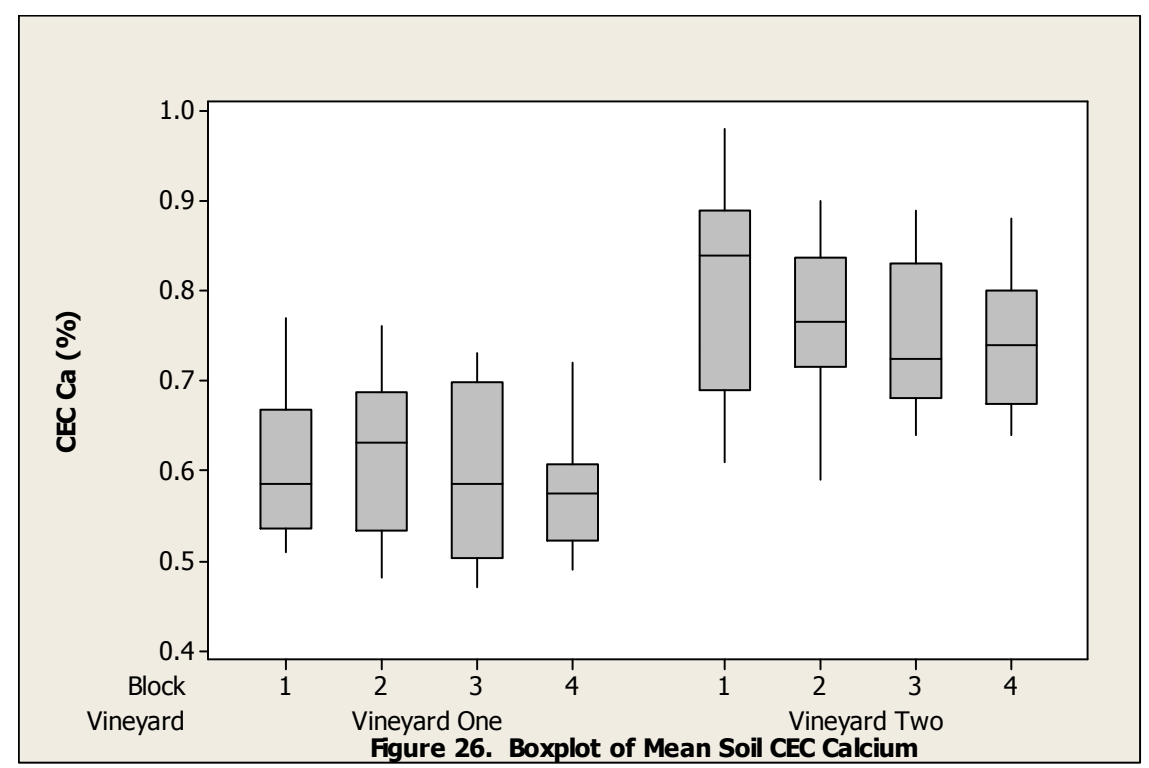

\section{Percentage of Exchangeable Magnesium}

There was a statistically significant difference $(P<0.001)$ between vineyards in terms of their mean soil exchangeable Mg concentrations. Vineyard One had consistently higher concentrations of exchangeable Mg than Vineyard Two (Figure 27). Soils from Vineyard One contained $38 \% \mathrm{Mg}$ prior to treatment and following treatment contained $37 \%$ Mg. Soils from Vineyard Two contained $12 \%$ Mg prior to treatment and $13 \% \mathrm{Mg}$ following treatments.

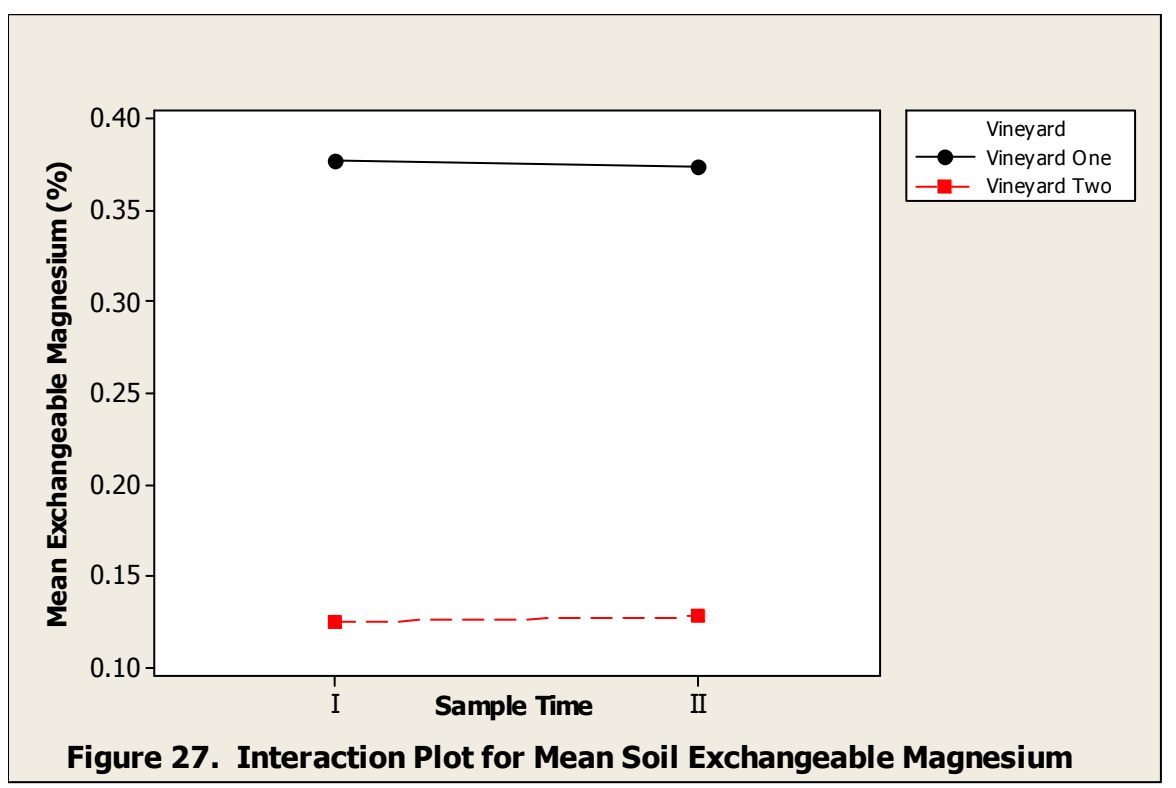


There was no significant difference between treatment areas and their effects on exchangeable Mg\% at both vineyards. At Vineyard One, exchangeable $\mathrm{Mg} \%$ increased in the both compost areas by 3\% (till) and 6\% (no-till). Soil Mg in the cover crop areas decreased by $11 \%$ (till) and 5\% (no-till) (Figure 28). The control/till area soil decreased Mg by 3\%. There was no trend in Vineyard Two (Figure 29). Soils collected from the compost areas decreased $\mathrm{Mg} \%$ by $40 \%$ in the tilled area and increased by $36 \%$ in the no-till area. Soils collected from the cover crop areas decreased Mg\% by $56 \%$ in the tilled area and increased by $8 \%$ in the no-till area. Soil from the control/till area increased by $17 \%$.

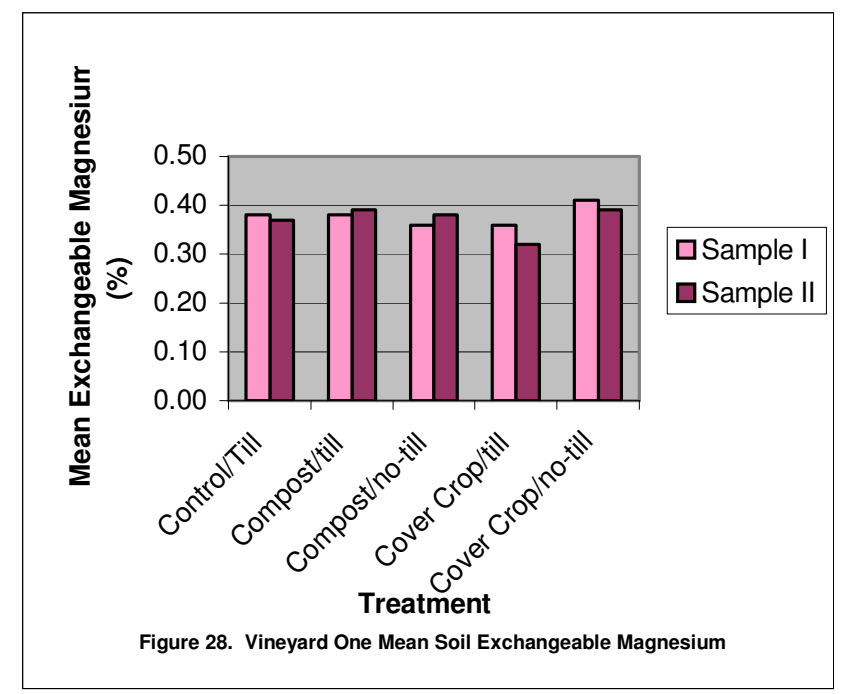




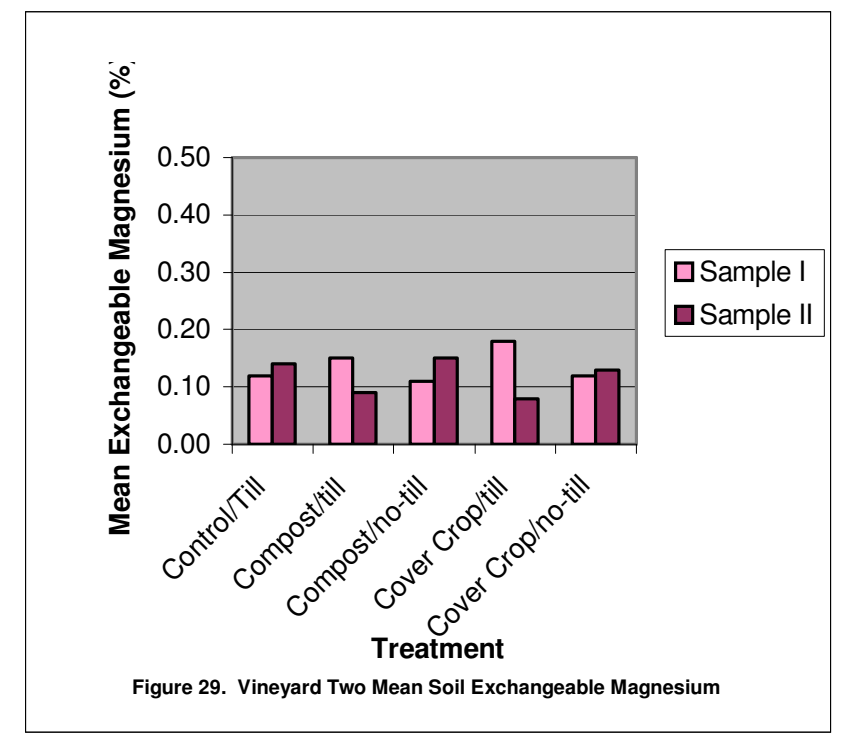

There was a significant difference $(P=<0.001)$ between Sub-blocks within blocks in terms of their mean soil CEC exchangeable Mg concentrations (Figure 30). That is, there was variability between vineyard blocks nested within a vineyard.

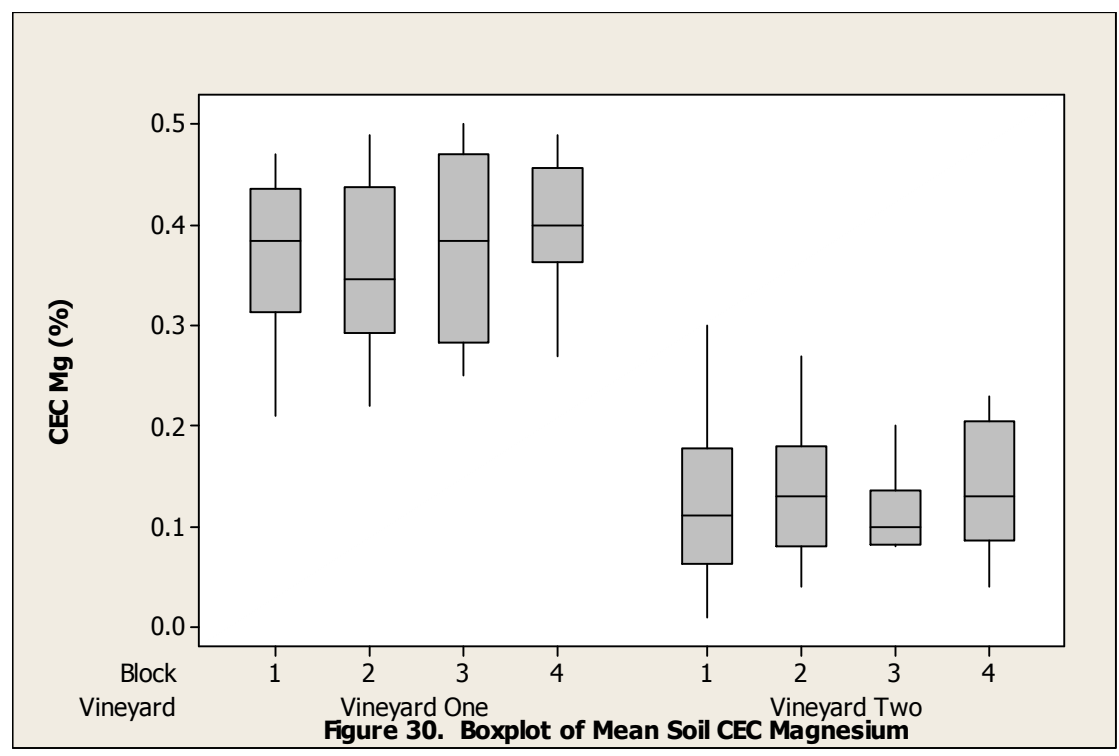

\section{Percentage of Exchangeable Potassium}

There was a statistically significant difference $(P<0.001)$ between vineyards in terms of their mean soil exchangeable $\mathrm{K}$ concentrations. Vineyard Two had slightly higher concentrations of exchangeable $\mathrm{K}$ than Vineyard One (Figure 31). Soils from Vineyard One contained $2 \% \mathrm{~K}$ prior to treatment and post treatment (decreased 0.001 ). 
Soils from Vineyard Two contained $3 \% \mathrm{~K}$ prior o treatment and following treatments (increased 0.0001).

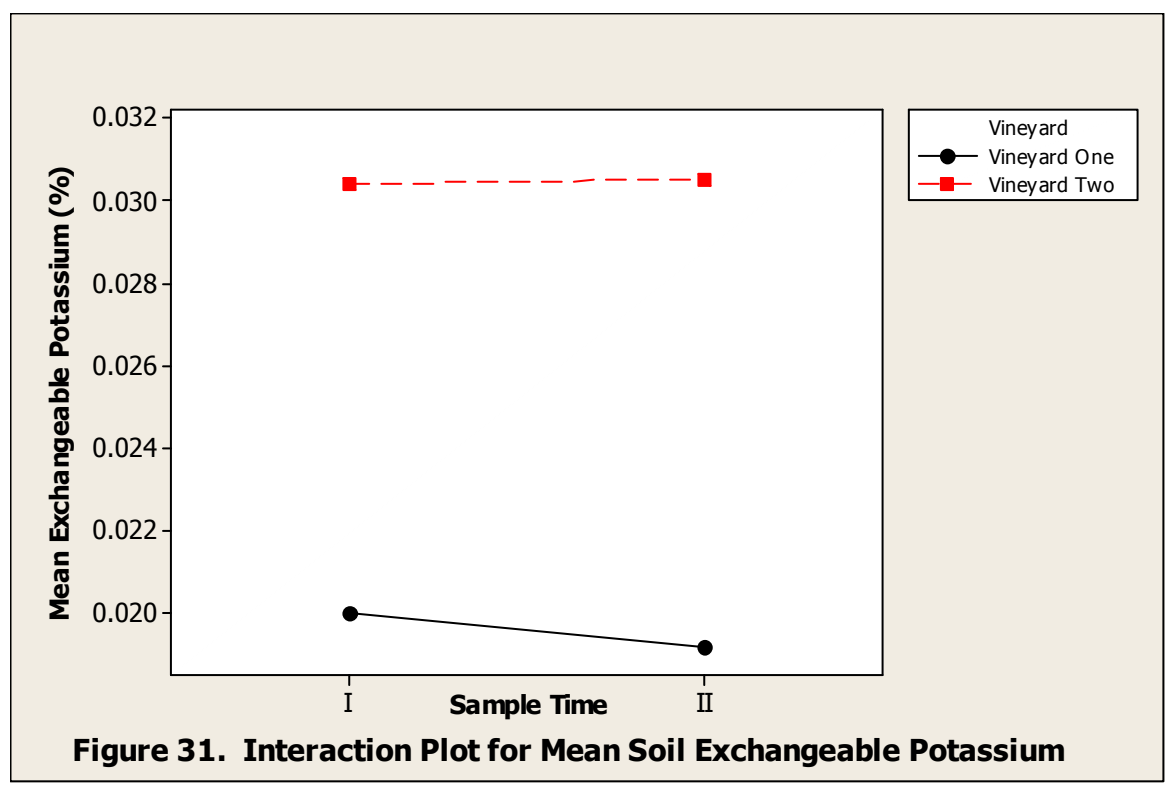

There was no significant difference between treatment areas and their affects on exchangeable $\mathrm{K} \%$ at both vineyards. At Vineyard One, there was no noticeable change in exchangeable $\mathrm{K} \%$ post treatment in any of the treatment areas (Figure 32). There was no trend in Vineyard Two (Figure 33). Soils collected from the compost areas increased exchangeable $\mathrm{K} \%$ by $50 \%$ in the tilled area and decreased $\mathrm{K} \%$ by $33 \%$ in the no-till area. Soils collected from the compost areas decreased $K \%$ by $25 \%$ in the tilled area and increased by $33 \%$ in the no-till area. Soil K\% did not change in the control/till area. 

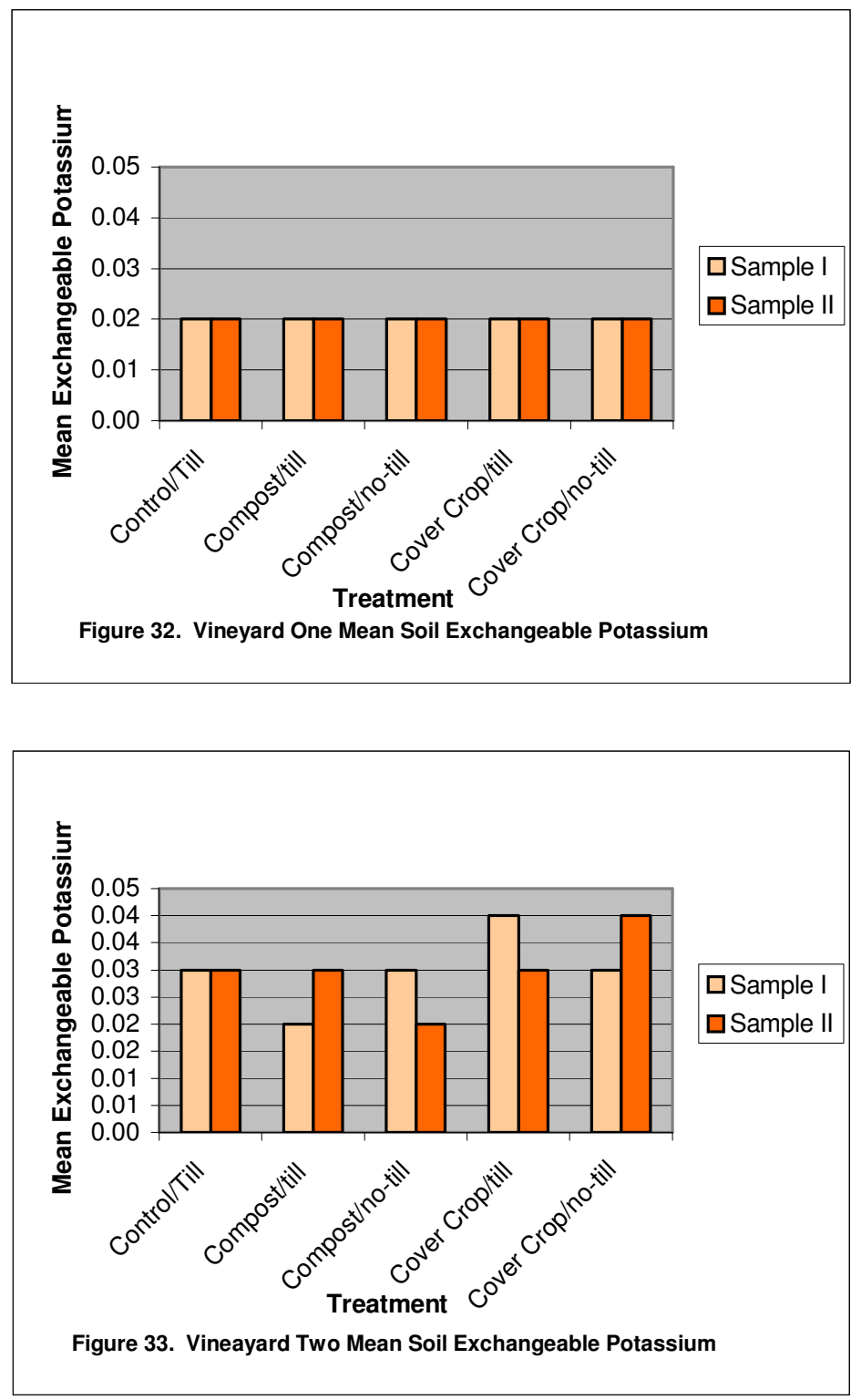

There was a significant difference $(P=<0.039)$ between Sub-blocks within blocks in terms of their mean soil CEC exchangeable $\mathrm{K}$ concentrations (Figure 34). This was more apparent in Vineyard 2. 


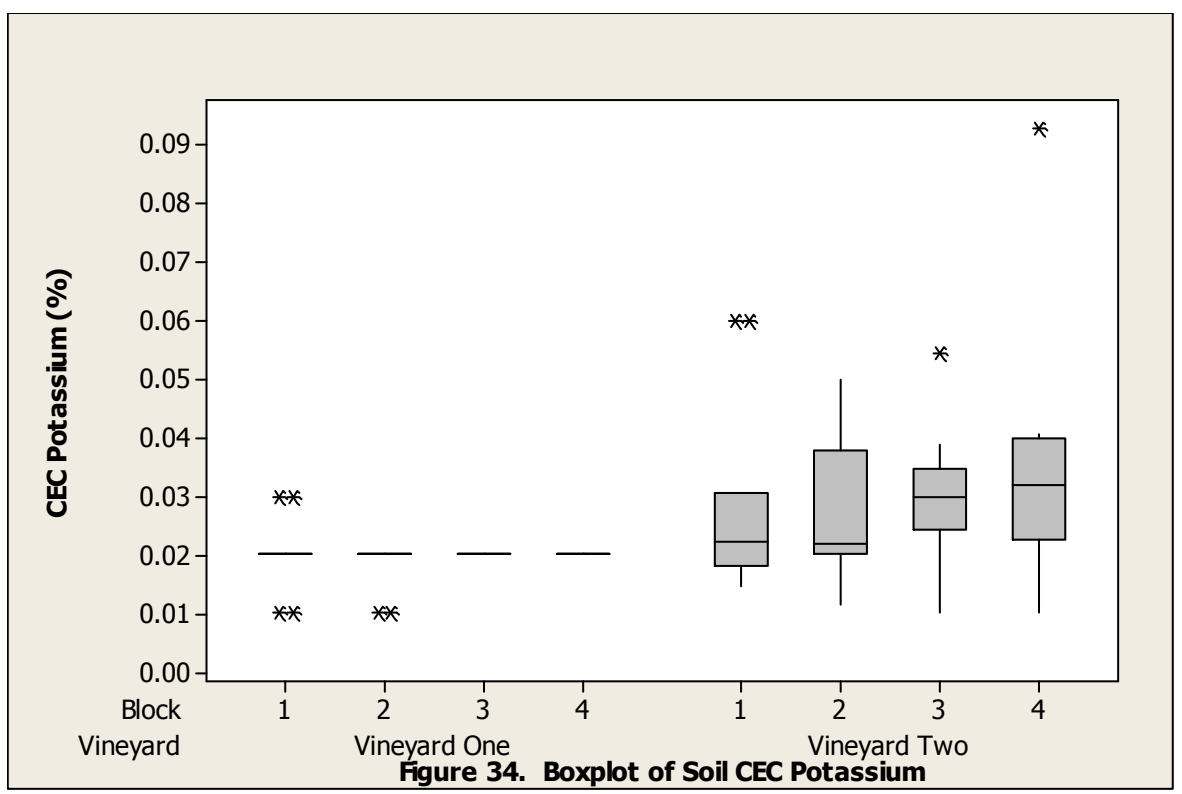

\section{Organic Carbon, Nitrogen and Organic Matter}

\section{Organic Carbon}

There was a slight difference between vineyards in terms of their mean soil organic C content. Vineyard One had slightly higher concentrations of organic C than Vineyard Two (Table 4, Table 5, \& Figure 35). Soils from Vineyard One contained, on average, $1.39 \% \mathrm{C}$ prior to treatment and following treatment contained $1.53 \% \mathrm{C}$. Soils from Vineyard Two contained $1.12 \% \mathrm{C}$ prior to treatment and $1.20 \% \mathrm{C}$ following treatments.

There was a significant effect $(P<0.001)$ from sampling time on organic $C$. Concentrations of soil $\mathrm{C}$ increased over time at both vineyards. At both vineyards, soil organic C increased following treatment. The largest increase was seen between sampling periods one and two (Figure 35). 


\begin{tabular}{|lrllllll|}
\hline Table 4. Vineyard One Organic Carbon, Nitrogen and Matter \\
\hline Treatment & \multicolumn{8}{c|}{$\begin{array}{c}\text { Sample } \\
\text { Organic } \\
\text { Date }\end{array}$} & $\begin{array}{c}\text { Carbon } \\
\text { (\%) }\end{array}$ & $\begin{array}{c}\text { Organic } \\
\text { (\%) }\end{array}$ & $\begin{array}{c}\text { Organic } \\
\text { (\%) }\end{array}$ & St.D & $\begin{array}{c}\text { Matter } \\
\text { (\%) }\end{array}$ & St.D \\
& & & & & & & \\
\hline Control/till & $12 / 16 / 07$ & $\mathbf{1 . 3 6}$ & 0.13 & $\mathbf{0 . 1 3}$ & 0.04 & $\mathbf{2 . 7 8}$ & 0.25 \\
& $05 / 19 / 08$ & $\mathbf{1 . 4 7}$ & 0.19 & $\mathbf{0 . 1 1}$ & 0.02 & $\mathbf{3 . 0 6}$ & 0.36 \\
& $08 / 07 / 08$ & $\mathbf{1 . 5 4}$ & 0.16 & $\mathbf{0 . 1 2}$ & 0.02 & - & - \\
Compost/till & $12 / 16 / 07$ & $\mathbf{1 . 3 3}$ & 0.22 & $\mathbf{0 . 1 9}$ & 0.05 & $\mathbf{2 . 6 6}$ & 0.47 \\
& $05 / 19 / 08$ & $\mathbf{1 . 7 3}$ & 0.29 & $\mathbf{0 . 1 3}$ & 0.04 & $\mathbf{4 . 1 2}$ & 0.39 \\
& $08 / 07 / 08$ & $\mathbf{1 . 4 6}$ & 0.24 & $\mathbf{0 . 1 1}$ & 0.04 & - & - \\
Compost/no-till & $12 / 16 / 07$ & $\mathbf{1 . 3 8}$ & 0.06 & $\mathbf{0 . 1 4}$ & 0.03 & $\mathbf{2 . 8 2}$ & 0.22 \\
& $05 / 19 / 08$ & $\mathbf{1 . 8 4}$ & 0.30 & $\mathbf{0 . 1 4}$ & 0.02 & $\mathbf{3 . 5 7}$ & 0.38 \\
& $08 / 07 / 08$ & $\mathbf{1 . 4 1}$ & 0.24 & $\mathbf{0 . 1 0}$ & 0.03 & - & - \\
Cover Crop/till & $12 / 16 / 07$ & $\mathbf{1 . 5 0}$ & 0.01 & $\mathbf{0 . 1 3}$ & 0.02 & $\mathbf{2 . 9 4}$ & 0.25 \\
& $05 / 19 / 08$ & $\mathbf{1 . 5 0}$ & 0.13 & $\mathbf{0 . 1 2}$ & 0.01 & $\mathbf{3 . 0 8}$ & 0.35 \\
& $08 / 07 / 08$ & $\mathbf{1 . 6 7}$ & 0.09 & $\mathbf{0 . 1 4}$ & 0.01 & - & - \\
Cover Crop/no-till12/16/07 & $\mathbf{1 . 4 2}$ & 0.11 & $\mathbf{0 . 1 5}$ & 0.03 & $\mathbf{2 . 9 6}$ & 0.34 \\
& $05 / 19 / 08$ & $\mathbf{1 . 6 2}$ & 0.32 & $\mathbf{0 . 1 2}$ & 0.02 & $\mathbf{3 . 4 7}$ & 0.77 \\
& $08 / 07 / 08$ & $\mathbf{1 . 6 0}$ & 0.26 & $\mathbf{0 . 1 3}$ & 0.03 & - & - \\
\hline
\end{tabular}

\begin{tabular}{|lcccccccc|}
\hline Table 5. Vineyard Two Soil Organic Carbon, Nitrogen and Matter \\
\hline Treatment & $\begin{array}{c}\text { Sample } \\
\text { Drganic } \\
\text { Date }\end{array}$ & $\begin{array}{c}\text { Organic } \\
\text { Carbon }\end{array}$ & $\begin{array}{c}\text { Organic } \\
\text { (\%) }\end{array}$ & $\begin{array}{c}\text { Nitrogen } \\
\text { (\%) }\end{array}$ & $\begin{array}{c}\text { Organic } \\
\text { Matter } \\
\text { (\%) }\end{array}$ & St.D \\
\hline Control/till & $12 / 15 / 07$ & $\mathbf{1 . 1 3}$ & 0.38 & $\mathbf{0 . 1 1}$ & 0.03 & $\mathbf{1 . 5 7}$ & 0.47 \\
& $06 / 12 / 08$ & $\mathbf{1 . 3 8}$ & 0.26 & $\mathbf{0 . 1 2}$ & 0.02 & $\mathbf{1 . 9 7}$ & 0.53 \\
& $08 / 07 / 08$ & $\mathbf{1 . 1 9}$ & 0.34 & $\mathbf{0 . 1 0}$ & 0.03 & - & - \\
Compost/till & $12 / 15 / 07$ & $\mathbf{1 . 1 1}$ & 0.41 & $\mathbf{0 . 1 0}$ & 0.03 & $\mathbf{1 . 2 8}$ & 0.22 \\
& $06 / 12 / 08$ & $\mathbf{1 . 4 9}$ & 0.19 & $\mathbf{0 . 1 4}$ & 0.01 & $\mathbf{1 . 9 3}$ & 0.21 \\
& $08 / 07 / 08$ & $\mathbf{1 . 2 1}$ & 0.15 & $\mathbf{0 . 1 0}$ & 0.02 & - & - \\
Compost/no-till & $12 / 15 / 07$ & $\mathbf{1 . 1 5}$ & 0.28 & $\mathbf{0 . 1 0}$ & 0.03 & $\mathbf{1 . 4 7}$ & 0.42 \\
& $06 / 12 / 08$ & $\mathbf{1 . 5 3}$ & 0.22 & $\mathbf{0 . 1 3}$ & 0.03 & $\mathbf{2 . 1 5}$ & 0.61 \\
& $08 / 07 / 08$ & $\mathbf{1 . 1 3}$ & 0.30 & $\mathbf{0 . 1 0}$ & 0.03 & - & - \\
Cover Crop/till & $12 / 15 / 07$ & $\mathbf{1 . 1 0}$ & 0.48 & $\mathbf{0 . 1 1}$ & 0.04 & $\mathbf{1 . 5 8}$ & 0.73 \\
& $06 / 12 / 08$ & $\mathbf{1 . 3 9}$ & 0.27 & $\mathbf{0 . 1 2}$ & 0.04 & $\mathbf{2 . 1 1}$ & 0.94 \\
& $08 / 07 / 08$ & $\mathbf{1 . 2 7}$ & 0.47 & $\mathbf{0 . 1 2}$ & 0.05 & - & - \\
Cover Crop/no-till12/15/07 & $\mathbf{1 . 1 2}$ & 0.24 & $\mathbf{0 . 1 0}$ & 0.02 & $\mathbf{1 . 5 3}$ & 0.34 \\
& $06 / 12 / 08$ & $\mathbf{1 . 4 1}$ & 0.32 & $\mathbf{0 . 1 4}$ & 0.04 & $\mathbf{2 . 3 0}$ & 0.71 \\
& $08 / 07 / 08$ & $\mathbf{1 . 2 6}$ & 0.40 & $\mathbf{0 . 1 1}$ & 0.04 & - & - \\
\hline
\end{tabular}




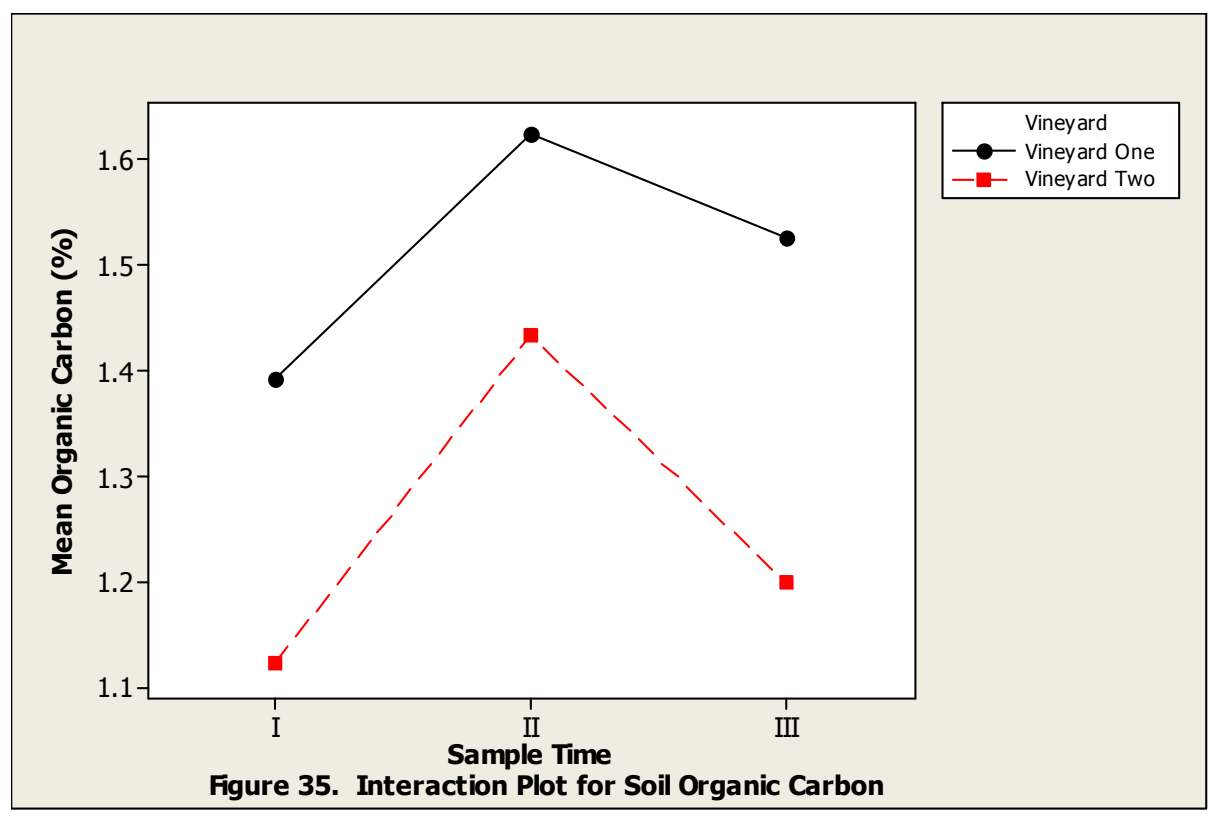

There was not a significant difference between treatments and their effects on soil organic C. At Vineyard One, soil C increased in all treatment areas (Figure 36). Post-treatment, the compost/till area soil $\mathrm{C}$ increased by $10 \%$ and the compost/no-till area average soil $\mathrm{C}$ increased by $2 \%$. In the cover crop areas the $\mathrm{C}$ increased by $11 \%$ (till) and $13 \%$ (no-till). The control/till area soil increased C by $13 \%$. At Vineyard Two, soil $\mathrm{C}$ increased in all areas except compost no-till and the control (Figure 37). Soils collected from the compost areas increased $9 \%$ (tilled) and decreased by $2 \%$ (no-till). Soils from the cover crop/till area increased by $15 \%$ and increased by $13 \%$ in the no-till area. Soil from the control/till area decreased by $5 \%$.

There was also a significant interaction $(P=0.009)$ between the effects of treatment/till and sample time on organic $C$, that is, treatment till effected organic $\mathrm{C}$ differently over time. The largest increase in $\mathrm{C}$ occurred between the first and second sampling periods, at both vineyards and in most treatment areas. At Vineyard One, the largest increase between sampling period I and II occurred in soils collected from the cover crop no-till areas whereas in Vineyard Two the largest increase was found in soil from the cover crop/till area and control. 

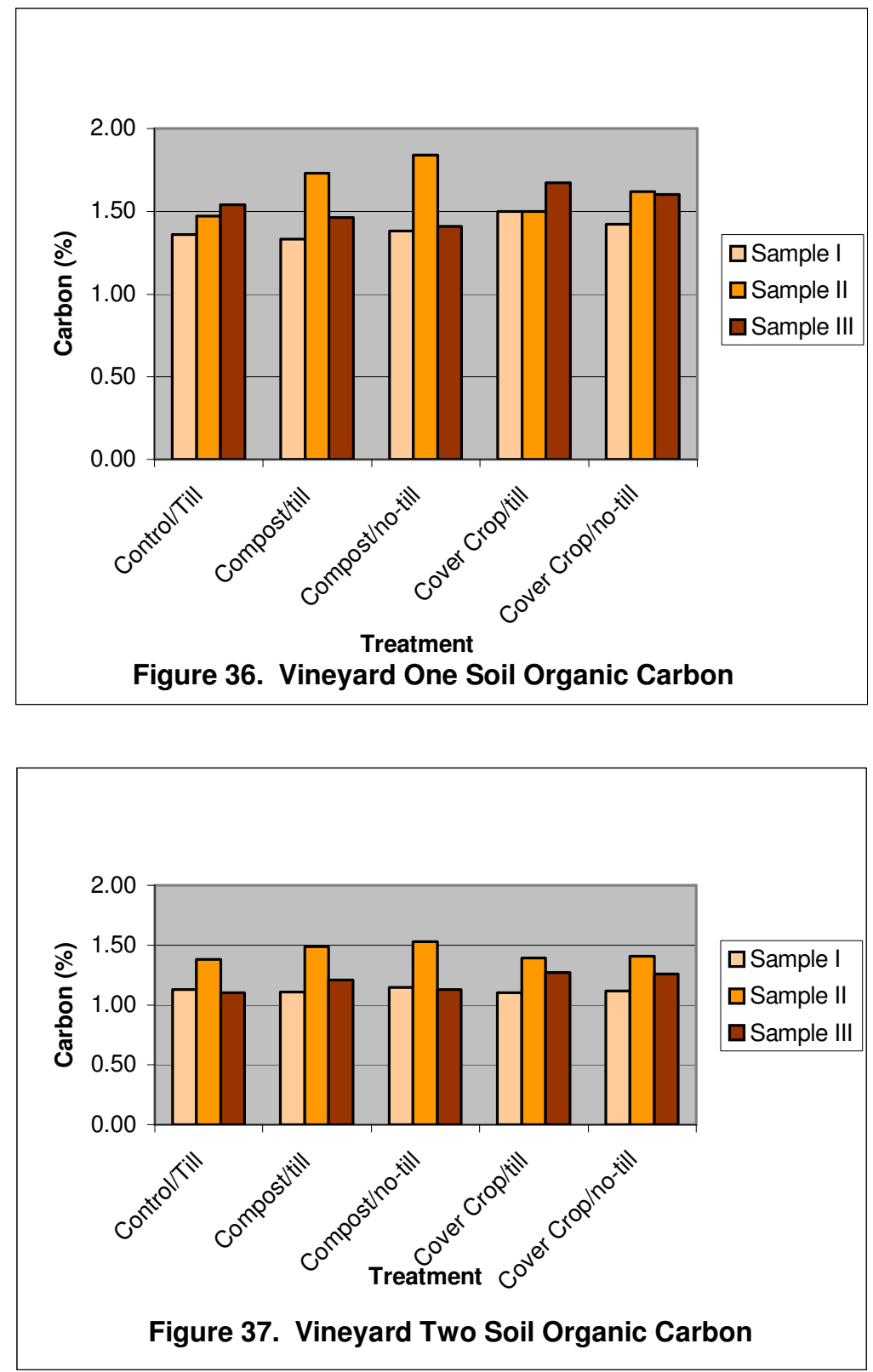

There was a statistically significant difference $(P=0.024)$ between blocks within vineyards in terms of their soil organic $\mathrm{C}$ percentages (Figure 38). That is, there was variability between the blocks nested within a vineyard. 


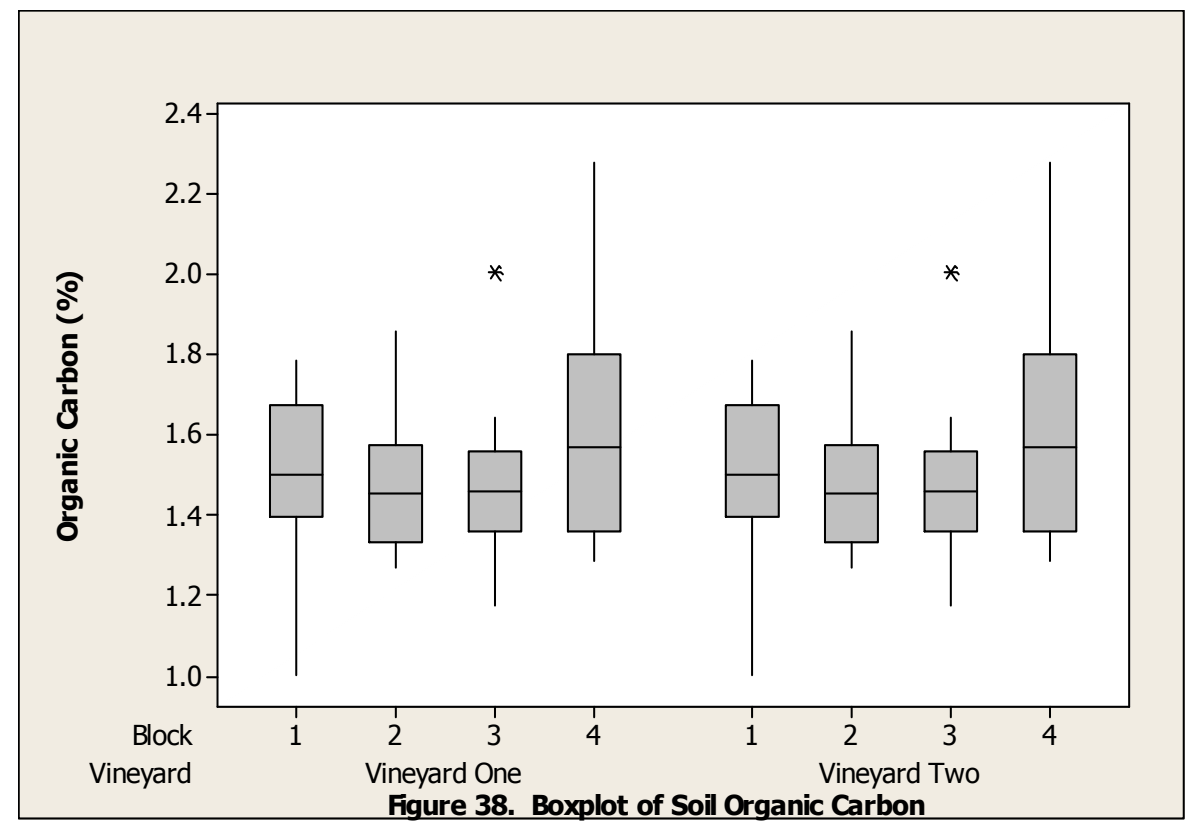

\section{Organic Nitrogen}

There was a slight difference between vineyards and their effects on organic N. Vineyard One had slightly higher concentrations of $\mathrm{N}$ than Vineyard Two (Figure 39). Soils from Vineyard One contained, on average, $0.14 \% \mathrm{~N}$ prior to treatment and following treatment contained $0.12 \% \mathrm{~N}$. Soils from Vineyard Two contained $0.11 \% \mathrm{~N}$ prior to treatment and $0.10 \% \mathrm{~N}$ following treatments.

There was a significant effect $(P<0.001)$ from sampling time on organic $N$. Concentrations of soil $\mathrm{N}$ decreased over time at both vineyards (Table 4 and Table 5, Figure 39). 


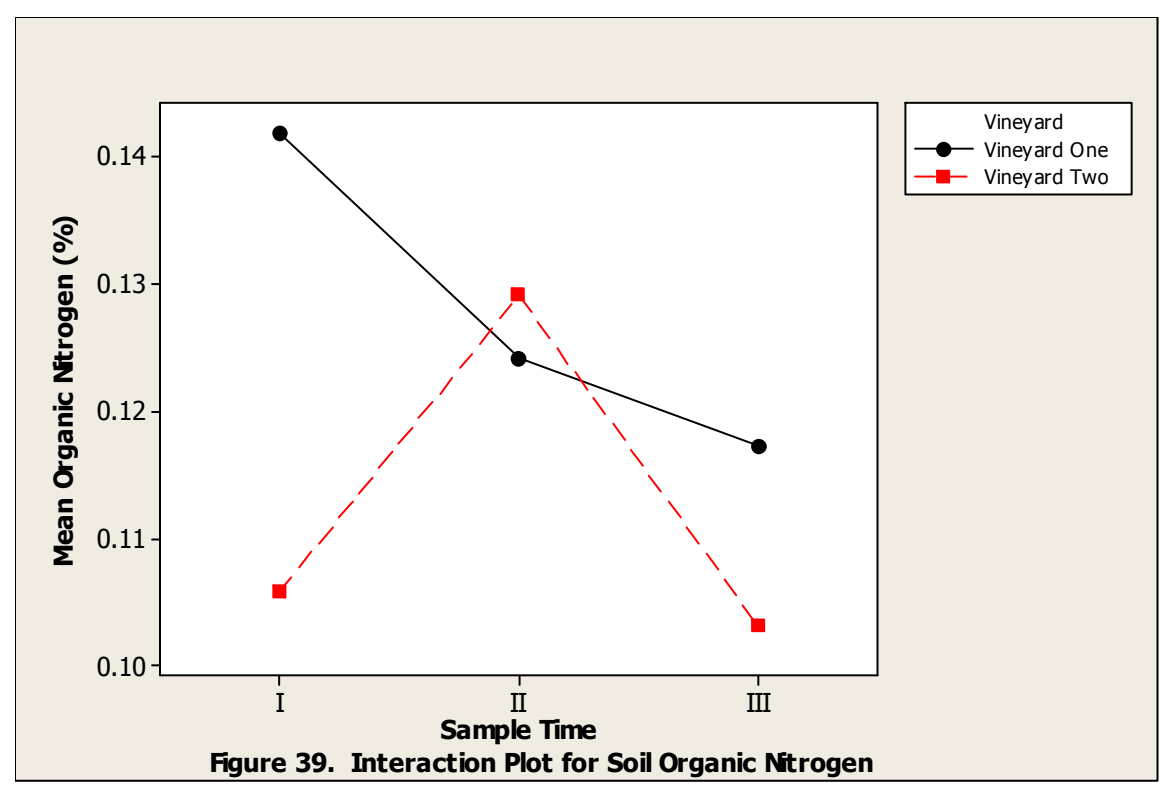

There was a significant difference $(P=0.027)$ between treatments and their effects on soil organic $\mathrm{N}$. At Vineyard One, soil $\mathrm{N}$ increased in all treatment areas except the cover crop till areas (Figure 40). Post-treatment, the compost/till area soil $\mathrm{N}$ decreased by $47 \%$ and the compost/no-till area average soil $\mathrm{N}$ decreased by $29 \%$. In the cover crop areas the $\mathrm{N}$ increased by $8 \%$ (till) and decreased by $13 \%$ (no-till). The control/till area soil decreased $\mathrm{N}$ by $8 \%$. At Vineyard Two, soil $\mathrm{N}$ increased in the cover crop areas (Figure 41). Soils collected from the compost areas (both) had no change in soil $\mathrm{N}$ post treatment. Soils from the cover crop/till area increased by $9 \%$ and increased by $10 \%$ in the no-till area. Soil from the control/till area decreased by $9 \%$.

There was significant interaction $(P=0.016)$ between the effects of treatment/till and sample time on organic N. That is, time, effected the way treatments impacted soil N. 

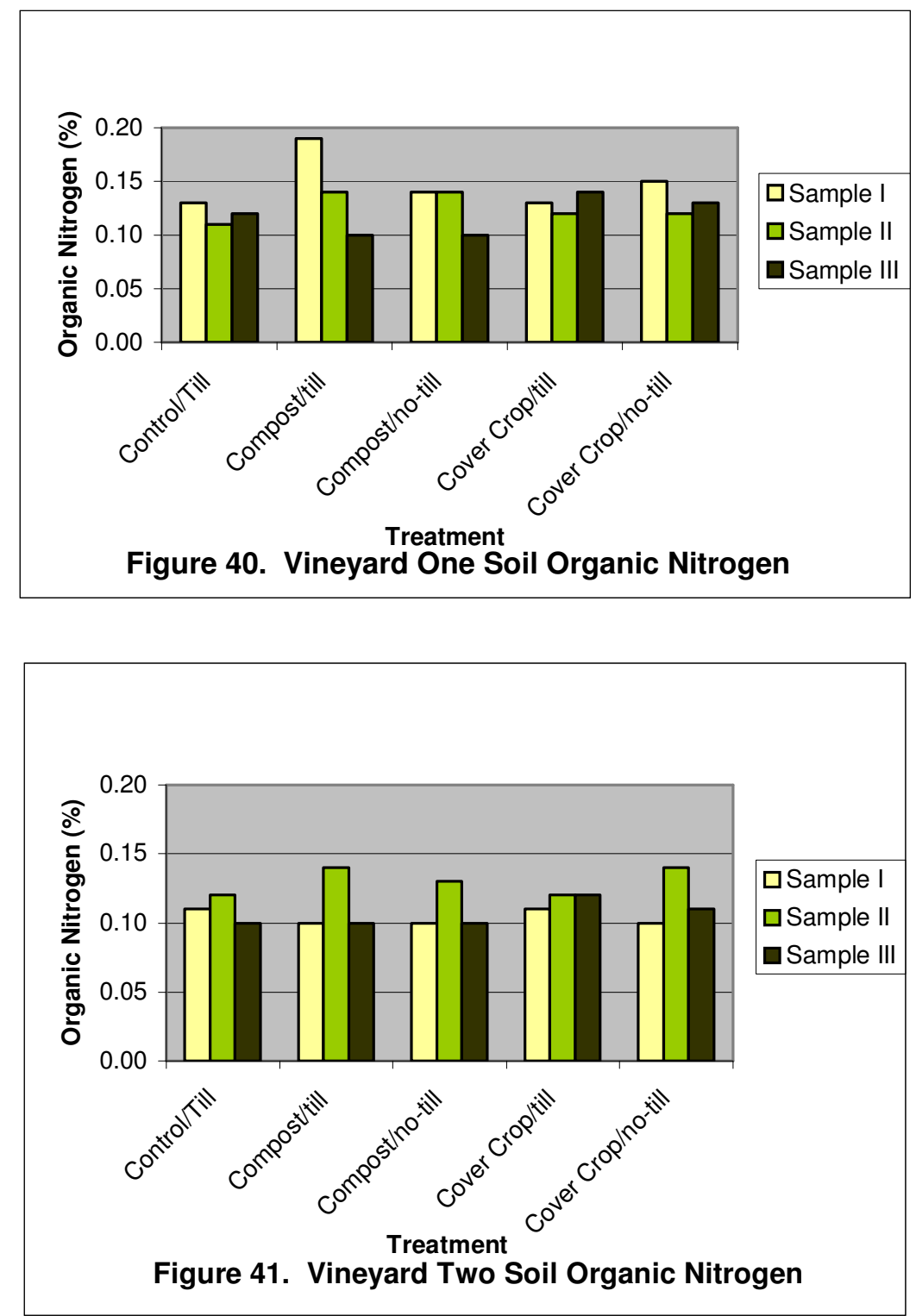

There was a significant difference $(P<0.001)$ between blocks within vineyards in terms of their mean soil organic $\mathrm{N}$ percentages (Figure 42). That is, there was variability between the blocks nested within a vineyard

There was also a significant difference, $(P=0.017)$, between Sub-blocks $(A$ and B) in terms of their mean soil organic N percentages (Figure 42) within blocks (I, II, III, and IV). Both vineyards had higher average $\mathrm{N}$ means in Sub-block $\mathrm{A}$ than in those collected from Sub-block B. 


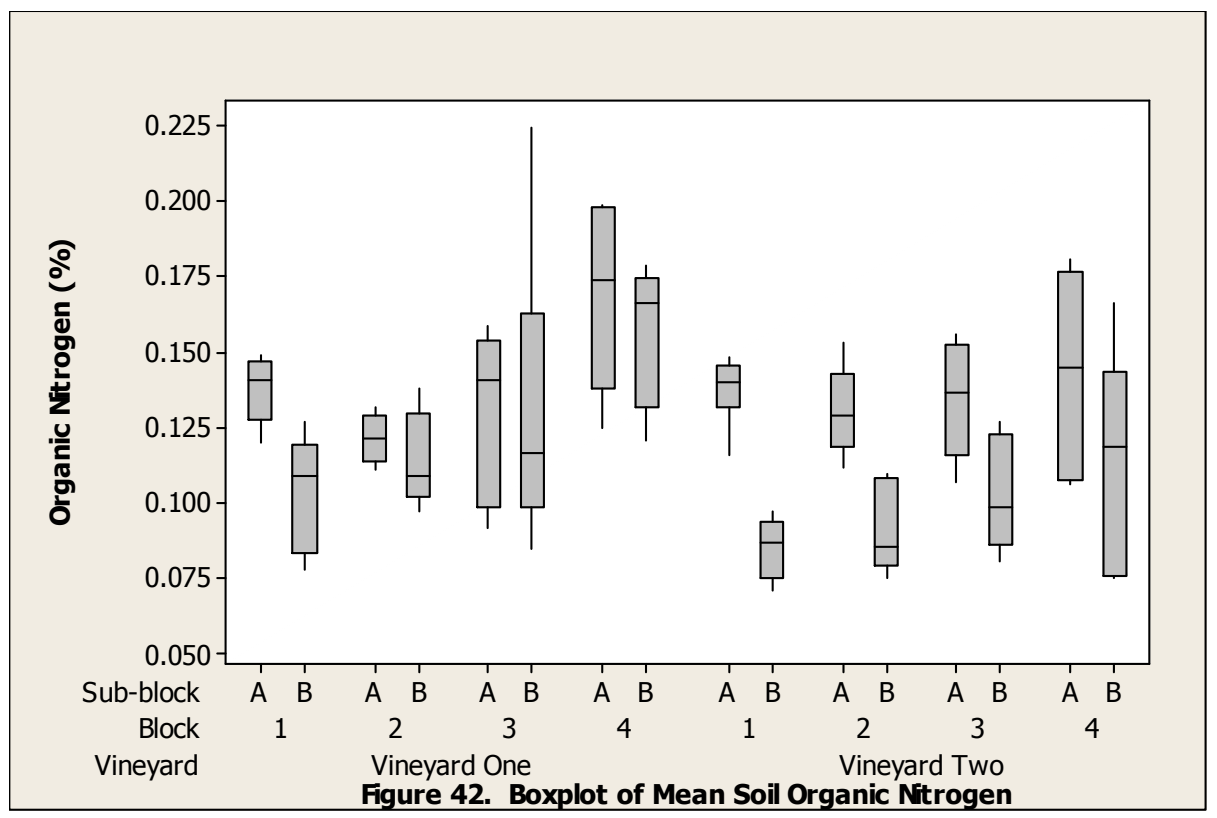

\section{Organic Matter}

Soil organic matter (OM) increased significantly in both vineyards during the course of the study and in all treatment areas. There was a significant difference $(\mathrm{P}<$ 0.001) between vineyards in terms of their mean soil OM percentages. Vineyard One had consistently higher percentages of soil OM than Vineyard Two (Table 4 \& 5, Figure 43). Prior to treatment soil samples from Vineyard One contained on average $2.84 \%$ OM and post-treatment contained $3.38 \%$. Vineyard Two contained on average $1.52 \%$ OM pre-treatment and $2.10 \%$ post treatment. 


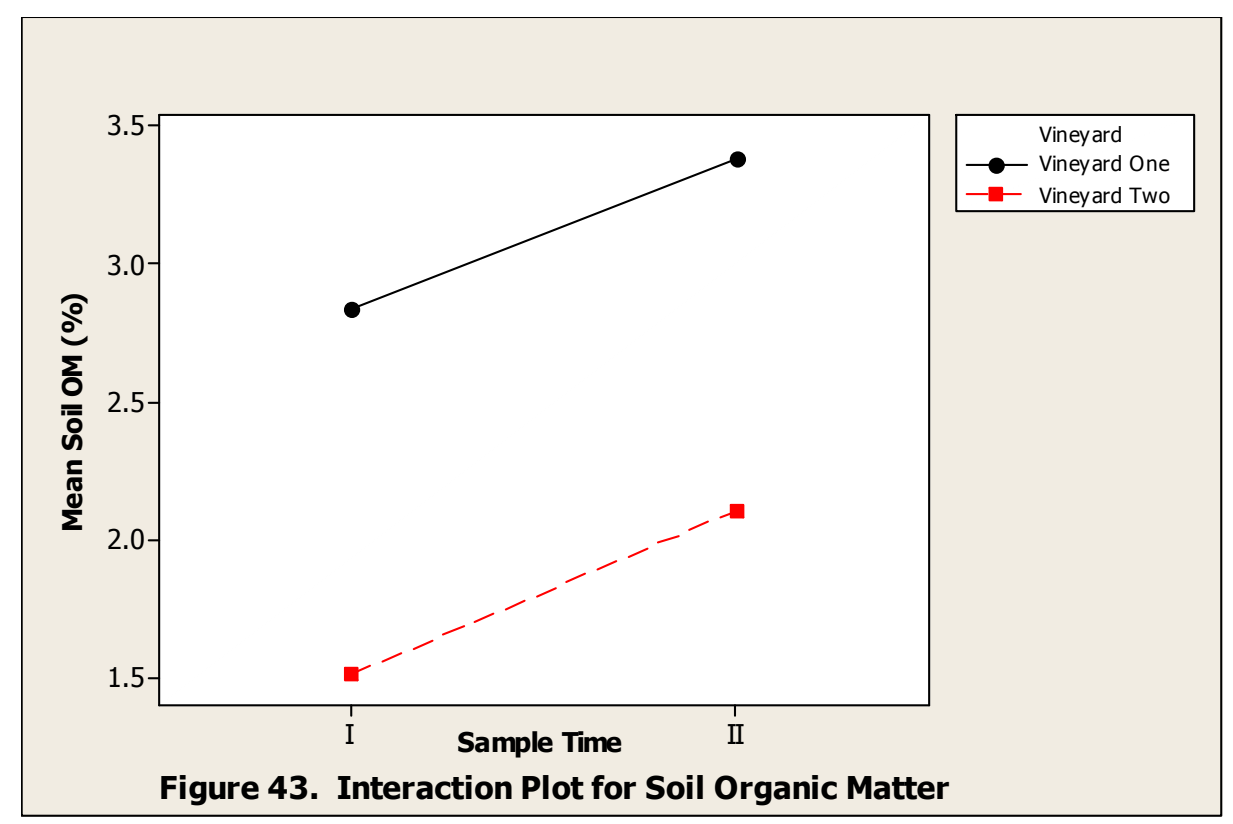

There was a significant affect from sampling time on OM $(P<0.001)$. That is, organic matter concentrations changed between the sampling times (pre and post treatment). Concentrations of soil OM increased over time at both vineyards (Table 4, Table 5 and Figures 44 and 45). At Vineyard One, soil OM increased more in the soils collected from the compost areas. Soil from the compost/till area saw an increase of $55 \%$ while soil from the compost/no-till saw an increase of $27 \%$. Soils from the cover crop/till area increased by $5 \%$ and soils from the cover crop/no-till increased by $17 \%$. The control/till area had an increase of $10 \%$. At Vineyard Two, soil OM increased slightly more in soils collected from the compost areas. The compost/till area soils had an average increase in $\mathrm{OM}$ of $51 \%$ while the cover/crop no-till soils had an average increase of $46 \%$. Soils from the cover crop/till area increased OM by $34 \%$ and those from the cover crop/no-till increased OM by $50 \%$. Soils from the control/till area had an increase in $\mathrm{OM}$ of $25 \%$. 

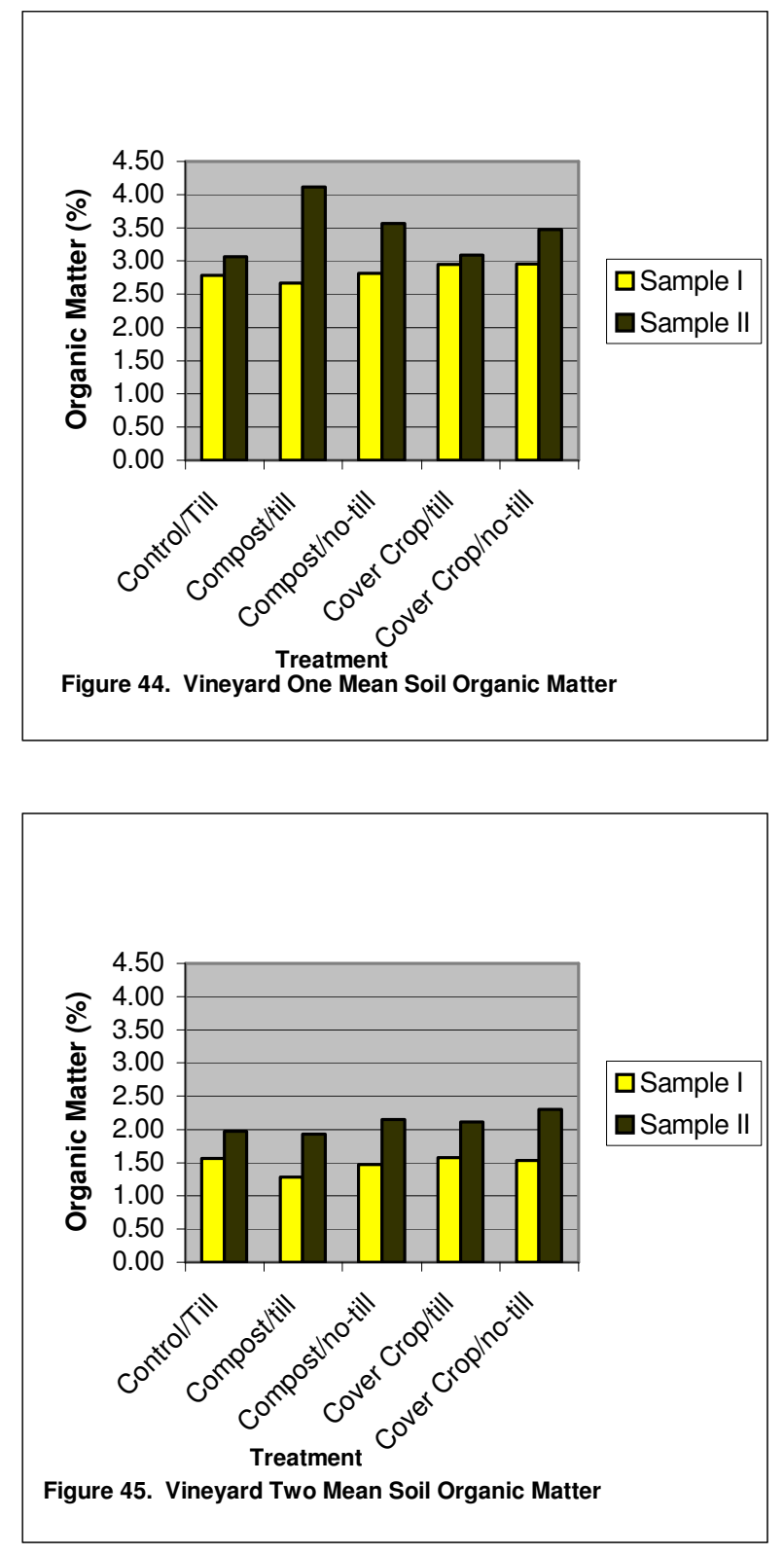

There was also a significant difference, $(P<0.001)$, between Sub-blocks $(A$ and B) within blocks and their mean soil OM percentage (Figure 46). The P value suggests there is a noticeable difference between $A$ and $B$ at least one of the vineyards. In Vineyard One, soil OM means were slightly higher in those collected from Sub-block A than in Sub-block B. In Vineyard Two, soils had higher average organic matter means in Sub-block A than in those collected from Sub-block B. 


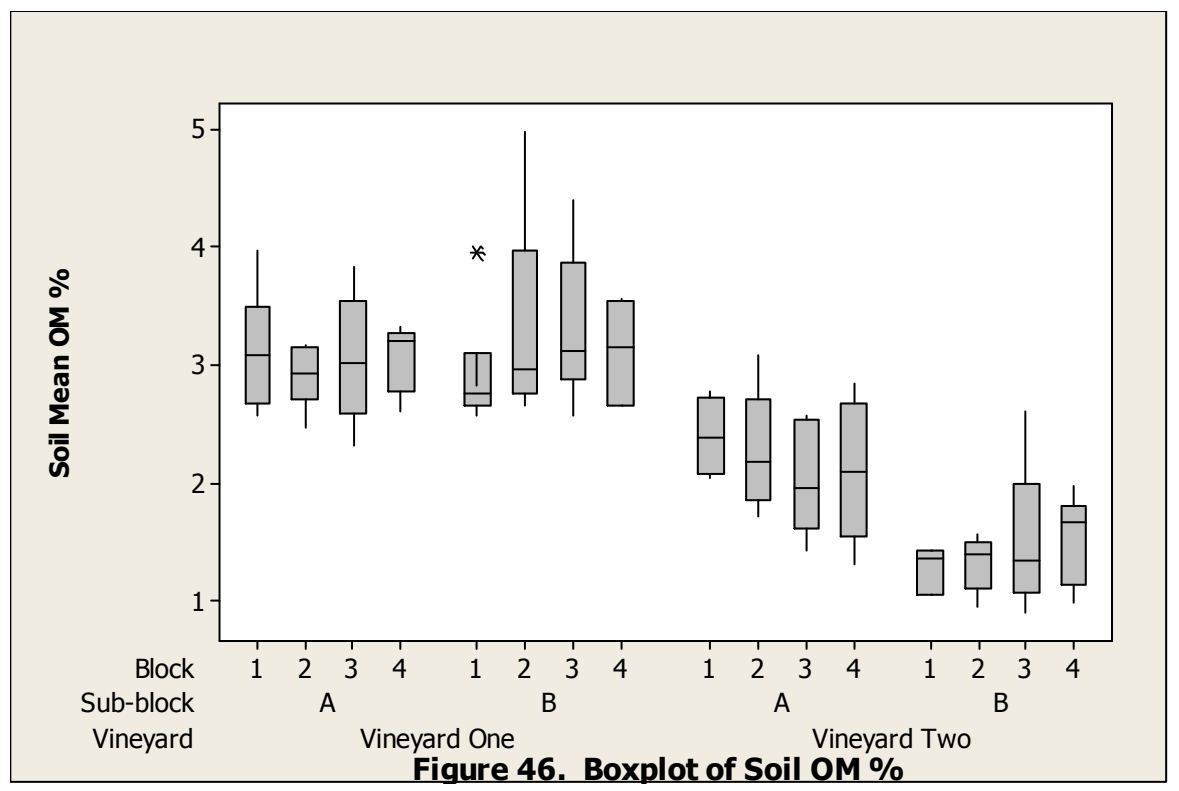

\section{Select Soil Ratios}

\section{Exchangeable Ca/Ma Ratios}

There was a significant difference $(P=0.007)$ between vineyards in terms of their mean exchangeable Ca/Mg ratios. Vineyard Two had consistently higher exchangeable $\mathrm{Ca} / \mathrm{Mg}$ ratios than Vineyard One (Table $6 \& 7$, Figure 47). Prior to treatment soil from Vineyard One had on average a 1.70 exchangeable $\mathrm{Ca} / \mathrm{Mg}$ ratio and post treatment 1.78 exchangeable $\mathrm{Ca} / \mathrm{Mg}$ ratio. Vineyard Two contained on average an exchangeable $\mathrm{Ca} / \mathrm{Mg}$ ratio of 11.75 pre-treatment and an exchangeable $\mathrm{Ca} / \mathrm{Mg}$ ratio of 7.21 posttreatment. 


\begin{tabular}{|c|c|c|c|c|c|}
\hline Treatment & Sample Date & $\begin{array}{c}\text { CEC Exch } \\
\text { Ca/Mg } \\
\text { Ratio }\end{array}$ & St.D & $\begin{array}{c}\text { Org C/N } \\
\text { Ratio }\end{array}$ & St.D \\
\hline \multirow[t]{3}{*}{ Control/till ${ }^{9}$} & $12 / 16 / 07$ & 1.77 & 0.79 & 10.98 & 2.60 \\
\hline & 05/19/08 & 1.84 & 0.88 & 13.06 & 1.62 \\
\hline & 08/07/08 & - & - & 13.31 & 1.46 \\
\hline \multirow[t]{3}{*}{ Compost/till } & $12 / 16 / 07$ & 1.78 & 0.10 & 7.29 & 0.93 \\
\hline & 05/19/08 & 1.62 & 0.65 & 13.34 & 1.03 \\
\hline & 08/07/08 & - & - & 13.38 & 2.29 \\
\hline \multirow[t]{3}{*}{ Compost/no-till } & $12 / 16 / 07$ & 1.77 & 0.39 & 10.32 & 2.45 \\
\hline & 05/19/08 & 1.66 & 0.53 & 12.92 & 1.33 \\
\hline & 08/07/08 & - & - & 13.73 & 1.36 \\
\hline \multirow[t]{3}{*}{ Cover Crop/till } & $12 / 16 / 07$ & 1.79 & 0.40 & 11.72 & 1.68 \\
\hline & 05/19/08 & 2.46 & 1.62 & 13.00 & 0.37 \\
\hline & 08/07/08 & - & - & 12.28 & 0.00 \\
\hline \multirow[t]{3}{*}{ Cover Crop/no-till } & $12 / 16 / 07$ & 1.48 & 0.47 & 10.10 & 1.79 \\
\hline & $05 / 19 / 08$ & 1.65 & 0.77 & 13.55 & 1.09 \\
\hline & 08/07/08 & - & - & 13.09 & 2.04 \\
\hline
\end{tabular}

\begin{tabular}{|c|c|c|c|c|c|}
\hline Treatment & Sample Date & $\begin{array}{l}\text { CEC Exch } \\
\text { Ca/Mg Ratio }\end{array}$ & St.D & $\begin{array}{c}\text { Org C/N } \\
\text { Ratio }\end{array}$ & St.D \\
\hline \multirow[t]{3}{*}{ Control/till ${ }^{9}$} & $12 / 16 / 07$ & 8.74 & 5.78 & 10.34 & 0.63 \\
\hline & 05/19/08 & 5.99 & 2.22 & 11.27 & 1.26 \\
\hline & 08/07/08 & - & - & 11.91 & 1.10 \\
\hline \multirow[t]{3}{*}{ Compost/till } & $12 / 16 / 07$ & 6.04 & 4.07 & 10.60 & 0.62 \\
\hline & 05/19/08 & 8.63 & 1.11 & 10.89 & 0.33 \\
\hline & 08/07/08 & - & - & 12.16 & 1.02 \\
\hline \multirow[t]{3}{*}{ Compost/no-till } & $12 / 16 / 07$ & 24.10 & 37.5 & 11.07 & 1.04 \\
\hline & 05/19/08 & 6.27 & 3.51 & 12.26 & 1.29 \\
\hline & 08/07/08 & - & - & 11.76 & 0.77 \\
\hline \multirow[t]{3}{*}{ Cover Crop/till } & $12 / 16 / 07$ & 8.62 & 9.02 & 9.72 & 0.63 \\
\hline & $05 / 19 / 08$ & 11.63 & 0.72 & 11.94 & 1.40 \\
\hline & 08/07/08 & - & - & 11.03 & 0.96 \\
\hline \multirow[t]{3}{*}{ Cover Crop/no-till } & $12 / 16 / 07$ & 6.93 & 2.37 & 10.63 & 0.52 \\
\hline & $05 / 19 / 08$ & 7.49 & 3.59 & 10.30 & 1.86 \\
\hline & 08/07/08 & - & - & 11.80 & 1.12 \\
\hline
\end{tabular}



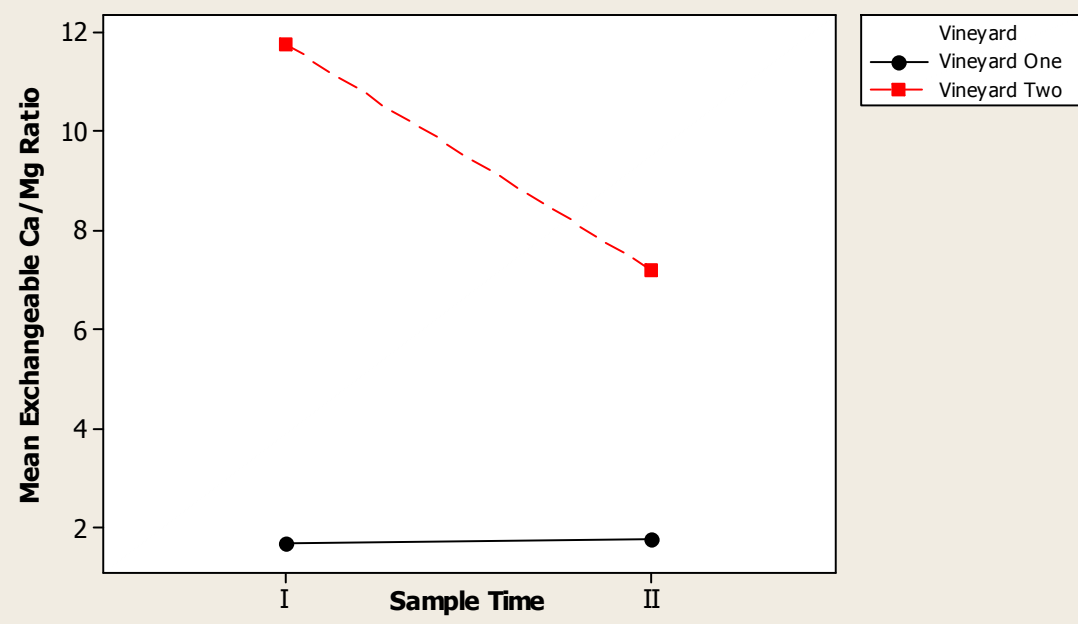

Figure 47. Interaction Plot for Mean Soil Exchangeable CaMg Ratios

There was no significant difference between treatment areas and their effects on exchangeable $\mathrm{Ca} / \mathrm{Mg}$ ratios at both vineyards. At Vineyard One, exchangeable $\mathrm{Ca} / \mathrm{Mg}$ ratios decreased in both compost areas by $9 \%$ (till) and 6\% (no-till). Exchangeable $\mathrm{Ca} / \mathrm{Mg}$ ratios in the cover crop areas increased by $37 \%$ (till) and 11\% (no-till) (Figure 48). The control/till area exchangeable $\mathrm{Ca} / \mathrm{Mg}$ ratio increased by $4 \%$. There was no trend in Vineyard Two (Figure 49). Soils collected from the compost areas increased exchangeable $\mathrm{Ca} / \mathrm{Mg}$ ratios by $43 \%$ in the tilled area and decreased by $74 \%$ in the no-till area. Soils collected from the cover crop areas increased exchangeable $\mathrm{Ca} / \mathrm{Mg}$ ratios by $35 \%$ in the tilled area and increased by $8 \%$ in the no-till area. Soil from the control/till area decreased exchangeable $\mathrm{Ca} / \mathrm{Mg}$ ratios by $31 \%$. 

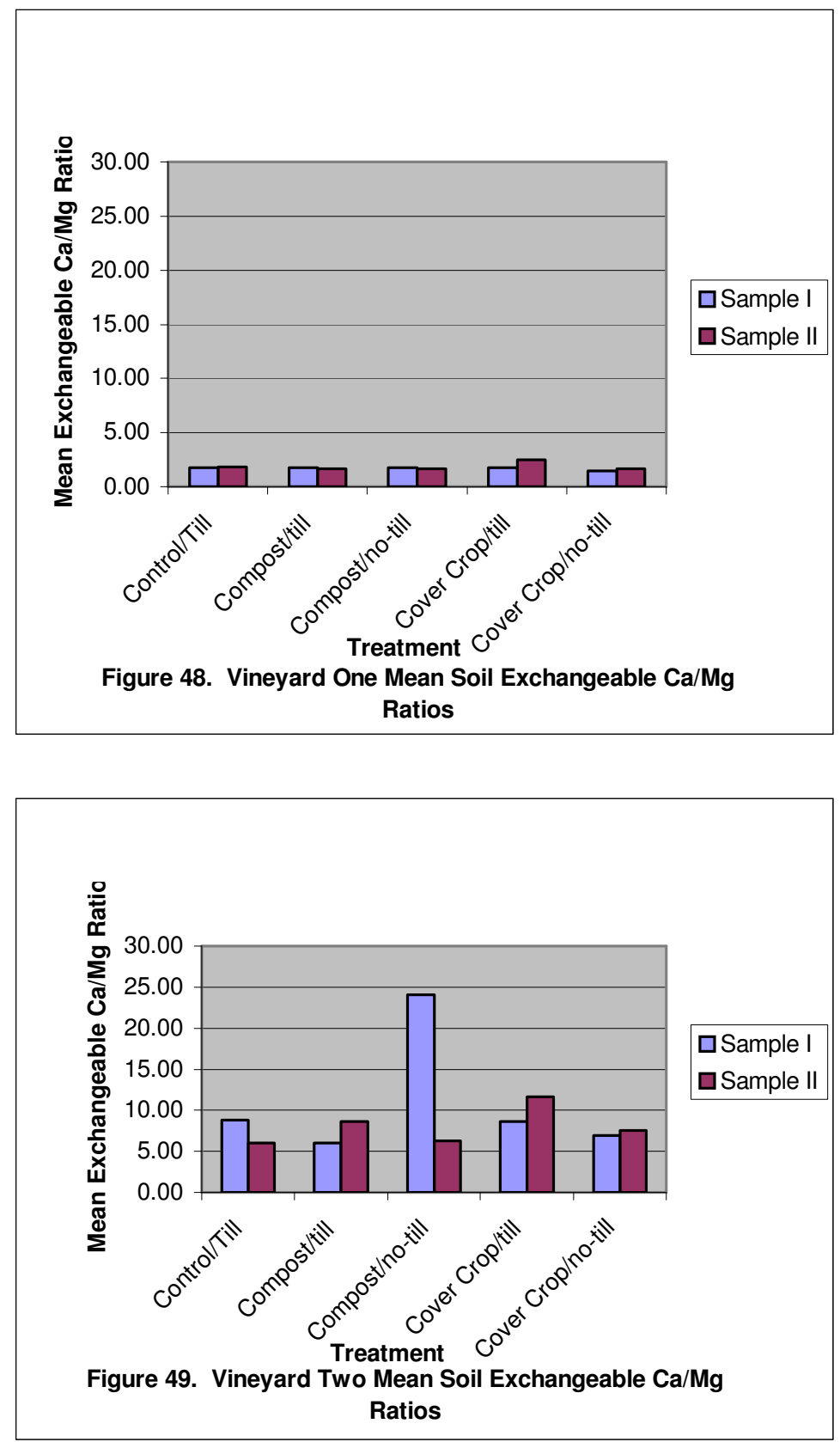

Soil pH did not significantly affect exchangeable $\mathrm{Ca} / \mathrm{Mg}$ ratios (Figure 50 ). 


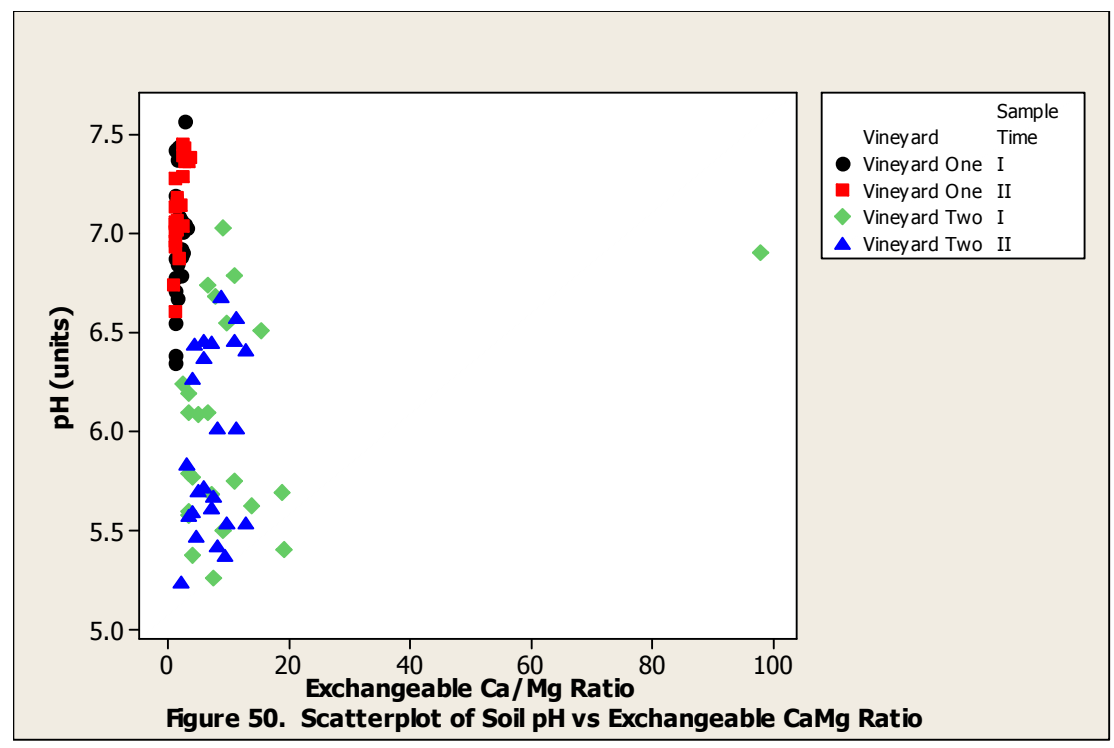

\section{C/N Ratios}

Soil $\mathrm{C} / \mathrm{N}$ ratios increased in both vineyards during the course of the study and in all treatment areas. There was a significant difference $(P=0.001)$ between vineyards in terms of their mean $\mathrm{C} / \mathrm{N}$ ratios (Figure 51). Soils from Vineyard One consistently had higher $\mathrm{C} / \mathrm{N}$ ratios than from soils in Vineyard Two. Soils from Vineyard One had, on average, a $\mathrm{C} / \mathrm{N}$ ratio of 10.34 prior to treatment and following treatment (August) a $\mathrm{C} / \mathrm{N}$ ratio of 13.28. Soils from Vineyard Two had, on average, had a $\mathrm{C} / \mathrm{N}$ ratio of 10.56 prior to treatment and following treatment (August) a $\mathrm{C} / \mathrm{N}$ ratio of 11.80 .

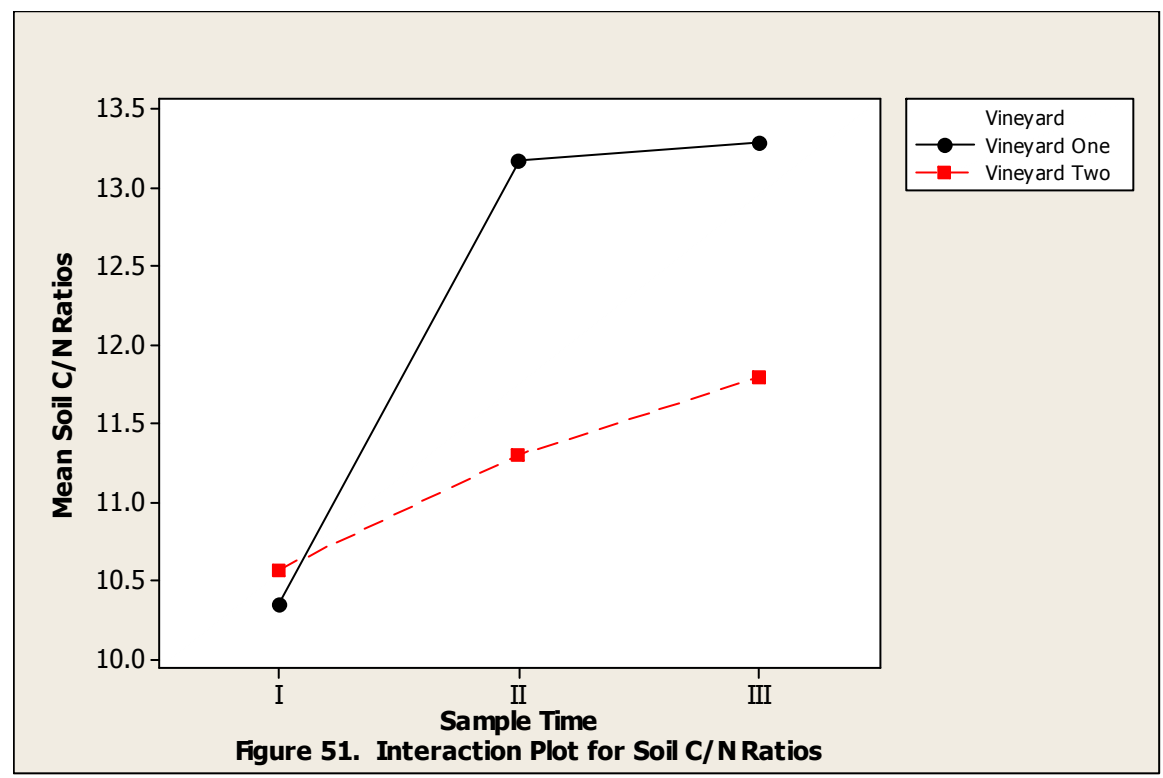


There was a significant effect $(P<0.001)$ from sampling time on $C / N$ ratios (above Figure 51). Concentrations of soil $\mathrm{C} / \mathrm{N}$ ratios increased over time at both vineyards (Table 5 and Table 6). At Vineyard One, soil $\mathrm{C} / \mathrm{N}$ ratios increased more in the soils collected from the compost areas, both tilled (84\%) and no-till (33\%), than those from the cover crop areas (tilled-5\%, no-till- 30\%) or control/till (21\%) (Figure 52). At Vineyard Two, soil $\mathrm{C} / \mathrm{N}$ ratios increased in all areas with no general trend (Figure 53). Soils collected from the compost areas increased 15\% (tilled) and 6\% (no-till). Soils from the cover crop areas increased by $21 \%$ (till) and $11 \%$ (no-till). Soil from the control/till area increased by $15 \%$.

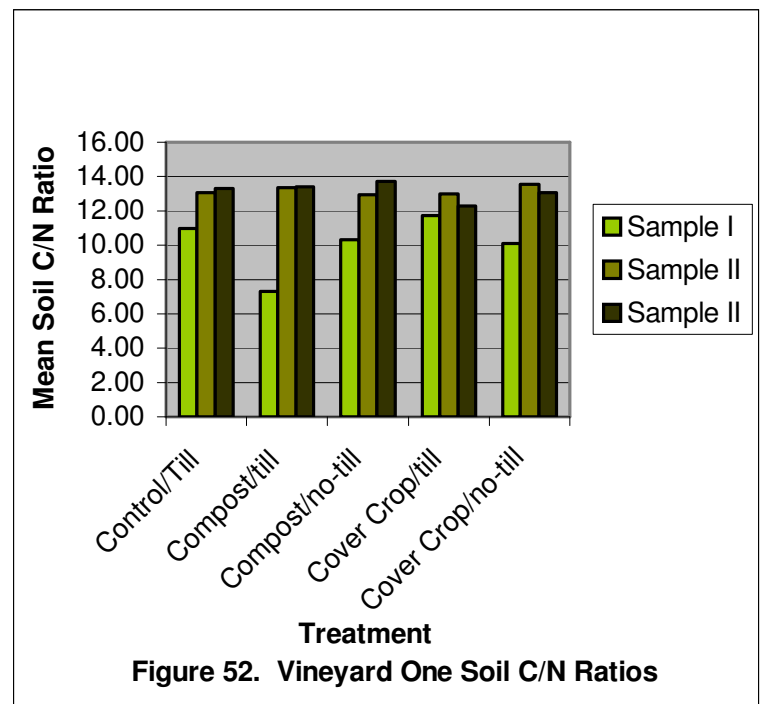




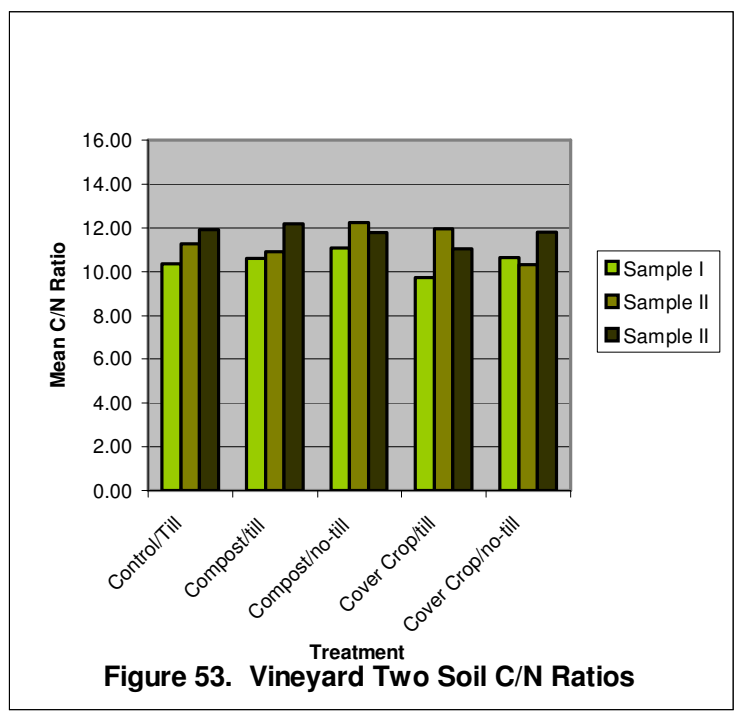

There was also a significant difference, $(P=0.041)$, between the effects of Subblocks ( $\mathrm{A}$ and $\mathrm{B}$ ) within blocks in terms of their soil $\mathrm{C} / \mathrm{N}$ ratios (Figure 54 ). In both vineyards, most soils had higher average $\mathrm{C} / \mathrm{N}$ ratio means in Sub-block $\mathrm{A}$ than in those collected from Sub-block B.

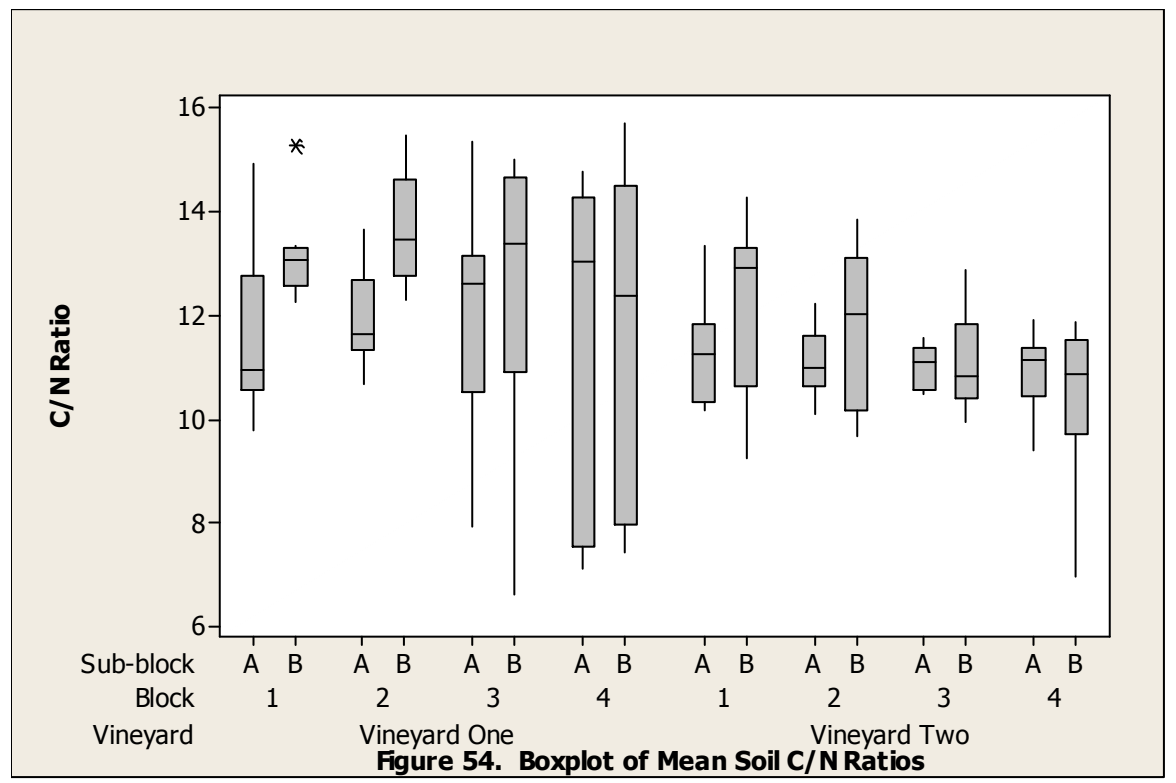

There was significant interaction $(P=0.001)$ between the effects of vineyard and sample time on $\mathrm{C} / \mathrm{N}$ ratios. That is, over time, the treatments had different impacts on soil $\mathrm{C} / \mathrm{N}$ ratios. The largest increase in $\mathrm{C} / \mathrm{N}$ ratios occurred between the first and second sampling periods, at both vineyards and in most treatment areas (Figure 55 and Figure 
56). At Vineyard One, the largest increase between sampling period I and II occurred in soils collected from the compost till areas whereas in Vineyard Two the largest increase was found in soil from the cover crop/till areas.
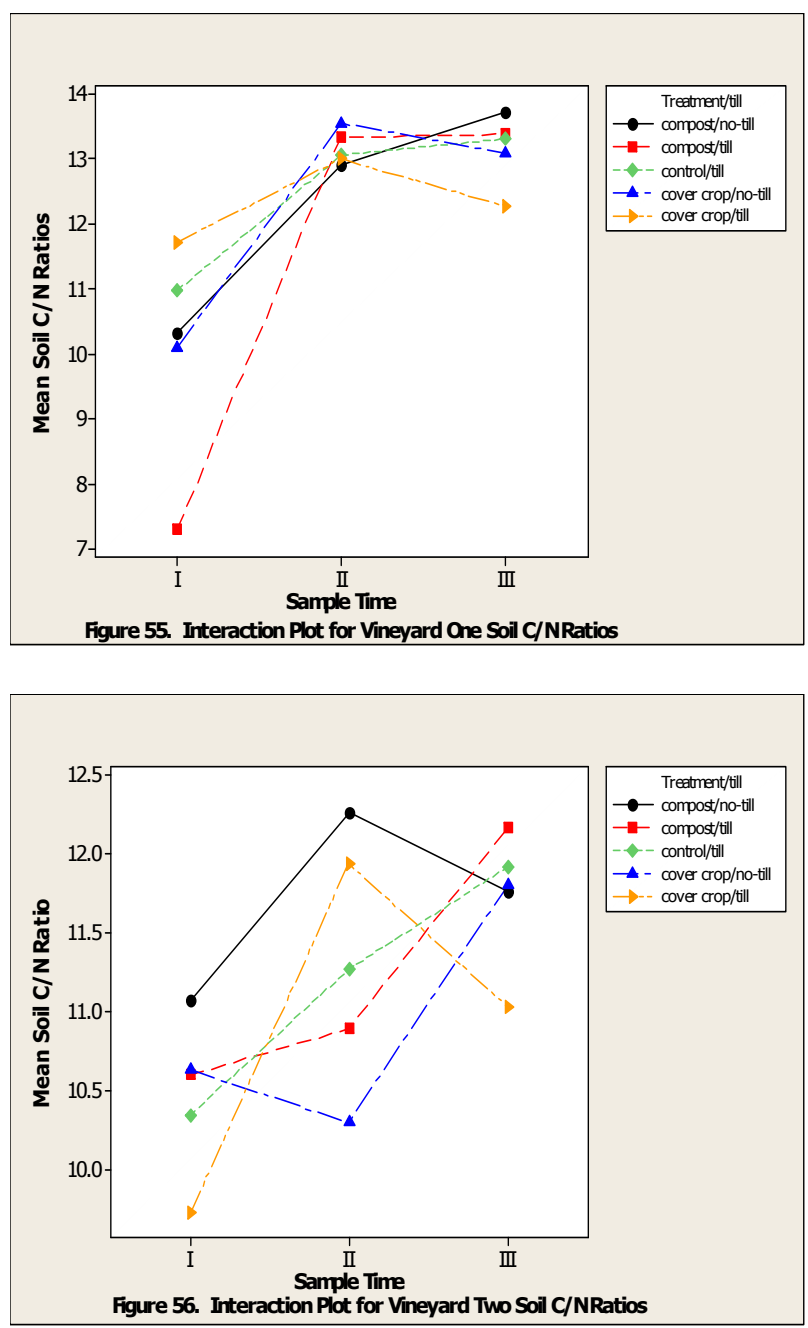


\section{DISCUSSION}

\section{SIGNIFICANT DIFFERENCE BETWEEN VINEYARDS AND THEIR MEAN NUTRIENT AND EXCHANGEABLE CATION CONCENTRATIONS}

The significant difference found between vineyards and their mean nutrient and exchangeable cation concentrations can be attributed to the differences in soil types at the two vineyards, as other factors (air temperature, precipitation, slope, orientation, etc.) were very similar.

\section{NO STATISTICAL SIGNIFICANT EFFECT FROM DIFFERENT TREATMENTS ON SOIL NUTRIENTS, EXCHANGEABLE CATIONS, AND RATIOS}

The lack of significant difference found between treatments and their effects on soil nutrients, exchangeable cations (except exchangeable $\mathrm{K}$ [not CEC\%], OM, and organic $\mathrm{N}$ ) was not entirely expected because other researchers have found significant effects from cover crops and compost on soil fertility. However, the results from this project were consistent with some (Smith et al., [2008], Vavoulidou et al., [2006], and Morlat \& Jacquet [2003]) who found very little/marginal effect from cover crop and or compost on soil nutrients (excluding OM). In addition, the research (that found significant effects from cover crops and compost on soil nutrients) was conducted over a several year period. One study, conducted at the Rodale Institute, spanned a 21-year period [Hepperly et al., 2008]). This project was conducted over a one-year period.

\section{TREATMENTS EFFECTED SOIL NUTRIENTS, EXCHANGEABLE CATIONS, AND RATIOS DIFFERENTLY (ALTHOUGH NOT STATISTICALLY SIGNIFICANT)}

Although there were very few statistically significant differences found between treatments and their effects on soil response factors, this project did show trends (Table 
8 and 9). In both the compost and cover cropped areas (compared to the control section), at both vineyards, soil $\mathrm{P}$ and $\mathrm{K}$ increased. In addition, soil $\mathrm{OM}$ and $\mathrm{C} / \mathrm{N}$ ratios increased at both vineyards and in all areas. Calcium to magnesium ratios also increased positively in almost all areas at both vineyards.

\begin{tabular}{|c|c|c|c|c|c|c|c|}
\hline Treatment & $\underset{\text { (units) }}{\text { pH }}$ & $\underset{(p p m)}{P}$ & $\begin{array}{c}\mathrm{K} \\
\text { exch } \\
\text { (ppm) }\end{array}$ & OM (\%) & & $\begin{array}{l}\text { Mg } \\
\text { tio }\end{array}$ & $\begin{array}{c}\mathbf{C} / \mathbf{N} \\
\text { Ratio }\end{array}$ \\
\hline Control/Till & $\uparrow 3 \% \uparrow$ & $18 \%$ & $\downarrow 3 \% \uparrow$ & $10 \%$ & $\uparrow$ & $4 \%$ & $\uparrow 21 \%$ \\
\hline Compost/till & $\uparrow 7 \% \uparrow$ & $143 \%$ & $\circ \uparrow 33 \% \uparrow$ & $55 \%$ & $\downarrow$ & $9 \%$ & $\uparrow 84 \%$ \\
\hline Compost/no-till & $-0 \% \uparrow$ & $50 \%$ & $\circ \uparrow 9 \% \uparrow$ & $27 \%$ & $\downarrow$ & $6 \%$ & $\uparrow 33 \%$ \\
\hline Cover Crop/till & $\uparrow 5 \% \downarrow$ & $10 \%$ & $\downarrow 11 \% \uparrow$ & $5 \%$ & $\uparrow$ & $37 \%$ & $\uparrow 5 \%$ \\
\hline Cover Crop/no-till & $\uparrow 1 \% \uparrow$ & $14 \%$ & $\downarrow \downarrow 2 \% \uparrow$ & $17 \%$ & $\uparrow$ & $11 \%$ & $\uparrow 30 \%$ \\
\hline
\end{tabular}

\begin{tabular}{|lccccccc|}
\hline \multicolumn{7}{|c|}{ Table 9. Vineyard Two Soil Nutrient Content Post Treatment in } \\
Percentages
\end{tabular}

Any natural addition (in most cases) of nutrients to the soil through the incorporation of cover crop or compost can be viewed as a good thing. As, the addition of nutrients through conventional methods (i.e. synthetic fertilizers, etc.) can have negative consequences as previously discussed.

\section{SIGNIFICANT DIFFERENCE BETWEEN A FEW BLOCKS WITHIN VINEYARDS AND THEIR MEAN ORGANIC MATTER, CARBON AND NITROGEN CONTENT}

The significant difference found between a few blocks nested within the vineyards and their mean $\mathrm{OM}$ and organic $\mathrm{C}$ and $\mathrm{N}$ concentrations, basically meant that 
there was variability between a few blocks nested within a vineyard. This was a random effect and was only added to the model to add to the larger picture and to add variability. Because there were no trends and the fact that this couldn't be seen at both vineyards, meant that blocking added little to the project.

\section{SIGNIFICANT DIFFERENCE BETWEEN SUB-BLOCKS WITHIN BLOCKS AND THEIR MEAN NUTRIENT, EXCHANGEABLE CATION AND RATIO CONTENT}

There was some statistical affect from different sub-blocks (A or B) nested within blocks on a majority of the soil nutrients, exchangeable cations and ratios (accept organic $\mathrm{C}$ and the $\mathrm{Ca} / \mathrm{Mg}$ ratio). However, because the difference between sub-blocks was different at each vineyard and was not always consistent (i.e., soils from Sub-block A were not always higher in a constituent than those from Sub-block B) and the lack of noticeable trend, meant that effect of slope did not play a role in nutrient concentration in this project.

\section{PHOSPHORUS AND POTASSIUM CONCENTRATIONS INCREASED IN ALMOST ALL TREATMENT AREAS}

Increased soil $\mathrm{P}$ and $\mathrm{K}$ concentrations were expected as the compost added contained $2,000 \mathrm{mg} / \mathrm{Kg} \mathrm{P}$ and $9,200 \mathrm{mg} / \mathrm{Kg} \mathrm{K}$ by dry weight. This was consistent with other researchers who found significant increases $(P=0.05$ or greater) in $P$ and $K$ with cover crops (Smith et al., [2008], Morlat \& Jacquet [2003], and Andrews et al., [2002]). However, many of these studies were conducted over several years, where as this project was conducted over a one-year period. This probably added to the lack of significant increase. 
The increases in $\mathrm{P}$ at both vineyards, and in almost all treatment areas, was a positive thing as it brought the soils closer to the optimum levels required at a vineyard. Over time, the addition of cover crop and compost could help meet the P requirements.

The increase in $\mathrm{K}$ at Vineyard One did not do much for the soil as it already had high concentrations of $\mathrm{K}$ required for vineyard soil. However, at Vineyard Two the increase in $\mathrm{K}$ was a positive thing as it brought the soils closer to the required amount of K necessary for vineyard soils. Three of the four treatment areas had large enough increases in $\mathrm{K}$ to bring them to have either marginal or adequate levels of soil $\mathrm{K}$. Again, over time, the incorporation of cover crop and compost could bring the $\mathrm{K}$ concentrations high enough to be considered adequate.

\section{ORGANIC MATTER INCREASED AT BOTH VINEYARDS AND IN ALL TREATMENT AREAS}

The increase in OM at both vineyards was expected as the compost added contained $39 \%$ OM by dry weight. In addition, other researchers found an increase in OM due to the addition of cover crop (Steenwerth \& Belina [2008], Smith, et al., [2008], and Vavoulidou, et al., [2006]).

The increase in OM at both vineyards was considered a positive effect because

of the many benefits associated with OM. Although the applied rate of three tons/acre (6000 lbs/ac) of compost was not much, if it were applied every year, OM could increase significantly.

\section{C/N RATIOS INCREASED WITH ALL TREATMENTS}

The increase in $\mathrm{C} / \mathrm{N}$ ratios was expected as compost contains decomposed plant material. The compost added contained a $14: 1 \mathrm{C} / \mathrm{N}$ ratio by dry weight. In addition, 
other researchers have found an increase in OM due to the addition of cover crop (Veenstra et al., [2006], Wienhold and Halvorson [1998], and Hepperly et al., [2008]).

The increases of $\mathrm{C} / \mathrm{N}$ ratios at both vineyards was seen as positive thing. Although no guidelines ${ }^{9}$ for vineyard soil $\mathrm{C} / \mathrm{N}$ ratios could be found during the course of the project, typical $\mathrm{C} / \mathrm{N}$ ratios between 10:1 and 20:1 are considered ideal. Since both vineyards had $\mathrm{C} / \mathrm{N}$ ratios between 10 and 20 , the increase meant a beneficial addition of carbon and nitrogen, $\mathrm{OM}$, and nutrients for microbial consumption.

\section{ADDING COVER CROP OR COMPOST IS BENEFICIAL TO THE SOIL}

Adding cover crop or compost is beneficial to the soil because it is a natural addition versus a synthetic one, as was seen by the increase in soil nutrients $\mathrm{P}$ and $\mathrm{K}$, $\mathrm{OM}, \mathrm{Ca} / \mathrm{Mg}$ and $\mathrm{C} / \mathrm{N}$ ratios. Soil $\mathrm{P}$ increased in the compost and cover crop areas between 12 to $143 \%$ compared to the control areas, which increased by $18 \%$ at Vineyard One and decreased by $15 \%$ at Vineyard Two. Soil K concentrations increased between 9 to $78 \%$ in the compost and cover crop areas whereas $\mathrm{K}$ concentrations decreased in the control areas (Vineyard One 3\%, Vineyard Two 18\%). Organic matter increased at a max of $55 \%$ in the compost and cover crop areas versus the control areas, which only increased by 10 and $25 \%$. Soil $\mathrm{Ca} / \mathrm{Mg}$ ratios increased positively in the treatment areas between 8 to $43 \%$ and only $4 \%$ in the control area at Vineyard One. The control area at Vineyard Two saw a decrease in the $\mathrm{Ca} / \mathrm{Mg}$ ratio by $31 \%$. Soil $\mathrm{C} / \mathrm{N}$ ratios increased (in a positive manner) in all treatment areas at a max of $84 \%$, the control areas increased by 15 and $21 \%$.

\footnotetext{
${ }^{9}$ No vineyard optimum $\mathrm{C} / \mathrm{N}$ ratios could be located by the author during the course of the project.
} 
At the Jefferson Memorial in Washington there is a quote on the wall that states "Soil is God's Gift to the Nation" (Paul and Kimble, 2009). We know that it affects plant, animal and human health, as well as nearby natural resources. As such, it is our duty to protect and preserve it. Sustainability is one way grower's can help do this. Through the implementation of sustainable management practices, such as cover crops, compost and reduced till, growers can reduce the amount of fertilizers and pesticides applied, restore the nutrients in the soil and enhance the microbial activity. 


\section{BIBLIOGRAPHY}

AgQuest Consulting, Inc. 2000. Vineyard Suitability Study Bassi Property - Avila, California.

Andrews, S.S., J.P. Mitchell, R. Mancinelli, D.L. Karlen, T.K. Hartz, W.R. Horwath, G.S. Pettygrove, K.M. Scow, and D.S. Monk. 2002. "On-Farm Assessment of Soil Quality in California Central Valley." Agron. J. 94:12-23.

Battany, M. 2008. Personal communication.

Biradar, D.P., K.S. Shivakumar, S.S. Prakash and B.T. Pujar. 2006. "Bionutrient Potentiality of Parthenium hysterophorus and its Utility as Green Manure in Rice Ecosystem." Karnataka J. of Agric. Sci. 19:(2):256-263.

Bugg, R.L., 2008. Personal correspondence.

California Fertilizer Association. 1995. Western fertilizer handbook. Danville, Illinois: Interstate Publishers.

Campbell, C.A., V.O. Bierderbeck, R.P. Zentner, and G.P. Lafond. 1991. "Effect of crop rotations and cultural practices on soil organic matter, microbial biomass and respiration in a thin Black Chernozem." Can. J. of Soil Sci. 71:363-376.

Carpenter, J. 2009. Personal correspondence.

Clark, M. Sean, W.R. Horwath, C. Shennan, and K.M. Scow. 1998. "Changes in Soil Chemical Properties Resulting from Organic and Low-Input Farming Practices." Agron. J. 90:662-671.

Coombe, B. and P. Dry. 1988. Viticulture, Vol 1: Resources. Adelaide:Winetitles.

Coombe, B. and P. Dry. 1992 Viticulture, Vol 2: Practices. Adelaide:Winetitles.

Daane, Kent M. 2008. Personal correspondence.

De Gryze, S., M.V. Albarracin, R. Catala-Luque, R.E. Howitt and J. Six. 2009. "Modeling shows that alternative soil management can decrease greenhouse gases." Calif. Agric. 63:2 April/June. Retrieved July 28, 2009 (http://CaliforniaAgriculture.ucop.edu).

Dingus, D. 2009. Personal communication.

Doran, J.W. 2002. "Soil health and global sustainability: translating science into practice." Agric. Ecosyst. and Environ. 88:119-127. (Retrieved from ScienceDirect on October 14, 2008).

Doran, J.W. and A.J. Jones. 1996. Methods for Assessing Soil Quality. SSSA Special Publication Number 49. Madison, WI: SSSA. 
Doran, J.W. and T.B. Parkin. 1996. "Quantitative Indicators of Soil Quality." p. 25-37. In J.W. Doran and A.J. Jones (ed.) Methods for assessing soil quality. SSSA Spec. Publ. 49. Madison, WI:SSSA.

Drinkwater, L.E., P. Wagoner and M. Sarrantonio. 1998. "Legume-based cropping systems have reduced carbon and nitrogen losses." Nature 396:262-265.

Faber, B. 1999. "Lemon Orchard Mulch and Cover Crop Trial." Progress Report, University of California Cooperative Extension, Ventura-Santa Barbara Counties.

Fließbach, A., H. Oberholzer, L. Gunst, and P. Mäder. 2007. "Soil organic matter and biological soil quality indicators after 21 years of organic and conventional farming." Agric. Ecosyst. and Environ. 118:273-284.

Frances, C.A., R.P. Poincelot, and George W. Bird. 2006. Developing and Extending Sustainable Agriculture A New Social Contract. New York: Haworth Food \& Agriculture Products Press.

Francis, H. 2008. Personal correspondence.

Gardner, J.C. and S.A. Clancy. 1996. "Impact of Farming Practices on Soil Quality in North Dakota." p. 337-343. In J.W. Doran and A.J. Jones (ed.) Methods for assessing soil quality. SSSA. Special Publication 49. SSSA, Madison, WI.

Gomez, A.A., D.E. Swete Kelly, J.K. Syers, and K.J. Coughlan. 1996. "Measuring Sustainability of Agriculture Systems at the Farm Level." In J.W. Doran and A.J. Jones (ed.) Methods for assessing soil quality. SSSA Spec. Publ. 49. SSSA, Madison, WI.

Grant, S. 2002. "Balanced soil fertility management in wine grape vineyards." Practical Winery and Vineyard. May/June, pp. 1-7

Hanson, A. and J. Gach. 2008. The Mulch Comparing Synthetic vs. Organic Fertilizers. Blue Ridge Vermiculture. Retrieved on July 10, 2008 (http//www.themulch.com)

Heald, E. and R. 2009. "Paso Robles emerges as a Rhone Zone." Practical Winery and Vineyard. January/February, pp. 1-5.

Hepperly, P. 2008. Personal correspondence.

Hepperly, P. and C.Z. Ulsh. 2007. "Studies and Advances in Composting Technology." Acres U.S.A. 37(9). September.

Hepperly, P.R., D. Douds Jr. and R. Seidel. 2008. The Rodale Institute Farming Systems Trial 1981 to 2005: Long-term analysis of organic and conventional maize and soybean cropping systems. Found in: ISOFAR Long Term Field Ex 10, 2008 (periments in Organic Farming 2008.

Ingels, C. 1992. Technical Brief - "Sustainable Agriculture and Grape Production." Amer. J. Enol. and Vit. 43(3). 
Ingels, C.A. and K.M. Klonsky. 1998. "Historical and Current Uses." Pp. 3-8 in Cover Cropping in a Vineyard a Grower's Handbook. University of California: Publication 3338.

Jackson, L.E., I. Ramirez, R. Yokota, S.A. Fennimore, S.T. Koike, D.M. Henderson, W.E. Chaney, and K.M. Klonsky. 2003. "Scientists, growers assess trade-offs in use of tillage, cover crops and compost." Calif. Agric. 57(2):48-54.

King, A.P., and A.M. Berry. 2005. "Vineyard X15N, nitrogen and water status in perennial clover and bunch grass cover crop systems of California' central valley." Agric. Ecosyst. and Environ. 109:262-272. (Retrieved from ScienceDirect on November 10, 2008.)

Köster, V. Dr. 2008. Personal correspondence.

Lambert, J., M.M. Anderson, and J.A. Wolpert. 2008. "Vineyard nutrient needs vary with rootstocks and soils." Calif. Agric. 62(4) October/December. Retrieved July 28, 2009 (http://CaliforniaAgriculture.ucop.edu)

Lessard, C. 2009. Personal communication.

Lindsey, J. 2009. Personal correspondence.

Lodi-Woodbridge Winegrape Commission. 2000. Sustainable Agriculture. Lodi Winegrowers Workbook. Lodi, CA.

Lundquist, E. 2008. "High Magnesium Soils." Lake County Winegrape Organization. Retrieved July 28, 2009 (www.lakecountywinegrape.org/growers/nt-highmag.php)

Mäder, P. 2008. Personal correspondence.

Mäder, P., A. Fließbach, D. Dubois, L. Gunst, P. Fried, and U. Niggli. 2002. "Soil Fertility and Biodiversity in Organic Farming." Sci. 296. May 2002.

Majumder, B., B. Mandal, A. Gangopadhyay, P.K. Mani, and D. Mazumbar. 2008. "Organic Amendments Influence Soil Organic Carbon Pools and Rice-Wheat Productivity." SSSAJ 72(3) May-June.

McCallum, K.R., A.A. Keeling, C.P. Beckswith and P.S. Kettlewell. 1998. "Effects of Green Waste Compost on Spring Wheat (Triticum Aestivum L. CV Avans) Emergence and Early Growth." Acta horticulturae 469:313 -318.

McGourty, G. 2004. "Cover cropping systems for organically farmed vineyards." Practical Winery and Vineyard. September/October.

Morlat, R. and A. Jacquet. 2003. "Grapevine Root System and Soil Characteristics in a Vineyard Maintained Long-term with or without Interrow Sward." Am. J. Enol. Vitic. 54(1):1-7. 
O'Green, A., S. Pettygrove, R. Southard, H. Minoshima, and P.S. Verdegaal. 2008. "Soil-landscape model helps predict potassium supply in vineyards." Calif. Agric. 62(4) October/December. Retrieved July 28, 2009 (http://CaliforniaAgriculture.ucop.edu)

Oquist, K.A., J.S. Strock, and D.J. Mulla. 2006. "Influence of Alternative and Conventional Management Practices on Soil Physical and Hydraulic Properties." Vad. Zone J. 5:356-364.

Paul, E.A. and J. Kimble. 2009. "Global Climate Change: Interactions with Soil Properties." $\quad$ Retrieved September $\quad 19,2009$ (http://www.usgcrp.gov/usgcrp/nacc/agriculture/paul.pdf)

Pickering, J.S., A.D. Kendle, and P. Hadley. 1998. "The Suitability of Composted Green Waste as an Organic Mulch: Effects on Soil Moisture Retention and Surface Temperature." Acta horticulturae 469:319 -324.

Pretty, J. 2008. "Agriculture sustainability: concepts, principles and evidence." Landwards 63:17-19. Bedford, England: Institution of Agriculture Engineers.

Raupp, J., C. Pekrun, M. Oltmanns and U. Kopke. 2006. Long-term Field Experiments in Organic Farming. International Society of Organic Agriculture (ISOFAR), Scientific Series.

Reeve, J.R., L. Carpenter-Boggs, J.P. Reganold, A.L. York, G. McGourty, and L.P. McCloskey. 2005. "Soil and Winegrape Quality in Biodynamically and Organically Managed Vineyards.” Am. J. Enol. Vitic. 56(4)367-376.

Rice, T.J. 1999. "Liming of Vineyard Soils." Practical Winery and Vineyard. July/August. Retrieved July 28, 2009 (www.practicalwinery.com/julyapr99/liming.htm)

Saxton, V. 2002. "Calcium in Viticulture Unravelling the mystique of French Terroir." Wine Business Monthly. September 10. Retrieved July 28, 2009 (http://www.winebusiness.com/wbm/?go=getArticle\&datald=20182)

Scholfield, T. 2008. "Sustainable farming practices." Landwards Magazine. Spring.

Scow, K.M., O. Somasco, N. Gunapala, S. Lau, R. Venette, H. Ferris, R. Miller, C. Shennan. 1994. "Transition from conventional to low-input agriculture changes soil fertility and biology." Calif. Agric. 48(5).

Seger, P. 2009. Personal communication.

Smith, P. and D.S. Powlson. 2008. Chapter 13 - Sustainability of Soil Management Practices - A Global Perspective. Found on the UC Sustainable Ag Research and ED. Program website on October 14, 2008.

Smith, R., L. Bettiga, M. Cahn, K. Baumgartner, L.E. Jackson, and T. Bensen. 2008. "Vineyard floor management affects soil, plant nutrition, and grape yield and quality." Calif. Agric. 62(4):184-190. 
Stamatiadis, S., A. Liopa-Tsakalidi, L.M. Maniati, P. Karageorgou, and E. Natioti. 1996. "A Comparitive Study of Soil Quality in Two Vineyards Differing in Soil Management Practices." p. 381-391. In J.W. Doran and A.J. Jones (ed.) Methods for assessing soil quality. SSSA Spec. Publ. 49. SSSA, Madison, WI.

Steenwerth, K. and K.M. Belina. 2008. "Cover crops enhance soil organic matter, carbon dynamics and microbial function in a vineyard agroecosystem." App. Soil Ecol. 40:359369. (Retrieved from ScienceDirect on November 10, 2008.)

Stimson, D. 2005. "Multiple benefits in vineyard erosion control." Practical Winery and Vineyard Magazine. January/February.

Tilman, D. 1999. "Global environmental impacts of agricultural expansion: the need for sustainable and efficient practices." Proc. Natl. Aca. Sci. USA 96, 5995-6000.

USDA. 1984. Soil Survey of San Luis Obispo County, California coastal part. Soil Conservation Service.

USDA. 2009. Sustainable Agriculture: Definitions and Terms. Retrieved June 20, 2009 (http://www.nal.usda.gov/afsic/pubs/terms/srb9902.shtml\#toc1)

Vavoulidou, E., E.J. Avramides, A. Dimirkou, and P. Papadopoulos. 2006. "Influence of Different Cultivation Practices on the Properties of Volcanic Soils on Santorini Island, Greece." Comm. Soil Sci. Plant Anal. 37:2857-2866.

Veenstra, J.J., W.R. Horwath, J.P. Mitchell, and D.S. Munk. 2006. "Conservation tillage and cover cropping influence soil properties in San Joaquin Valley cotton-tomatoe crop." Calif. Agric. 60(3):146-153.

White, R.E. 2003. Soils for Fine Wines. New York:Oxford University Press, Inc.

Walter-Peterson, H. 2008. Nutrient Value of Compost in Vineyards. VA Tech. Retrieved July 28, 2009 (http://www.vaes.org.vt.edu/AHSMITHJAREC/Compost Use in Vineyards_For Web Publication).

Wheeler, L.E. and P.D. Brown. 1999. "Gypsum injection into vineyard drip systems." Practical Winery and Vineyard. Retrieved July 28, 2009 (www.practicalwinery.com/marapr99/gypsum.htm).

Wienhold, B.J. and A.D. Halvorson. 1998. "Cropping System Influences on Several Soil Quality Attributes in the Northern Great Plains." J. of Soil and Water Cons. 53(3)254258.

Yield Wine Bar. 2008. Sustainable Viticulture. Retrieved October 10, 2008 (http://www.yieldsf.com/_Yield_Wine_Bar_Eco-Friendly_Wine.html) 


\section{APPENDICES}

A VINEYARD ONE SOIL PROFILE DESCRIPTION 


\section{B COMPOST LAB ANALYSIS}


C ORIGINAL SOIL LAB DATA 